\title{
A high-resolution ${ }^{40} \mathrm{Ar} /{ }^{39} \mathrm{Ar}$ lava chronology and edifice construction history for Ruapehu volcano, New Zealand
}

Chris E. Conway $^{1}{ }^{*}$, Graham S. Leonard ${ }^{2}$, Dougal B. Townsend ${ }^{2}$, Andrew T. Calvert ${ }^{3}$, Colin J. N. Wilson ${ }^{1}$, John A. Gamble ${ }^{1}$, Shaun R. Eaves ${ }^{1}$

${ }^{1}$ School of Geography, Environment and Earth Sciences, Victoria University of Wellington, PO Box 600, Wellington 6140, New Zealand

${ }^{2}$ GNS Science, 1 Fairway Drive, Avalon, PO Box 30-368, Lower Hutt 6315, New Zealand

${ }^{3}$ US Geological Survey, 345 Middlefield Road, MS-937, Menlo Park, CA 94025, USA

* Corresponding author: conwaychri@myvuw.ac.nz

Keywords: Ruapehu, Ar/Ar dating, composite volcano, eruptive history, glaciovolcanism, andesite volcanism 


\section{ABSTRACT}

Ruapehu is an active $\sim 150 \mathrm{~km}^{3}$ andesite-dacite composite volcano located at the southern end of the Taupo Volcanic Zone, New Zealand. The growth of the present-day edifice has occurred throughout coeval eruptive and glacial histories since $200 \mathrm{ka}$. We present highprecision ${ }^{40} \mathrm{Ar} /{ }^{39} \mathrm{Ar}$ eruption ages for 46 samples and whole-rock major element geochemical data for 238 samples from lava flows. These new plus existing data are interpreted in the context of geomorphologic and geologic mapping, volcano-ice interaction processes and glacier reconstructions to present an improved chronostratigraphic framework and new edifice evolution history for Ruapehu. Sub-glacial to ice-marginal effusive eruption of medium-K basaltic-andesites and andesites constructed the northern portion of the exposed edifice between 200 and $150 \mathrm{ka}$, and a wide southeast planèze as well as parts of the northern, eastern and western flanks between $~ 160$ and $80 \mathrm{ka}$. None of the dated lava flows have ages in the range of $80-50 \mathrm{ka}$, which may reflect an eruptive hiatus. Alternatively the hiatus may be the result of erosion and burial of lavas and syn-eruptive glacial conveyance of lava flows to the ring-plain during glacial advance at 70-60 ka. From $\sim 50-15$ ka edifice growth occurred via effusive eruptions onto the glaciated flanks of the volcano, resulting in construction of ice-bounded planèzes and ridges. The distribution of dated ice-marginal lavas indicates a general decrease in glacier thicknesses over this time, except for a short-lived period centred at $\sim 31 \mathrm{ka}$ when peak ice cover was reached. The compositional ranges of medium- to high-K andesite and dacite lava flows within 50-35 ka eruptive packages define broadly bimodal high- and low-MgO trends. Lavas erupted at 35-22 ka have compositions that fill a transitional geochemical field between older dacites and younger andesites. Largescale retreat of flank glaciers since $\sim 15 \mathrm{ka}$ has resulted in intra-valley lava flow emplacement at elevations below $\sim 1500 \mathrm{~m}$ on the edifice. Between 15 and $10 \mathrm{ka}$ unstable cones were constructed through effusive activity in the presence of remnant summit and upper flank 
glaciers and the emplacement of eruptive deposits on top of hydrothermally altered and fragmental sub-glacial and ice-marginal deposits. Debuttressing of two northern summit cones and a southern summit cone as ice underwent continued post-glacial retreat preconditioned the edifice for two major sector collapses. Ultimate triggering of the collapse events and deposition of debris avalanche deposits on the northern and south-eastern flanks may have been the result of tectonic or volcanic activity. The northern collapse scar is infilled by a new cone comprising <10 ka lava flows that form the upper northern and eastern flanks of the modern edifice. Late Holocene-Recent eruptive activity has occurred through Crater Lake, which occupies the site of the collapsed southern cone. Deglaciation did not induce enhanced magma flux rates at Ruapehu as indicated by calculated eruptive volumes and their chronologies. However, volcano-ice interactions have had a fundamental influence on eruptive styles, sector collapse events, and the shape of the edifice by modifying the distribution, morphology and preservation of eruptive deposits for at least $200 \mathrm{kyr}$.

Our approach to integrating field and geochronological datasets from Ruapehu is directly relevant to the evolution of glaciated Quaternary composite cones worldwide, particularly those along the circum-Pacific continental volcanic arcs.

\section{Introduction}

Continental composite volcanoes are the archetypical surficial features of convergent margin magmatism where volcanic products are erupted, often in proximity to human populations. Sequences of lavas generally provide the best preserved record of volcanic edifice growth and allow investigation of the tempo of eruptive activity in such settings. High-resolution eruptive records constrained by precise temporal frameworks are required in order to document the stratigraphies of such volcanoes. These records underpin hazard assessment and enhance the value of geochemical and petrological datasets that inform evolutionary 
models of arc magma systems (e.g. Hildreth and Lanphere, 1994; Dungan et al., 2001). The ${ }^{40} \mathrm{Ar} /{ }^{39} \mathrm{Ar}$ radioisotopic system is a widely used geochronometer for measuring the eruption ages of Quaternary volcanic rocks with intermediate compositions (e.g. Gamble et al., 2003; Hildreth et al., 2003a; Fierstein et al., 2011). Despite its general suitability, however, application of this technique has generally been restricted to Pleistocene volcanic rocks with adequate $\mathrm{K}_{2} \mathrm{O}$ concentrations ( $>1$ wt. \%) and non-glassy groundmass textures. High-precision instrumentation (Coble et al., 2011), improved understanding of the behaviour of argon in volcanic glass (Clay et al., 2015), and development of methods to counter argon recoil processes that affect samples from fine-grained rocks (Fleck et al., 2014) have increased the potential for this technique to be applied to Holocene lavas. Despite these advances, incomplete exposure of volcanic edifices often remains a hindrance to establishing comprehensive and cohesive eruptive chronologies. Glaciation and sector collapse are agents of erosion and edifice destruction that not only generate exposure, but also stratigraphic unconformities that inhibit the accurate reconstruction of eruptive events and volumes for composite volcanoes (e.g. Singer et al., 1997). The recognition and integration of volcano-ice interactions within eruptive stratigraphies of glaciated volcanoes is thus crucial to unravelling their evolution (Schmidt and Grunder, 2009). Moreover, deposits resulting from volcano-ice interactions can provide powerful paleoclimate proxies when paired with precise geochronology (e.g. Lescinsky and Fink, 2000; Mee et al., 2009).

In this contribution, new high-precision ${ }^{40} \mathrm{Ar} /{ }^{39} \mathrm{Ar}$ ages and whole-rock major element geochemistry for lava flows are integrated with geological mapping, glacier reconstructions and existing chronostratigraphic studies in order to detail the mid-Pleistocene to Holocene evolution of Ruapehu as a case study of typical arc volcanism. Three key shortcomings of previous research have precluded the generation of a detailed eruption and edifice evolution history for Ruapehu volcano: 
(1) oversight of the effects of syn-eruptive lava-ice interaction on the preservation and distribution of eruptive products;

(2) geochronology data were too sparse to constrain the timing and duration of periods of effusive growth of the volcano; and

(3) fragmentary sampling of the edifice.

The net result of these limitations is that the existing studies of edifice growth (Hackett and Houghton, 1989) and magma system evolution (Price et al., 2012) at Ruapehu rely on an incomplete chronostratigraphic framework.

These issues are pertinent to studies of other high-altitude composite volcanoes located at temperate latitudes that have been affected by multiple periods of glaciation throughout their eruptive histories (e.g. Hobden et al., 1996; Singer et al., 1997; Frey et al., 2004). Ruapehu therefore provides an excellent case study for investigating the ice-affected construction of a Quaternary composite volcano. The foremost purpose of this contribution is to present a highprecision ${ }^{40} \mathrm{Ar} /{ }^{39} \mathrm{Ar}$ lava flow chronology and edifice evolution history for New Zealand's largest active composite volcano. The revised lava chronology is used here to address six key concepts: (1) the applicability of ${ }^{40} \mathrm{Ar} /{ }^{39} \mathrm{Ar}$ dating to Holocene andesite lavas; (2) the potential for ice-bounded lavas to provide paleoclimate information; (3) the effect of lava flow preservation and exposure biases on the completeness of volcanic stratigraphies due to glacial erosion; (4) the compositional evolution of lavas erupted throughout the lifetime of a polygenetic volcano; (5) the role of deglaciation since 20 ka in triggering Holocene sector collapse events; and (6) estimating the long-term eruption rates of composite volcanoes.

\section{Geologic setting}

\subsection{Regional geology}


Volcanism in central North Island, New Zealand, is associated with westward subduction of oceanic crust of the Pacific Plate at $\sim 45 \mathrm{~mm} \mathrm{yr}^{-1}$ beneath the Australian Plate along the Hikurangi Trench system (Fig. 1; Cole and Lewis, 1981; Reyners et al., 2006; DeMets et al., 2010). Most arc-related volcanism is manifested in the Taupo Volcanic Zone (TVZ), a rifting arc active since $2 \mathrm{Ma}$, which comprises northern and southern segments dominated by andesite-dacite composite cones and a rhyolite-dominated central segment (Wilson et al., 1995). The southern TVZ segment comprises the prominent Tongariro and Ruapehu composite volcanoes as well as several smaller inactive volcanic edifices, which collectively form the Tongariro Volcanic Centre (Fig. 1; Cole, 1978). Rifting and extension in the southern TVZ occurs at a direction of $\sim 115^{\circ}$ and a rate of $2.3 \pm 1.2 \mathrm{~mm}$ yr-1 (Villamor and Berryman, 2006a). This motion is manifested by the $40 \mathrm{~km}$-wide Mount Ruapehu graben, which is bounded by the Rangipo and Raurimu faults to the east and west, respectively, and by the NE-striking Karioi and the ENE-striking Ohakune fault sets to the south (Fig. 1; Villamor and Berryman, 2006b). Ruapehu volcano sits on late Tertiary sediments and Mesozoic basement rocks ('greywacke'). The latter are generally inferred to be part of the Kaweka Terrane, a Jurassic greywacke-argillite sequence of felsic composition that outcrops in the ranges east of the Rangipo Fault (Adams et al., 2009; Lee et al., 2011; Price et al., 2015). An index map of Ruapehu with geographical features referred to throughout the text is provided in Fig. 2.

\subsection{Volcanological overview}

Ruapehu is New Zealand's largest active andesite volcano, with a $\sim 150 \mathrm{~km}^{3}$ edifice surrounded by a volcaniclastic ring plain of similar volume (Hackett and Houghton, 1989; Gamble et al., 2003). The flanks of the edifice are composed of lava flows and autobreccias 
intercalated with glacial and pyroclastic deposits (Cole, 1978). Cone-forming lavas and autobreccias were grouped by Hackett (1985) into four formations that represent the eruptive products of four main phases of edifice growth. From oldest to youngest, these formations are the Te Herenga, Wahianoa, Mangawhero and Whakapapa. Their ages and durations were constrained by Gamble et al. (2003) who reported ${ }^{40} \mathrm{Ar} /{ }^{39} \mathrm{Ar}$ eruption ages for lava flows from the Te Herenga (250-180 ka; 3 samples), Wahianoa (160-115 ka; 11 samples) and Mangawhero (60-15 ka; 7 samples) formations (Table 1). Gamble et al. (2003) concentrated on the clear stratigraphic sequencing of lava flows within the Wahianoa Formation exposed in the deeply incised Wahianoa and Whangaehu valleys on the southeast flank of Ruapehu (Fig. 2). Lavas of the Mangawhero Formation were inferred to have been erupted during discrete pulses of effusive activity centred on $\sim 45 \mathrm{ka}$ and $\sim 22 \mathrm{ka}$. In contrast, no ${ }^{40} \mathrm{Ar} /{ }^{39} \mathrm{Ar}$ ages were determined for lavas of the Whakapapa Formation (Gamble et al., 2003), which were assigned a post-glacial age (i.e. <15 ka; Hackett and Houghton, 1985). . However, tephrostratigraphic relationships have provided key age constraints for some lava flows of the Whakapapa Formation (Price et al., 2012). Complex stratigraphic relationships between lavas have previously been interpreted as the result of rapid transitions between construction and degradation of the edifice (Hackett and Houghton, 1989).

The Ruapehu ring plain comprises a thick apron of stacked pyroclastic and volcaniclastic materials consisting of debris flow, debris avalanche and hyperconcentrated stream flow deposits interbedded with local andesitic and distally-derived rhyolitic tephras (Cronin and Neall, 1997; Donoghue and Neall, 2001; Tost et al., 2014). Aggradation has likely been rapid following eruptive phases (Hackett and Houghton, 1989) and during glacial periods (Cronin and Neall, 1997), while large-scale sector collapse events may have occurred following the transition from glacial to interglacial periods (Tost et al., 2015). Explosive activity at Ruapehu since $\sim 27 \mathrm{ka}$ is recorded within tephra sequences on the eastern flank and ring plain 
(Donoghue et al., 1995). During the period from 22-10 ka, the largest known Plinian eruptions occurred at Ruapehu (Pardo et al., 2012), and apparently coeval but volumetrically minor pyroclastic flow deposits are preserved on the eastern flank of the edifice (Donoghue et al., 1995). The past 2 kyr of volcanic activity at Ruapehu have been characterised by lowvolume $\left(<0.05 \mathrm{~km}^{3}\right)$ but frequent $(25-30 \mathrm{yr}$ periodicity) phreatomagmatic eruptions through Crater Lake (Donoghue et al., 1997) with additional phreatic eruptions occurring as often as annually (Houghton et al., 1987).

Past glaciation of Ruapehu is evident from the deep U-shaped valleys that indent the flanks of the edifice (Fig. 2) as well as the presence of large lateral moraines and striated lava flow surfaces (McArthur and Shepherd, 1990; Waight et al., 1999). The most recent major glaciation of the edifice occurred between $\sim 31$ and $17 \mathrm{ka}$ (Eaves et al., 2016a), overlapping with the $\sim 20$ ka global Last Glacial Maximum (LGM; Clark et al., 2009), when the termini of valley glaciers reached as low as $\sim 1200 \mathrm{~m}$ a.s.l. The impact of pre-historic glaciation of Ruapehu between phases of eruptive activity was previously recognised as having generated major stratigraphic unconformities (Hackett and Houghton, 1989). The coincidence of emplacement of Mangawhero Formation lavas (60-15 ka) within the last glacial cycle (71-15 ka; Lisiecki and Raymo, 2005) suggests that syn-eruptive interaction between lava and ice was also an important aspect of the edifice growth history. There is widespread evidence for lava-ice interaction during emplacement of flows of the Mangawhero Formation (Spörli and Rowland, 2006; Conway et al., 2015). Glaciers have retreated rapidly in historical times (Heine, 1963), and only sparse accumulations of permanent ice are now present around the uppermost western, southern and eastern flanks, and over the broad ice-filled northern portion of the Summit Plateau (Fig. 2). 


\section{Methods}

\subsection{Field studies and mapping}

Field campaigns were conducted on foot with occasional helicopter assistance throughout the months of January-May from 2012 to 2015 as part of a wider mapping project (Townsend et al., in prep.). The edifice is largely snow-free during these months, and the lack of vegetation above $1500 \mathrm{~m}$ above sea-level (a.s.1.) is advantageous for exposure on the mid- to upper elevation flanks of the volcano. Access is aided by ski fields on the eastern, northern and southern flanks, and the numerous recreational hiking tracks. Stratigraphic and lithological boundaries for eruptive packages were drawn, largely on geomorphologic characteristics tested in the field and later refined by petrological, geochemical and geochronological analyses.

\subsection{Whole-rock analyses by $X$-ray fluorescence}

Samples collected from lava flows were crushed using a Boyd crusher, and powdered using an agate or tungsten-carbide ring mill. Powders were made into fused lithium metaborate glass discs and analysed for major oxide concentrations by X-ray fluorescence spectroscopy (XRF) following the methods of Ramsey et al. (1995). Disc-making and analyses were carried out at the Open University, Milton Keynes, U.K. Internal standards WS-E (Whin Sill dolerite) and OU-3 (Nanhoron microgranite) were analysed once for every 20 sample analyses to monitor precision and accuracy of the results. Major oxide analyses are accurate to within $2 \%$ of the recommended values for the internal standards. Analytical precision $(2 \sigma)$ is better than $2 \%$ for all elements with concentrations $>0.3$ wt. \%. Duplicate disks were made for three different Ruapehu lava sample powders and analysed as unknowns: duplicate 
analyses were accurate to within $5 \%$ of each other for all major elements. Standard data are presented in Electronic Appendix 1.

\section{3. ${ }^{40} \mathrm{Ar}{ }^{39}$ Ar geochronology}

Radiometric ${ }^{40} \mathrm{Ar} /{ }^{39} \mathrm{Ar}$ dating was undertaken using crystalline groundmasses from interior zones of lava flows to produce the most reliable results (e.g. Gamble et al., 2003; Fierstein et al., 2011). Analysis required minimum groundmass plagioclase crystal widths of $10 \mu \mathrm{m}$ (to avoid reactor recoil) and groundmass glass abundances of $<5 \%$ (to minimise any erroneous contribution from glass-derived argon). Samples selected for radiometric dating were crushed and sieved, and the 250-350 $\mu \mathrm{m}$ fraction used for analysis. An LB-1 Barrier type Frantz magnetic separator was used to remove phenocrysts and xenoliths from the pure groundmass fraction. To remove altered and adhered material, groundmass separates were washed in water in an ultrasonic bath and repeatedly decanted for up to 20 hours, washed in acetone to remove any hydrocarbons from grain surfaces, and finally rinsed in deionized water. Any remaining grains with adhering phenocrysts, xenoliths or areas of glass were removed by hand-picking. Encapsulated packets of $\sim 200 \mathrm{mg}$ of groundmass were irradiated for $1 \mathrm{~h}$ in the central thimble of the USGS-TRIGA reactor in Denver, Colorado (Dalrymple et al., 1981). Samples were shielded from thermal neutrons and neutron flux was measured using Taylor Creek Rhyolite sanidine (TCR-2) fluence monitors with an assigned age of 27.87 Ma (M.A. Lanphere, written communication), equivalent to the widely used Fish Canyon sanidine at $27.63 \mathrm{Ma}(\mathrm{R}=1.00881 \pm 0.00046)$. The reactor vessel was rotated continuously during irradiation to minimise any lateral neutron flux gradients. Fluence monitors were analyzed using a continuous laser system and a MAP 216 mass spectrometer described by Dalrymple (1989). Argon was extracted from feldspar separates using a Mo crucible in a Staudacher- 
type custom resistance furnace attached to the MAP 216 mass spectrometer following analytical procedures outlined in Calvert et al. (2005). Heating temperatures were monitored with an optical fibre thermometer and controlled with a LabView PID controller. Gas was purified continuously during extraction using two SAES ST-172 getters operated at 4 A and 0 A.

\section{Eruptive history of Ruapehu}

New and existing geochronological and geochemical data are used here to describe edificeforming eruptive products at Ruapehu. This section is divided in line with the four chronostratigraphic formations defined by Hackett (1985), however, new data are used here to refine the temporal ranges and compositional characteristics of these formations. The Mangawhero and Whakapapa formations are further broken down into eruptive packages that are defined based on the age, location, morphology, petrography and major element composition of lava flows. These packages will be formally classified as stratigraphic members by Townsend et al. (in prep.), where appropriate definition of type localities and characteristics will be presented. The temporal and spatial distribution of the packages is summarised in Fig. 3, and shown in maps in Figs. 4, 9, 10 and 14.

${ }^{40} \mathrm{Ar} /{ }^{39} \mathrm{Ar}$ geochronology data are presented here for 46 lava samples (Table 2), including three ages that were reported in Conway et al. (2015). Total gas, isochron and weighted mean plateau ages (WMPA) were calculated for each sample experiment (see Electronic Appendix 2 for age spectra graphs for all experiments). Total gas ages were calculated from the sums of radiogenic ${ }^{40} \mathrm{Ar}$ and potassium-derived ${ }^{39} \mathrm{Ar}$ in all step-heating increments of the analysis. Isochron ages were calculated from ${ }^{40} \mathrm{Ar} /{ }^{36} \mathrm{Ar}$ versus ${ }^{39} \mathrm{Ar} /{ }^{36} \mathrm{Ar}$ correlation using the algorithm of York (1969). Plateau ages are the inverse-variance weighted means calculated for the steps 
of an age spectrum comprising contiguous gas fractions that represent $>50 \%$ of the total ${ }^{39} \mathrm{Ar}$ released from the sample. Total gas ages are similar to plateau ages (within $2 \sigma$ uncertainty) for nearly all samples. There are 2 exceptions for post-glacial lavas and 4 exceptions for synglacial samples; the difference between plateau and total gas ages in these cases can be explained by the low numbers of heating steps $(n=3-7)$ included in plateau age calculations. The isochron age is preferred as the most suitable eruption age estimate for sample CC545 because the ${ }^{40} \mathrm{Ar} /{ }^{36} \mathrm{Ar}$ intercept is not within $2 \sigma$ error of the atmospheric value. Two experiments resulted in recoil spectra patterns indicative of ${ }^{39} \mathrm{Ar}$ loss during irradiation. To preclude an underestimation of the eruption age due to reduced ${ }^{40} \mathrm{Ar} /{ }^{39} \mathrm{Ar}$ values at high temperature increments, recoil model ages have been calculated from the entire spectra (100\% fraction of ${ }^{39}$ Ar released) of the two affected samples using the method outlined in Fleck et al. (2014).

Time brackets for the formations and eruptive packages are defined by taking into account individual ${ }^{40} \mathrm{Ar} /{ }^{39} \mathrm{Ar}$ ages and their $2 \sigma$ uncertainties for all relevant flows. Major element compositions for formations and eruptive packages are summarised in Table 3 and full data are given in Electronic Appendix 1.

\subsection{Te Herenga Formation (200-150 ka)}

The oldest exposed volcanic products on Ruapehu are medium-K basaltic-andesite dikes, lava flows and volcaniclastic breccias of the Te Herenga Formation that form the eroded remnants of an edifice on the northern flank of Ruapehu (Figs. 4, 5). The timing of this volcanism is constrained by three existing and five new ${ }^{40} \mathrm{Ar} /{ }^{39} \mathrm{Ar}$ ages (Tables 1, 2). The oldest exposed volcanic product dated in this study yielded an imprecise eruption age of $187.9 \pm 34.4 \mathrm{ka}$ (age $\pm 2 \sigma$ error), which is comparable to the existing value of $205 \pm 27 \mathrm{ka}$ for the oldest exposed 
products measured by Gamble et al. (2003). Ruapehu volcano has a lifetime inferred to extend back to at least $340 \mathrm{ka}$ (Gamble et al., 2003). An older limit of $200 \mathrm{ka}$ is used for the Te Herenga Formation here in order to reflect the most precise eruption ages measured for early lavas (Tables 1,2). An age of $186.2 \pm 6.2 \mathrm{ka}$ was measured for the most mafic lava flow sampled from Ruapehu (53.8 wt. \% $\mathrm{SiO}_{2}$; the 'Ruapehu basalt' of Price et al., 2012), which had previously been assigned to the Mangawhero Formation (Hackett, 1985). This flow is one within a series of flows forming the nose of a ridge now preserved $\sim 150 \mathrm{~m}$ above younger deposits (Fig. 5). Three eruption ages and their uncertainties (WMPA $\pm 2 \sigma$ ) bridge the previously interpreted hiatus between 180-160 ka (Gamble et al., 2003) and hence the younger limit of Te Herenga Formation is adjusted here to $150 \mathrm{ka}$. The oldest products on the northern flank of Ruapehu form much of Pinnacle Ridge and are a 100 m-thick unit of monomict volcaniclastic breccias intruded by dikes and quenched lobes of lava exposed at elevations up to $2000 \mathrm{~m}$ a.s.l. (Figs. 5, 6a). Breccia clasts display radial fractures indicative of quench-contraction cooling and are hosted in a palagonitised ash matrix (Fig. 6a). These deposits are interpreted here to represent hyaloclastite breccias that were erupted under ice/meltwater. From the core of Pinnacle Ridge, lava flows and breccias flowed north and are now exposed in deep valleys and along prominent ridges, where they were depositionally impounded by large glaciers (Fig. 5). Breccia units are monomict, enclosed in steep lensoidal packets, range from poorly to moderately sorted with maximum clast sizes of $80 \mathrm{~cm}$, and occasionally display weak bedding and rare lenses of finely laminated ash (Fig. 6b). The distribution of lavas and characteristics of breccias indicate that ice- and meltwater-marginal fragmentation, transportation and emplacement/deposition occurred during emplacement of these products (cf. Hackett and Houghton, 1989; Smith et al., 1999). Te Herenga Formation volcanics are petrographically distinguished from younger lavas by their devitrified groundmass textures and prominent pyroxene glomerocrysts that are 4-12 mm across (Fig. 
6d). The $\mathrm{SiO}_{2}$ contents of Te Herenga Formation lavas range from 54-57 wt. $\%$ and $\mathrm{K}_{2} \mathrm{O}$ contents range from $0.7-0.9$ wt. \%, making them the least evolved eruptives exposed on Ruapehu (Table 3).

\subsection{Wahianoa Formation (166-80 ka)}

Lava flows of the Wahianoa Formation (Hackett, 1985) flowed primarily to the southeast from vents located south of the exposed Te Herenga Formation eruptives. Wahianoa Formation lavas are medium- $\mathrm{K}$ basaltic-andesites and andesites $\left(56-60\right.$ wt. \% $\left.\mathrm{SiO}_{2}\right)$ that exhibit slightly elevated $\mathrm{K}_{2} \mathrm{O}$ contents compared with the earlier Te Herenga Formation lavas (Table 3). The lower boundary (154 $\pm 12 \mathrm{ka}$; Gamble et al., 2003) for the Wahianoa Formation is constrained by the stratigraphically lowest lava flow within the Whangaehu valley. The lava is at the base of a planèze comprised of a 300 m-thick sequence of alternating lava flows, pyroclastic flows and debris flows between the deeply incised Wahianoa and Whangaehu valleys (Figs. 4, 7, 8a). Individual flows within the sequence generally exhibit planar thicknesses of 1-2 m, but occasionally swell into 15 m-thick knuckles indicative of ponding in paleo-topographic depressions, and/or against ice (Fig. 8c). Lavas are intercalated with autobreccias and debris flow deposits on metre scales (Fig. 8c). Wahianoa Formation lava flows are also exposed within the Ohinepango River valley to the northeast and the Mangaturuturu River valley to the west, and beneath younger syn-glacial lavas on the northwest and northern flanks of the volcano (Fig. 4). At the core of the southeastern planèze, a voluminous mound of breccia, intruded by dikes and lava lobes, is inferred to have a subglacial or subaqueous origin. The unit comprises monomict, subangular to sub-rounded clasts displaying radial fractures and quenched rinds that are held in an orange-pink cemented, palagonitized ash matrix, interpreted to be a hyaloclastite breccia 
(Figs. 8a, b). A minimum age constraint of $154 \pm 12 \mathrm{ka}$ for this breccia is provided by the overlying dated lava flows (Gamble et al., 2003). However, an unconformity separates this and other lavas of the southeast planèze from the breccia and may indicate that the latter is significantly older than $\sim 160 \mathrm{ka}$. Comparison of existing and new geochronology data presented for Te Herenga Formation above indicates that coeval effusion may have occurred from northern (Te Herenga) and southern (Wahianoa) vents at 160-150 ka.

New ages of $120.7 \pm 4.0$ and $121.4 \pm 2.8$ ka were determined for flows located at 1400 and $1500 \mathrm{~m}$ a.s.l. on the southeast flank of Ruapehu that correspond to the upper sequence of the Wahianoa Formation as defined by Gamble et al. (2003). A similar sequence is exposed on the northeast flank, with an age of $121.7 \pm 4.2$ ka measured for a flow sampled from the upper true right bank of the Ohinepango Stream valley (Fig. 4). The existing age range for the Wahianoa Formation is extended here to account for lavas that are exposed on the lower northern $(95.9 \pm 7.0 \mathrm{ka})$ and eastern $(88.1 \pm 6.4 \mathrm{ka})$ flanks (Fig. 4). These lavas have very low slope angles, are covered by till, and are located at low elevations within glacially eroded valleys (Fig. 8d). These characteristics indicate that the flows were emplaced onto an edifice that was relatively ice-free during this period, which coincides with part of a previously inferred eruptive hiatus at Ruapehu (Gamble et al., 2003). Despite the disparate distribution of interglacial andesites on southwest, west and northwest flanks, the lavas are interpreted from the petrographic and compositional characteristics to have been sourced from one central magma system contiguous to that which sourced older lavas of the Wahianoa Formation.

\subsection{Mangawhero Formation (50-15 ka)}


The Mangawhero Formation, first defined by Hackett (1985), was interpreted by Gamble et al. (2003) to encompass volcanic products erupted during effusive episodes centred at $\sim 45 \mathrm{ka}$ (based on two lava flow ages) and $\sim 22 \mathrm{ka}$ (based on five lava flow ages). Twenty-five lava flow ages measured for this study span a near-continuous range from $\sim 48-15 \mathrm{ka}$, and are used to redefine the chronological and areal extent of lava flows that comprise this formation. The majority of WMPA $(n=17)$ fall within a period from $\sim 45-38 \mathrm{ka}$. No lava flow ages were detected in the interval between 37 and $31 \mathrm{ka}$, although this period is bridged by $2 \sigma$ uncertainties of the plateau ages for three new samples and one sample from Gamble et al. (2003). The majority of Mangawhero Formation flows display strong evidence for interaction with ice and were emplaced on moraine ridges along the lateral margins of glaciers or dammed behind large volumes of valley-filling ice (Conway et al., 2015). As a result of excellent exposure and optimal groundmass textures for dating, Mangawhero Formation lava flows were sampled extensively, which has enabled the detailed discrimination between the various eruptive packages presented below and in Figs. $9(\sim 50-35 \mathrm{ka})$ and $10(\sim 35-15 \mathrm{ka})$. The packages have been assigned names based on geographic features, which have indigenous Māori names on Ruapehu. These names are the same as those used and formally defined as members by Townsend et al. (in prep.).

\subsubsection{Ngahuinga package (48-35 ka)}

This sequence of andesite flows is exposed on the western and northwestern flanks of the volcano (Fig. 9). The timing of this effusive activity is bounded by an eruption age of $44.8 \pm$ 3.0 ka for the deepest exposed flow. The southern ridge of the Whakapapaiti Stream valley includes a series of at least four individual $\leq 5 \mathrm{~m}$-thick ice-bounded flows (Fig. 11), the 
second-oldest of which yielded an eruption age of $39.6 \pm 2.8 \mathrm{ka}$. On western Ruapehu, an icebounded Ngahuinga package andesite flow was emplaced at $38.3 \pm 3.4 \mathrm{ka}$.

\subsubsection{Mangaehuehu package (47-40 ka)}

The Mangaehuehu package comprises voluminous andesitic lava flows that form the southern portion of the Ruapehu edifice between the Wahianoa and Mangaturuturu river valleys, as well as western parts of the edifice (Figs. 7,9). Eruptions of Mangaehuehu package lavas are tightly constrained between 47 and 40 ka when taking into account all 6 new individual ${ }^{40} \mathrm{Ar} /{ }^{39} \mathrm{Ar}$ WMPA and $2 \sigma$ uncertainties measured for these flows. The eruption age of $47 \pm 4$ ka (and duplicate age of $53 \pm 4 \mathrm{ka}$ ) determined by Gamble et al. (2003, sample R-S44-10) was not used to define the eruptive package age range because of the low number of heating steps used in those analyses.

The flows are defined by distinctly high $\mathrm{MgO}$ contents (and Mg\#-values; Table 3) when compared to other Ruapehu lavas at equal $\mathrm{SiO}_{2}$ contents, which enables undated distal flows to be unambiguously assigned to this package. Lava samples collected from Girdlestone Peak by Hackett (1985) display compositional characteristics identical to those of Mangaehuehu package lavas, and the glacially sculpted peak that exposes dikes (Hackett, 1985), is interpreted to represent the eroded vent-proximal region. Mangaehuehu package lavas cover an area of $\sim 100 \mathrm{~km}^{2}$, with distal flows exposed up to $18 \mathrm{~km}$ from Girdlestone Peak on the western flank of Ruapehu (Fig. 9).

At the time of emplacement, Mangaehuehu package lavas were bounded by glaciers between elevations of 2600 and $1500 \mathrm{~m}$ a.s.l. and they have been partly eroded and buried by subsequent glacial activity such that much of the surface of the southern flank is composed of 
glacial till and outwash. Exposures of stacked flows (Fig. 13a) and the distinct $\mathrm{MgO}$ and $\mathrm{K}_{2} \mathrm{O}$ contents of each sample within the total $\sim 57-62 \mathrm{wt} . \% \mathrm{SiO}_{2}$ continuum indicate that the samples represent a package of flows that were erupted from a common magma source that was tapped throughout a $\sim 7 \mathrm{kyr}$ eruptive period. The remote southern flank of the Ruapehu volcanic edifice had previously been sparsely sampled and was mapped predominantly as Wahianoa Formation (Hackett and Houghton, 1989; Price et al., 2012), meaning that this substantial cone-building episode had not previously been recognised. As their age range indicates, Mangaehuehu and Ngahuinga package lavas were emplaced contemporaneously, and no clear stratigraphic ordering between them can be ascertained due to their disparate spatial distributions. However, Mangaehuehu package lavas are inferred to underlie some Mangaturuturu and Ngahuinga lavas on the western flank of the volcano (Fig. 12).

\subsubsection{Mangaturuturu package (46-36 ka)}

This eruptive package comprises ice-bounded dacite lava flows erupted between $~ 46$ and 36 ka. These form a planèze on the western flank between the Mangaturuturu and Manganuioteao river valleys (Fig. 12). The flows overlie Wahianoa Formation lavas and breccias in the deeply incised upper catchment of the Mangaturuturu River (Fig. 12) and cap Ngahuinga andesites along the northern part of the once ice-bounded planèze (Fig. 13b). In addition to their restricted spatial location (Fig. 9), Mangaturuturu package lavas are differentiated from other dacite flows erupted during this time by their lower $\mathrm{MgO}$ contents at equivalent $\mathrm{SiO}_{2}$ and $\mathrm{K}_{2} \mathrm{O}$ contents (Table 3).

\subsubsection{Te Kohatu package (44-36 ka)}


Te Kohatu package dacite lavas were emplaced adjacent to large valley glaciers on the northwest flank between $\sim 44$ and $36 \mathrm{ka}$ and form prominent ice-bounded and ice-dammed flows between 1500 and 2100 m a.s.l. (cf. Conway et al., 2015; Figs. 11, 13c). An eruption age of $46 \pm 5$ ka determined for dacite sample T5-11 by Gamble et al. (2003) was not used to define the age range of the Te Kohatu package because it conflicts with the stratigraphic order of several dated flows on the northwest flank as constrained by new data presented here. Te Kohatu dacites are observed to overlie Te Herenga and Wahianoa formation lavas, and Mangaehuehu and Ngahuinga eruptive packages. A large ice-dammed flow within this package was emplaced within the broad, glaciated Whakapapaiti Stream valley at $42.6 \pm 1.8$ ka. Another Te Kohatu package ice-bounded flow emplaced at 39.1 \pm 1.4 ka overlies Ngahuinga package andesites exposed on the true left of the Whakapapaiti Valley (Fig. 11). The dacites also comprise two $>100$ m-thick ice-dammed flows emplaced at $39.2 \pm 2.0 \mathrm{ka}$ and $37.6 \pm 1.4 \mathrm{ka}$ at $\sim 1500 \mathrm{~m}$ a.s.1. on the western flank; the absolute WMPA values are consistent with the flows' stratigraphic positions. Based on their spatial distribution and icecontact margins, Te Kohatu package lavas were erupted from a central summit vent. Compared to other Ruapehu dacites, Te Kohatu package flows have higher MgO contents.

\subsubsection{Mananui package (42-38 ka)}

This package comprises a single dacite flow that was emplaced and dammed against a glacier on the lower northern flank at $40.3 \pm 2.2 \mathrm{ka}$ (Figs. 5, 9). The flow is isolated stratigraphically and spatially from other dacite flows higher on Ruapehu but is compositionally similar to dacite flows exposed at the Lower Tama Lake crater (Fig. 1; Hackett, 1985), which are here grouped within this eruptive package (Fig. 9). The Mananui dacite flow is characterised by $\mathrm{MgO}$ contents (2.8 wt. \%) midway between those of the Mangaturuturu (2.2 wt. \%) and Te 
Kohatu (3.3 wt. \%) package flows at equivalent $\mathrm{SiO}_{2}\left(\sim 64\right.$ wt. \%) and $\mathrm{K}_{2} \mathrm{O}(\sim 2.8$ wt. \%) contents. These geochemical characteristics are shared by a dacite clast sampled by Hackett (1985) from the 10.5 ka Murimotu Formation debris avalanche deposit on the ring plain north of the volcano, the source area of which coincides with a central vent location inferred for the Mananui dacite lava.

\subsubsection{Manganuioteao package (36-22 ka)}

Manganuioteao package andesite lavas were emplaced as ice-bounded flows on the western flank of Ruapehu at $30.9 \pm 2.2 \mathrm{ka}$ and on the northern ridge that bounds the glaciated Mangaturuturu River valley at $30.7 \pm 5.2 \mathrm{ka}$ (Figs. 10, 12). These flows cap older Te Kohatu and Mangaturuturu package dacites, although a younger Manganuioteao andesite dated at $27.2 \pm 4.8 \mathrm{ka}$ forms an ice-bounded flow inset within the Mangaturuturu valley relative to the older but topographically higher $\sim 41$ ka ice-bounded dacites and $\sim 31$ ka andesites (Fig. 12). The youngest dated lava within the Manganuioteao package is an ice-bounded flow emplaced at $25.7 \pm 2.6 \mathrm{ka}$, which is exposed at $1600 \mathrm{~m}$ a.s.l. on the southwestern flank. The Manganuioteao andesites are significant because they bridge the period between previously interpreted pulses of effusion at $\sim 45$ and $\sim 22 \mathrm{ka}$ (Gamble et al., 2003), thus demonstrating the continuity of effusive activity at this time. Moreover, the compositions of the flows (60-63 wt. \%) occupy a transitional geochemical field between older dacites and younger andesites.

\subsubsection{Whakapapaiti package ( 26 ka)}

Whakapapaiti package dacites were emplaced as ice-bounded flows that are exposed at the eastern base of the now-dissected Paretetaitonga Peak and on the upper western and 
southwestern flanks of Ruapehu (Figs. 2, 10). Only one lava has been dated, at $25.7 \pm 3.8 \mathrm{ka}$. The lavas are distinguished by their low $\mathrm{K}_{2} \mathrm{O}$ contents relative to dacite flows erupted from 46-35ka (Table 3).

\subsubsection{Horonuku package (29-15 ka)}

Horonuku package andesite lavas form major ice-bounded flows on eastern Ruapehu between elevations of 1600 and $1300 \mathrm{~m}$ a.s.l. (Fig. 10). Thicknesses of the flows and their heights above valley floors indicate that these flows were emplaced against $\sim 100 \mathrm{~m}$-thick glaciers. Two flows within this package were dated by Gamble et al. (2003) at $23 \pm 4 \mathrm{ka}$ and $22 \pm 7 \mathrm{ka}$ (Table 1), and no further dating of this package was undertaken in this study. The flows are overlain by till, and at higher elevations on the edifice by younger lava flows and pyroclastic deposits related to growth of the modern summit cones.

\subsubsection{Te Piripiri package ( 21 ka)}

Te Pirirpiri package lavas form the lower northeast flank of the Ruapehu edifice and have been blanketed by thick tephra deposits on the predominantly downwind side of the edifice. The flows exhibit evidence of lava-ice interaction (Conway et al., 2015) and were emplaced at $21 \pm 6 \mathrm{ka}$, as constrained by dating from Gamble et al. (2003). Andesite lavas of this package range from 58-60 wt. \% $\mathrm{SiO}_{2}$ and have average $\mathrm{MgO}$ contents of $\sim 5$ wt. \% (Table $3)$. 
This eruptive package is exposed on the southwest flank of Ruapehu and is constrained by eruption ages of $23.0 \pm 1.6 \mathrm{ka}$ (Table 2) and $23 \pm 8 \mathrm{ka}$ (Gamble et al., 2003). Despite covering a wide spatial extent and with exposure from 2200-1200 m a.s.l., the flows exhibit a tight compositional range with $\sim 62.1$ wt. $\% \mathrm{SiO}_{2}, \sim 3.6$ wt. $\% \mathrm{MgO}$ and 2.0 wt. $\% \mathrm{~K}_{2} \mathrm{O}$. Flows display evidence for interaction with glaciers, particularly between elevations of 2100 and 1700 m a.s.l. (e.g. Fig. 6c in Conway et al., 2015), and are overlain by moraines at elevations $<1600 \mathrm{~m}$ a.s.l., which have been dated by ${ }^{3} \mathrm{He}$ surface exposure geochronology at $\sim 15-11 \mathrm{ka}$ (Eaves, 2015).

\subsubsection{Makotuku package (24-16 ka)}

Makotuku package lavas were emplaced as ice-bounded and sub-glacial flows at midelevations on the south to south-eastern flank of the volcano. An extensive break-out flow, which overlies the Waitonga package lavas on the southwest flank of Ruapehu at $\sim 1300 \mathrm{~m}$ a.s.l., is also assigned to this package (Figs. 10, 13d; Conway et al., 2015). This stratigraphic ordering is supported by an age of $20.9 \pm 2.8$ ka measured from an ice-bounded flow at 1720 $m$ a.s.l. Lavas of this unit were also emplaced on southeast Ruapehu as ice-bounded or possibly sub-glacial flows (Conway et al., 2015). An eruption age of $17.8 \pm 2.2 \mathrm{ka}$ was measured for one flow, which is overlain by till that is interpreted to have been deposited at 15-11 ka (Eaves, 2015). Despite the interaction with glacial ice, fine-scale columns ( 10 cm-wide) are remarkably well-preserved on the margin of the flow, suggesting that only minor glacial activity occurred in the valley after emplacement of the flow and/or that the glacier was already retreating. Additionally, Makotuku andesites unconformably overlie the eroded core of the Wahianoa planèze beneath Mitre Peak on southeastern Ruapehu (Fig. 7), and the flows may have run onto and spilled over the edges of the former glacier to be 
sporadically preserved high above the valley on its northern and southern sides. Makotuku package flows are characterised by relatively low $\mathrm{SiO}_{2}$ and $\mathrm{MgO}$ contents compared to those of Waitonga package lavas (Table 3).

\subsection{Whakapapa Formation ( $<15 \mathrm{ka})$}

The Whakapapa Formation comprises post-glacial lava flows erupted since $15 \mathrm{ka}$ at Ruapehu (Hackett, 1985). Some lava flows mapped in this formation by Hackett (1985) and Price et al. (2012) are now re-assigned to older formations, while conversely some flows previously placed in the Mangawhero Formation are now assigned to the Whakapapa Formation. New ${ }^{40} \mathrm{Ar} /{ }^{39} \mathrm{Ar}$ geochronology data presented here also provide the first absolute ages for these flows (Table 2). Whakapapa Formation lavas are categorised into eruptive packages that form the mid-upper flanks of the edifice (Fig. 14). Of the post-glacial flows, two samples yielded positive eruption ages within $2 \sigma$ uncertainty of $0 \mathrm{ka}$ (Table 2 ). While the dating method precludes more precise chronological control, these are nevertheless valuable data that indicate late Holocene $(<5 \mathrm{ka})$ eruption ages for these lavas, consistent with their stratigraphic positions and geomorphological characteristics. A further 8 samples yielded WMPA of $\leq 15$ ka (Table 2). Time brackets for the eruptive packages are defined by taking into account individual ${ }^{40} \mathrm{Ar} /{ }^{39} \mathrm{Ar}$ WMPA and $2 \sigma$ uncertainties for all relevant flows in the package, or are given an approximate central age for packages with one dated flow. For flows without ${ }^{40} \mathrm{Ar} /{ }^{39} \mathrm{Ar}$ data, ages are inferred from geomorphic relationships or from their stratigraphic positions relative to ${ }^{14} \mathrm{C}$-dated local andesitic and TVZ rhyolitic tephras, as previously summarised in Price et al. (2012).

\subsubsection{Paretetaitonga package $(\sim 15 \mathrm{ka})$}


A sequence of 1-2 m-thick lava flows, breccias and pyroclastic material caps the peak of Paretetaitonga (2751 m a.s.l.; Fig. 15c) and the upper northwest flank of the volcano (Fig.

11). Lavas flowed into the Whakapapaiti Stream valley down to $\sim 1300 \mathrm{~m}$ a.s.l. Interaction of lava with snow and ice at upper levels (>2200 $\mathrm{m}$ a.s.1.) is evident in the form of deflected and impounded flow morphologies and the presence of fine-scale column-forming joints and pseudopillow fractures on flow margins (Conway et al., 2015). However, evidence for wholesale damming of these flows is absent, suggesting that ice was less extensive than during eruption of Mangawhero Formation lavas. Similarly the summit geometry of a partial cone formed of successive lavas suggests that a relatively ice-free vent area had been established. The timing of flow emplacement is constrained by an age of $14.8 \pm 3.0 \mathrm{ka}$, measured for a mid-sequence lava flow within the package. The age is further constrained because the flows were emplaced above the Whakapapaiti dacite $(25.7 \pm 3.8 \mathrm{ka})$ and by the switch to northern flank construction following sector collapse and emplacement of the Murimotu Formation debris avalanche deposit at 10.5 ka (see Iwikau package below). Individual flows were emplaced relatively rapidly, as they are stacked in a similar manner within the Whakapapaiti valley and share similar compositions (58.5 wt. \% $\mathrm{SiO}_{2} ; 4.5$ wt. \% $\mathrm{MgO} ; 1.6$ wt. $\left.\% \mathrm{~K}_{2} \mathrm{O}\right)$.

\subsubsection{Turoa package (17-10 ka)}

Andesite lavas of the Turoa package were emplaced above and adjacent to older ice-marginal flows over much of the southwest flank of the Ruapehu edifice at 1500-2800 m a.s.l. between the Mangaturuturu and Mangaehuehu valleys. The onset of effusion is constrained by an age of $15.1 \pm 2.4$ ka for a lava flow that was bounded to the south by a glacier that had a greater volume than the current Mangaehuehu Glacier. The youngest lavas are a group of at least 
three andesite flows erupted in quick succession that exhibit complex stratigraphic relationships with older ice-marginal flows on the flank west of Tahurangi. The middle flow of these three yielded an eruption age of $11.9 \pm 2.2 \mathrm{ka}$ (Table 2). An age of $>5 \mathrm{ka}$ is the only previous constraint on the timing of eruption of Turoa package lavas, which was provided by tephrostratigraphic relationships (Price et al., 2012).

Turoa package lava flows exhibit fracture textures indicative of interaction between lava and ice/snow at $\sim 1600 \mathrm{~m}$ a.s.l., although evidence of wholesale impoundment by ice is absent. The remnant southwest Turoa cone exhibits a relatively intact sequence of lavas to the westsouthwest, indicating that a relatively ice-free vent area and flank was established. However, the northern and eastern portions of the cone are absent (Fig. 15c) and are inferred to have collapsed to form the Mangaio Formation debris avalanche deposit, which was emplaced down the eastern flank at $4.6 \mathrm{ka}$ (Donoghue and Neall, 2001).

\subsubsection{Rangataua package $(\sim 15-10 \mathrm{ka})$}

Rangataua package consists of a $\sim 15 \mathrm{~km}$-long series of overlapping flow lobes and pyroclastic deposits on Ruapehu's southern flank (Hackett, 1985; Price et al., 2012). The source of the flow is uncertain: the topographically highest outcrop is at $1980 \mathrm{~m}$, where welded spatter and pyroclastic material was interpreted by Hackett (1985) to represent a collapsed vent. Alternatively, the vent may have been higher on the volcano and the lava flowed initially down the Mangaehuehu Glacier before it was diverted off the glacier through a low saddle to be emplaced on the relatively ice-free southern flank. Whichever hypothesis is correct, the Rangataua eruptive package was excluded from the Mangaehuehu valley to the west, likely due to the presence of valley-filling ice at the time of eruption. At lower elevations ( 1600-1400 m a.s.1.) the flow laps onto 15-11 ka moraines (Eaves, 2015). 
Rangataua package andesites are uniformly glassy, and no samples suitable for ${ }^{40} \mathrm{Ar} /{ }^{39} \mathrm{Ar}$ geochronology could be obtained. The $\sim 15-10 \mathrm{ka}$ age is therefore inferred from contact relationships with the moraines and exclusion of the lavas from the Mangaehuehu Valley, as well as tephrostratigraphic relationships, which indicate that the flows were emplaced at $12-$ 10 ka (Donoghue et al., 1995; Price et al., 2012).

\subsubsection{Tureiti package (15-9 ka)}

This package consists of glassy, flow-banded, slope-mantling lavas and pyroclastic material on the upper northeast flank of Ruapehu. Two lavas, which are dated at $12.5 \pm 2.6 \mathrm{ka}$ and $11.9 \pm 2.8 \mathrm{ka}$, overlie Te Piripiri package andesite lavas of the Mangawhero Formation and exhibit evidence (ice-contact fracture networks and flow morphologies) for interaction with 20 m-thick accumulations of ice/snow at 1400-1800 m a.s.l. The remnant Tureiti cone is well-formed and appears to have established a relatively ice-free vent area, however, its uppermost portion is not preserved. Distinct vent foci and magma systems are inferred for Tureiti and Paretetaitonga cones based on the compositional characteristics of their respective lava flows (Fig. 14; Table 3). In contrast, Tureiti package lavas are compositionally similar to those of the Rangataua package (Table 3), but their disparate locations also indicate distinct vent sources (Fig. 14).

\subsubsection{Iwikau package $(<10 \mathrm{ka})$}

This package comprises andesite lava flows erupted from a cone that is partly concealed beneath the present-day Summit Plateau ice field (Fig. 14). The north-western and eastern rims of the cone sit at a lower elevation $(<2700 \mathrm{~m})$ than the preserved remnants of Paretetaitonga $(2751 \mathrm{~m})$ and Tureiti $(2732 \mathrm{~m})$ packages, indicating that the summit height had 
been reduced prior to eruption of Iwikau package lavas. Changes to the summit morphology coincide with: (1) cessation of construction of the west-northwest Paretetaitonga packageforming cone ( 15 ka) and northeast Tureiti package-forming cone ( 12 ka), and (2) emplacement of the $\sim 10.5$ ka Murimotu Formation debris avalanche deposits on northern Ruapehu from a sector collapse event (Fig. 14; Palmer and Neall, 1989; Eaves et al., 2015). Iwikau eruptive package lavas were emplaced atop the Murimotu Formation on the northwestern flank of Ruapehu and are therefore inferred to be younger than $10.5 \mathrm{ka}$. Three distinct flow groups within the Iwikau eruptive package are defined on the basis of spatial distribution and geochemistry and are temporally constrained by new ${ }^{40} \mathrm{Ar} /{ }^{39} \mathrm{Ar}$ age data:

1. The Taranaki Falls lava flow $(8.8 \pm 2.8 \mathrm{ka})$ is rootless from the summit vent, likely due to emplacement over, or erosion by, a now-retreated glacier. Below $1700 \mathrm{~m}$ a.s.l. the flow is confined to the floor of the Wairere Stream valley and displays levees perched on the adjacent valley sides up to $80 \mathrm{~m}$ above the valley floor at the narrowest point in the valley (Fig. 5). This suggests that the lava was emplaced as a single flow that filled the valley before being drained. The flow terminates at $1120 \mathrm{~m}$ a.s.l. with a $40 \mathrm{~m}$-high bluff, which likely formed as the flow stalled on nearly flat ground rather than due to glacial impoundment. The Taranaki Falls flow was labelled as undifferentiated within the Whakapapa Formation by Price et al. (2012).

2. The voluminous Iwikau flows form the northern flank of the edifice from west of Pinnacle Ridge to the easternmost part of the upper Whakapapaiti Stream catchment (Fig. 5). These lavas unconformably overlie Tureiti package flows and form the prominent Te Heuheu and Tukino peaks on northern Ruapehu (Figs. 2, 14). Evidence for lava-ice interaction above $1800 \mathrm{~m}$ a.s.l. is present in the form of overthickened flow margins with fine-scale fracture networks indicative of chilling against ice (Conway et al., 2015). The timing of flow emplacement is constrained by our ${ }^{40} \mathrm{Ar} /{ }^{39} \mathrm{Ar}$ eruption age of $6.0 \pm 2.4 \mathrm{ka}$ (Table 2), on a 
sample collected from a mid-sequence flow within the group. This provides an absolute age constraint for this group of flows that fits within the $\sim 5-10$ ka range proposed by Nairn et al. (1998), but is older than the range of 2.5-3.3 ka presented by Price et al. (2012).

3. The Mangatoetoenui group of flows lies unconformably above Wahianoa Formation and Horonuku and/or Te Piripiri package flows of the Mangawhero Formation on the eastern flank of Ruapehu (Fig. 7). Interaction of flows with ice and till occurred on the summit (Fig. 15b) and upper flanks. Timing of the eruption of these flows is constrained by an age of $9.2 \pm 8.0 \mathrm{ka}$ for a flow at the Tukino ski field, which was ice-bounded and shows evidence for impoundment against a 60 m-thick glacier, consistent with an early Holocene eruption age. An age of $0.8 \pm 5.6 \mathrm{ka}$ was measured for a flow on the eastern flank at $1300 \mathrm{~m}$ a.s.l. that appears to have not been affected by lower flank ice (consistent with a late Holocene eruption age) and laps onto the lateral margin of an ice-bounded Tukino package andesite flow. Despite the relative imprecision of the new age data they represent the first constraints on the timing of eruption of these flows, which were not mapped within the Whakapapa Formation in Price et al. (2012). Mangatoetoenui lavas were previously recognised as having encountered ice by Spörli and Rowland (2006), and were assigned to the Mangawhero Formation on the assumption that ice of sufficient volume to bound the flow can only have been present at or before $20 \mathrm{ka}$. The new age data presented here instead indicate that ice thicknesses sufficient to impound 20-80 m-thick lava flows were present on the upper eastern flank at 1500-2200 m a.s.l. during the early Holocene. Glacial striae observed on the top of Mangatoetoenui lavas further indicate they were overrun, but not substantially eroded, by Holocene glaciers after their emplacement.

\subsubsection{Saddle Cone package ( $<10 \mathrm{ka})$}


The Saddle Cone package comprises the Holocene northern flank-vent-sourced Saddle Cone lavas and an isolated glassy lava flow on the northern flank at $\sim 1850 \mathrm{~m}$ a.s.l. (Figs. 5, 14). Previously inferred to have been erupted from a flank vent at $1990 \mathrm{~m}$ a.s.l. (Hackett, 1985), the upper isolated flow may instead have originated from a summit vent eruption that delivered the lava down an ice- or snow-covered surface to its preserved location. Saddle Cone andesites $\left(\sim 58.5\right.$ wt. $\left.\% \mathrm{SiO}_{2}\right)$ were erupted from the Saddle Cone vent at $1500 \mathrm{~m}$ a.s.l. The freshness of Saddle Cone package lavas is consistent with a $\sim 10$ ka eruption age, based on tephra cover sequences proposed by Nairn et al. (1998).

\subsubsection{Pinnacle Ridge fall deposit ( 10 ka)}

The Pinnacle Ridge fall deposit is an isolated unit of the post-glacial Whakapapa Formation (Figs. 5, 14; Hackett and Houghton, 1985, 1989). It is a welded pyroclastic fall deposit that has a distinctly higher $\mathrm{SiO}_{2}$ content ( 61 wt. \%) when compared to Iwikau eruptive package lavas (Hackett, 1985). It was erupted from a source close to its outcrop location on lower Pinnacle Ridge (Hackett and Houghton, 1985).

\subsubsection{Crater Lake package ( $<5 \mathrm{ka})$}

This eruptive package consists of the unconsolidated mound of tephra and lava that forms Pyramid Peak, which was erupted from a vent beneath the active Crater Lake (Figs. 2, 14) and a glassy andesite lava flow located within the Whangaehu valley (Fig. 12). This lava flow can be traced from its termination at $\sim 1300 \mathrm{~m}$ a.s.l. to a vent source at Crater Lake, and yielded a WMPA within error of present day $(0.2 \pm 2.2 \mathrm{ka})$. In contrast to all other postglacial flows, this lava has a relatively high $\mathrm{SiO}_{2}$ content of $\sim 61.5$ wt. $\%$, but lies within the 
wide compositional spectrum for historical products erupted through the Crater Lake ( 58-64 wt. \% $\mathrm{SiO}_{2}$ : Gamble et al., 1999; Nakagawa et al., 2002; Kilgour et al., 2013). Tephras of the $<2$ ka Tufa Trig Formation preserved on the southeast Ruapehu ring plain (Donoghue et al., 1995) are the pyroclastic counterparts of the effusive volcanic products of the Crater Lake package on the edifice.

\section{Discussion}

\subsection{Review of ${ }^{40} A r{ }^{\beta 9}$ Ar geochronology data}

Sequential sampling of stacked lava flows at composite volcanoes permits testing of the stratigraphic integrity of radioisotopic eruption age data and robust investigation of timecomposition relationships. Excepting flows of the Wahianoa Formation, thick sequences of lavas are rarely exposed at Ruapehu due to the relationship between volcano growth and fluctuations in ice volume. This interaction has resulted in complex stratigraphic contacts and lava flows with disparate, non-overlapping distributions (Conway et al., 2015). New and existing ${ }^{40} \mathrm{Ar} /{ }^{39} \mathrm{Ar}$ age data now form a high-fidelity 200 kyr-long chronostratigraphic framework (Fig. 16), which constrains effusive episodes in detail and allows interpretation of time-composition-volume relationships at Ruapehu. The eruption history is compared to the global paleoclimate record from Lisiecki and Raymo (2005) for the purpose of comparing the timing of volcanism to general periods of cooler and warmer climate as represented by the marine isotope stages (MIS; Fig. 16).

Previous workers have postulated that Ruapehu has an eruptive history that began $>100 \mathrm{kyr}$ prior to the age of its oldest 200 ka lavas (Tanaka et al., 1997; Gamble et al., 2003), although no eruptive products of such age have been described from the edifice. Age constraints from marine terraces, cover bed stratigraphy and ${ }^{40} \mathrm{Ar} /{ }^{39} \mathrm{Ar}$ eruption ages for lava clasts (geochemically correlated to Ruapehu) within distal debris flow deposits indicate that 
edifice growth had commenced at $\sim 340 \mathrm{ka}$ (Gamble et al., 2003; Tost and Cronin, 2015). No ages older than 200 ka were measured for exposed edifice lavas in this study.

At the opposite extreme, a key objective of this study was to test the limitations of the ${ }^{40} \mathrm{Ar} /{ }^{39} \mathrm{Ar}$ geochronometer for young flows of intermediate composition. WMPA eruption ages of $<5$ ka presented here (Table 2) are consistent with late Holocene ages interpreted from field evidence for the relevant flows. Three experiments on Holocene lavas produced $2 \sigma$ uncertainties of 2.2-2.8 ka, which are comparable to those for older Mangawhero Formation lava flows and permitted the discrimination of lava flows into early (10-5 ka) or late Holocene $(<5 \mathrm{ka})$ timeframes. This level of precision has rarely been achieved by ${ }^{40} \mathrm{Ar} /{ }^{39} \mathrm{Ar}$ dating in other studies of such young andesite lavas (e.g. Jicha, 2009). Our results support the application of ${ }^{40} \mathrm{Ar} /{ }^{39} \mathrm{Ar}$ dating to Holocene andesite lavas with optimal $2 \sigma$ uncertainties of $\sim 2$ kyr. This represents an important validation of the use of the ${ }^{40} \mathrm{Ar} /{ }^{39} \mathrm{Ar}$ dating method for high-altitude volcanoes where datable carbon is not preserved in association with lava flows. Holocene lava flows of the Rangataua and Saddle Cone eruptive packages were, however, unable to be dated because the holocrystalline interior zones required for precise dating were not exposed. . A combination of surface exposure and radiocarbon dating methods with ${ }^{40} \mathrm{Ar} /{ }^{39} \mathrm{Ar}$ geochronology is therefore necessary for reconstructing the Holocene eruptive histories of andesite-dacite composite volcanoes.

\subsection{Volcanic evidence for glacial history}

Recognising and incorporating volcano-ice interactions into geological mapping of glaciated composite volcanoes is important for understanding their eruptive histories and morphologies, and can also provide valuable paleoclimate information (Stevenson et al., 2006). The crystalline or well-lithified nature of glaciovolcanic deposits (i.e. lava flows and 
volcanic breccias that have interacted with ice: Edwards et al., 2015) makes them resistant to erosion and, therefore, useful for extracting geochronological information that is pertinent to former ice extents (Russell et al., 2014). This gives them an advantage over glacial deposits and landforms such as till and moraines, which are susceptible to erosion between and during subsequent glaciations. Ruapehu has coeval eruptive and glacial histories and the past presence of ice on the edifice has strongly influenced emplacement and preservation of effusive products (Conway et al., 2015). Defining the temporal distributions of effusive glaciovolcanic products using ${ }^{40} \mathrm{Ar} /{ }^{39} \mathrm{Ar}$ geochronology provides constraints on the presence and surface elevation of valley-filling ice at Ruapehu. Glacial impoundment and the associated overthickening and slow cooling of the interior zones of thick flows of the Mangawhero Formation, in particular, have produced favourable groundmass textures for ${ }^{40} \mathrm{Ar} /{ }^{39} \mathrm{Ar}$ dating. These zones have been exposed via erosion of the steep and finely fractured quenched lava flow margins. Fortuitously, Mangawhero Formation lava flows also contain relatively high $\mathrm{K}_{2} \mathrm{O}$ contents that further aid ${ }^{40} \mathrm{Ar} /{ }^{39} \mathrm{Ar}$ measurement. The 2 sd uncertainties of 2-3 kyr for the geochronology data presented here provide high-precision constraints that complement ice extent reconstructions by Eaves (2015) for the period 50-15 ka.

\subsubsection{Sub-glacial volcanism}

Edifice-forming units of volcaniclastic breccia that underlie sequences of lava flows emplaced from $200 \mathrm{ka}$ (Te Herenga Formation) and 166 ka (Wahianoa Formation) were originally interpreted as hydrothermally altered vent-association breccias (Hackett and Houghton, 1989; Smith et al., 1999). Their volcanic origins are re-interpreted here as hyaloclastite breccia formed via magma-water/ice interaction. Basaltic and rhyolitic hyaloclastites have been described from Iceland and Antarctica (e.g. McGarvie, 2009; 
Skilling, 2009; Smellie et al., 2011), although intermediate composition subglacial hyaloclastite breccias have only been observed or documented very rarely (e.g. Stevenson et al., 2009). Emplacement of the hyaloclastite mounds at Ruapehu was also associated with ice-marginal effusion of basaltic-andesite lava flows. Once eruptive vents breached the surface of the confining glaciers and meltwater, lavas flowed downslope between glaciers and were sequentially emplaced in positions marginal to glaciers at lower elevations. The northern ridges (Te Herenga Formation) and southeast planèze (Wahianoa Formation) are interpreted to have formed in this way. These older edifices resemble tindar ridges or complex tuyas, but without the wide coherent lava caps typical of basaltic tuyas (Russell et al., 2014). Exposed thicknesses of basal hyaloclastite breccias of the Te Herenga and Wahianoa formations are $\geq 100 \mathrm{~m}$, indicating that glaciers of at least that thickness of ice were present.

The most precise eruption ages measured for Te Herenga Formation lavas are between $\sim 190$ and 170 ka (Fig. 16). Emplacement of Te Herenga Formation hyaloclastite breccias are therefore inferred to have occurred during this time, which coincides with the glacial MIS 6 (Fig. 16; Lisiecki and Raymo, 2005). Hyaloclastite breccias beneath the Wahianoa Formation on the southeastern flank of Ruapehu are also assigned a MIS 6 emplacement age based on their position beneath lavas with eruption ages of $<160 \mathrm{ka}$. This reconstruction implies that the large ice caps and glaciers were sustained on Ruapehu at elevations of $>1500 \mathrm{~m}$ a.s.l. throughout MIS 6. An earlier edifice, reflecting volcanism at Ruapehu from 340 ka (Gamble et al., 2003; Tost and Cronin, 2015), provided sufficient elevation to host the ice mass. The elevation information taken from the distribution of the Te Herenga and Wahianoa formation breccias should be considered in the context of subsidence associated with down-faulting and extension, although suitable data are not available to quantify this issue (Villamor and Berryman, 2006a). 


\subsubsection{Preservation and exposure of MIS 5 volcanic products at Ruapehu}

It has been proposed that the deflection of lava flows by valley glaciers toward emergent ridges occurs during glacial periods in contrast to emplacement of lavas within valleys during interglacial periods (Lescinsky and Sisson, 1998). While the relationship between an interglacial climate and consequent valley-floor lava emplacement is evident for Holocene flows at Ruapehu volcano (Conway et al., 2015), it is harder to ascertain the same link for older interglacial lavas that may have been subsequently eroded and/or buried. The hypothesis of valley-floor lava emplacement was tested for MIS 5, a relatively warm period and a previously inferred period of eruptive inactivity (Fig. 16; Gamble et al., 2003), by measuring eruption ages for lava flows with characteristics of interglacial flows (i.e. intravalley locations, low slope angles, not over-thickened, long-run-out distances, covered by till). Eruption ages of $95.9 \pm 3.5$ and $88.1 \pm 3.2$ ka were measured for two such lava flows, which fall within MIS 5 (Lisiecki and Raymo, 2005). These lava flows have comparable compositions to older planèze-forming lava flows of the Wahianoa Formation, and are therefore inferred to represent products from a continued magma system rather than being sourced from a new system that commenced at $\sim 100 \mathrm{ka}$. The previously proposed eruptive hiatus at $\sim 115-80 \mathrm{ka}$ (Gamble et al., 2003) is interpreted to reflect a sampling gap for poorly preserved lavas erupted during middle-late MIS 5 (Fig. 16). This is likely to be a common feature at glaciated composite volcanoes globally (e.g. Volcán Parinacota: Hora et al., 2007).

\subsubsection{Glacier reconstructions using ice-marginal lava flows}


The primary focus of previous studies of the lava-ice interaction has been to establish the physical processes of lava flow emplacement (e.g. Lescinsky and Sisson, 1998; Lescinsky and Fink, 2000; Lodge and Lescinsky, 2009). Providing constraints on the timing of lava-ice interaction has received less attention and, where available, eruption ages have generally been provided for ice-bounded flows that are isolated from a coherent volcanic stratigraphy (e.g. Lodge and Lescinsky, 2009; Mee et al., 2009). As a result, neither sequences of dated flows nor geochronological datasets that cover wide spatial distributions across volcanic edifices have been presented. This study enables past glacier fluctuations on the flanks of a volcano to be measured using the positions and ages of lavas that were bounded by ice.

As a background, in a compilation of paleoclimate records from speleothems, Williams et al. (2015) identified that during the last glaciation (MIS 4-2), peak glaciation in New Zealand occurred at 66-61 ka (Schaefer et al., 2015), an advance of mountain glaciers occurred at $\sim 42-38 \mathrm{ka}$, and the New Zealand equivalent of the global LGM (i.e. 26-19 ka: Clark et al., 2009) occurred at $32-28 \mathrm{ka}$. Exposure age dating of moraines in the South Island of New Zealand led to the identification of moraine-building events under full glacial conditions at $\sim 42 \mathrm{ka}, \sim 28-25 \mathrm{ka}, 21 \mathrm{ka}$ and $18 \mathrm{ka}$ (Putnam et al., 2013a, b; Kelley et al., 2014). At Tongariro volcano, adjacent to Ruapehu, two glacial advances are recorded by moraine formation at $>57 \mathrm{ka}$ and $\sim 30-18 \mathrm{ka}$ (Eaves et al., 2016b).

Glacier thicknesses at Ruapehu through time have been constrained here by a compilation of the elevations, extents, distances above valley floors, and ages for lava flows that were emplaced against valley-filling glaciers (Fig. 17). The vertical offset of ice-marginal flows above glaciated valley floors is used to estimate former glacier thicknesses (values rounded to nearest $10 \mathrm{~m})$. The data indicate that glaciers were 100-160 m-thick at elevations of $\sim 1500 \mathrm{~m}$ a.s.l. between $\sim 48$ and $35 \mathrm{ka}$. Moraines and the occurrence of ice-marginal flows at lower elevations indicate that glaciers descended to $\sim 1200 \mathrm{~m}$ a.s.l., consistent with full glacial 
conditions (McArthur and Shepherd, 1990; Eaves et al., 2016a). Synchronous cooling between Antarctica and New Zealand at $~ 42$ ka has been proposed from moraine evidence in the South Island (Kelley et al., 2014). The age data for ice-marginal dacite lava flows on northwest Ruapehu serve to indicate similarly cool conditions were still present at $\sim 38 \mathrm{ka}$.

A sequence of ice-bounded flows that forms the northern side of the deeply incised Mangaturuturu River valley (Fig. 2) allows a detailed interpretation of glacier thickness fluctuation during MIS 3-2. With increasing height above the glaciated valley floor, lava flows yielded ages of $27.2 \pm 4.8 \mathrm{ka}, 43.4 \pm 2.4 \mathrm{ka}, 40.7 \pm 4.6 \mathrm{ka}$, and $30.7 \pm 5.2 \mathrm{ka}$ (Fig. 12). A separate but proximal lava flow within the Manganuioteao package dated at $30.9 \pm 2.2 \mathrm{ka}$ is also elevated above its adjacent glacial valley by $\sim 180 \mathrm{~m}$. The distribution of dated lava flows indicates that the glacier thickness within the Mangaturuturu valley was greater at $\sim 31$ ka than at $\sim 44-35 \mathrm{ka}$. The glacier is inferred to have retreated rapidly after $\sim 31 \mathrm{ka}$ to account for the ice-marginal emplacement of a flow closer to the valley floor at $\sim 27 \mathrm{ka}$.

Emplacement of eruptive products and/or edifice collapse may have changed the summit and flank morphology of Ruapehu and, in doing so, altered ice pathways to restrict or enhance glacier flow into different catchments independently of climate changes. Notably though, the 31 ka timing of maximum glacier thicknesses on western Ruapehu is broadly consistent with full glacial conditions in the South Island at $28 \mathrm{ka}$ (Kelley et al., 2014) and prior to 26 ka (Rother et al., 2015) and the inference of New Zealand's global LGM equivalent at 32-28 ka (Williams et al., 2015). The distribution of ice-bounded flows erupted between $\sim 28$ and 18 ka on southwest Ruapehu indicates that glacier thicknesses during this period were $<100 \mathrm{~m}$ at elevations of 1500-1700 m a.s.l. The data imply that glacial conditions at Ruapehu during the global LGM at $\sim 20 \mathrm{ka}$ were not as fully developed as during former periods of cooling centred around $\sim 42$ and $\sim 31 \mathrm{ka}$. Constraining the timing and extent of glacier advances at composite volcanoes with overlapping Late Quaternary glacial and eruptive histories along 
the Aleutian, Andean, Cascade and Kamchatka continental volcanic arcs may be similarly possible by integrating field and geochronological datasets in such settings (e.g. Fierstein et al., 2011).

Lava flows with ages of $<20$ ka provide key clues to the rates of deglaciation at Ruapehu. The $17.8 \pm 2.2 \mathrm{ka}$ age of an ice-bounded andesite flow that was emplaced against a $>50 \mathrm{~m}$-thick ice-wall within the Wahianoa River valley indicates that glacial retreat was underway by this time. Although the flow interacted with ice, it is $~ 200 \mathrm{~m}$ lower than moraine crests bounding the valley, which was fully glaciated at $\sim 43 \mathrm{ka}$ as indicated by eruption ages for ice-bounded lavas on its western side (Fig. 7). Any post-LGM glacial advances within the valley did not significantly erode the fine cooling columns that characterise the $17.8 \mathrm{ka}$ flow. Changes in the distribution and morphology of lava flows erupted since $\sim 15$ ka reflect the post-LGM history of Ruapehu. On the upper flanks (>2200 m a.s.l.) of the edifice <15 ka lava flows display evidence (i.e. localised ice-contact fracture networks, metre-scale overthickening, superficial glacial striae) for minor interaction with glaciers similar in extent to those present in historic times (Heine, 1963). At <1700 m a.s.l., $<15 \mathrm{ka}$ lava flows were emplaced on the floors of the previously glaciated valleys. Eruption ages for these flows constrain wholesale glacier retreat at Ruapehu to between 18 and $15 \mathrm{ka}$. However, any glacial fluctuations in response to shortterm climate variability since $\sim 18$ ka on Ruapehu are complex (Eaves, 2015) and beyond the resolution of our ${ }^{40} \mathrm{Ar} /{ }^{39} \mathrm{Ar}$ dataset.

\subsection{Compositional evolution of Ruapehu lava flows}

The compositional ranges of eruptive products in continental arc volcanoes often display linear compositional spectra that extend from basalt to dacite and, occasionally, rhyolite (e.g. Hildreth et al., 2003; Hora et al., 2007; Hildreth and Fierstein, 2012). The time-sequenced 
geochemical variations of eruptive products are typically non-systematic, however, and do not necessarily reflect the long-term evolution of a common magma source by simple progressive fractionation and assimilation (e.g. Eichelberger et al., 2006). However, a common conception is that magma systems evolve toward producing more silicic eruptive products over time periods of $>100 \mathrm{kyr}$. This idea is founded on the association of nonevolved (mafic) eruptive products with stratigraphically old portions of volcanic edifices, then the eruption of more evolved lavas and, in some cases, the incidence of climactic explosive eruptions of silicic magma later in the history of composite volcanoes (e.g. Bacon and Lanphere, 2006; Hora et al., 2007; Singer et al., 2008; Escobar-Wolf et al., 2010; Price et al., 2012). High-resolution temporal frameworks are required in order for time-composition trends to provide valuable information on the timescales of magma heterogeneity and the overall evolution of magma systems (e.g. Dungan et al., 2001). While the magmatic evolution of Ruapehu has been explored in previous work (Graham and Hackett, 1987; Gamble et al., 1999; 2003; Price et al., 2005; 2012), the improved chronological control and sampling resolution achieved in this study permit further interrogation of the time-composition trends.

Whole-rock geochemical analyses of Ruapehu lavas show archetypical continental crust-like major and trace element characteristics of global orogenic andesites and dacites (Cole, 1978; Gill, 1981). On closer inspection, they comprise diverse crystal cargoes hosted within dacitic to rhyolitic melts and are interpreted to represent the products of a complex interplay of assimilation, crystal fractionation, crustal anatexis and magma mixing processes within the lithosphere (Hildreth and Moorbath, 1988; Gamble et al., 1999; Price et al., 2012). The extent of magma differentiation generated by the combination of these processes has been inferred to have generally increased with time as interpreted from increasing $\mathrm{SiO}_{2}$ contents and ${ }^{87} \mathrm{Sr} /{ }^{86} \mathrm{Sr}$ values in progressively younger eruptive products (Graham and Hackett, 1987; Price 
et al., 2012). However, until now a lack of age data for post-50 ka lava flows has precluded a detailed investigation of this trend.

Ruapehu lava flows display a gradual increase in $\mathrm{SiO}_{2}$ and $\mathrm{K}_{2} \mathrm{O}$ abundances from 200 to 80 ka (Fig. 18). Following a gap in effusive activity between 80 and $50 \mathrm{ka}$, compositional diversity was greatest during the period from $~ 48-35 \mathrm{ka}$ and, despite a lack of lavas with $\mathrm{SiO}_{2}$ contents between $\sim 62$ and 63 wt. \%, effusion of dacite was prevalent during this time. Based on their $\mathrm{MgO}$ contents, lavas erupted between 48 and $35 \mathrm{ka}$ define a broad bimodal diversity (Fig. 19). Mangaehuehu package andesites and Te Kohatu package dacites form a high-MgO trend when plotted against $\mathrm{SiO}_{2}$, whereas Ngahuinga package andesites and Mangaturuturu package dacites align with a lower- $\mathrm{MgO}$ compositional array, which is also representative of all other Ruapehu lavas (Fig. 19). The only other Ruapehu lavas that plot on the high-MgO trend are $26 \mathrm{ka}$ Whakapapaiti package dacite flows, although these have distinctly lower $\mathrm{K}_{2} \mathrm{O}$ concentrations (Table 3 ). The coeval eruption of compositionally distinct andesite and dacite packages, some of which have wide-ranging linear trends, implies the presence of a complex magma system for Ruapehu volcano at this stage of edifice growth. A gap in lava flow ages at $\sim 80-50$ ka precedes this phase (Fig. 16) and may represent a period during which magma bodies were stalled and differentiated by a range of processes, including mixing, crystal fractionation and crustal assimilation.

Lava flows erupted at $\sim 30$ ka have a relatively narrow range of compositions that are intermediate within the range defined by the $48-35$ ka lavas and fall within the $62-63$ wt. \% $\mathrm{SiO}_{2}$ compositional gap mentioned above (Fig. 19). Post-26 ka lava flows display a trend to progressively less silicic and less potassic compositions with time, following eruption of Whakapapaiti package dacites (Fig. 18). The one exception to this trend is the late Holocene Whangaehu lava flow within the Crater Lake eruptive package (61.5 wt. \% $\left.\mathrm{SiO}_{2}\right)$. The strength of this trend contrasts with prior studies that surmised that Ruapehu eruptive 
products have generally become more evolved and compositionally variable with time (Graham and Hackett, 1987; Gamble et al., 1999; Price et al., 2012). This inference was influenced by inaccurate age control and incomplete sampling, and has been refined with the improved chronostratigraphy provided in this contribution.

A model of random tapping of small batches of magma that have followed distinct lithospheric pathways of mixing and contamination has been inferred to explain the generation of magmas and their complex and non-systematic geochemical changes over timescales of tens of years to tens of kyr observed at Ruapehu (Gamble et al., 1999, 2003; Price et al., 2005, 2012) as well as globally (e.g. Dungan et al., 2001; Frey et al., 2004). In contrast, the enlarged dataset and careful sequencing of lavas presented here reveals a systematic and coherent long-term compositional evolution of effusive products. These trends will be explored further elsewhere.

\subsection{Integrating explosive and effusive records at Ruapehu}

Effusive and explosive records are only rarely integrated in the study of complex volcanoes or volcanic fields (e.g. Hildreth and Fierstein, 2012) due to the different distributions and preservation potentials of lava flows and pyroclastic deposits. Amalgamating the two is important for understanding the hazards and periodicity of eruptive behaviour at arc volcanoes. Pyroclastic deposits on Ruapehu volcano are well-characterised for the period from 27-10 ka (Donoghue et al., 1995; Cronin and Neall, 1997; Pardo et al., 2012), which coincides in time with frequent effusive activity (Fig. 16). Lava flows with varied compositions and spatial distributions were erupted at this time (Figs. 9, 10, 14), indicating that vents tapped multiple different magma reservoirs during this period. 
The composition, age and spatial distribution of Mangawhero Formation lavas and Whakapapa Formation lavas that formed post-glacial cones (northwest cone of $\sim 15 \mathrm{ka}$ Paretetaitonga package lavas; southwest cone of $\sim 17-10$ ka Turoa package lavas; and northeast cone of Tureiti package lavas at $~ 15-9 \mathrm{ka}$ ) are compared with tephras to test whether these cones were the sources for both effusive and explosive eruptions (Fig. 20). Te Piripiri package lavas $(21 \pm 6 \mathrm{ka})$ and Mangatoetoenui eruptive unit tephras ( 22 ka) on northeast Ruapehu display distinctly lower $\mathrm{SiO}_{2}$ and $\mathrm{K}_{2} \mathrm{O}$ contents than other eruptive products of this age, although they do not overlap in composition (Fig. 20). Tephras of the Shawcroft ( 13 ka), Oruamatua (13-12 ka), and Okupata-Pourahu (11.6 ka) eruptive units (terms from Donoghue et al., 1995) define a compositional range that overlaps with lava flows of the same age (Fig. 20).

Pardo et al. $(2012,2014)$ suggested that the vent focus changed from north to south on Ruapehu's summit plateau for the $\sim 11.6$ ka eruptive phase based on isopach maps for tephra deposits. New results presented here indicate that voluminous effusive activity was occurring from both northern and southern vents during this period giving rise to emplacement of Tureiti and Turoa package lavas, respectively. Effusive activity later continued from a northern vent that erupted the Taranaki Falls flow $(8.8 \pm 2.8 \mathrm{ka})$, Iwikau flows $(6.0 \pm 2.4 \mathrm{ka})$ and Mangatoetoenui flows $(0.8 \pm 5.6 \mathrm{ka})$. These lava flow extents and ages preclude a complete switch to a southern eruptive vent at $11.6 \mathrm{ka}$ as inferred by Pardo et al. (2012, 2014).

The systematic long-term variation of lava flow compositions outlined in section 5.3 contrasts with the wide compositional array of historic pyroclastic deposits, which encompasses the $\mathrm{SiO}_{2}$ content of most post-glacial Whakapapa Formation lavas (Gamble et al., 1999; Nakagawa et al., 2002; Kilgour et al., 2013; Fig. 20). This distinction likely reflects a difference in the sizes of the magma bodies involved in the respective eruptive styles: lavas 
were sourced from larger and more homogenized magma bodies whereas historical pyroclastic eruptions have tapped small, ephemeral and isolated magma bodies. Both effusive and explosive activity have occurred in parallel through to the late Holocene, however, with the exception of volumetrically minor lava dome-building eruptions, explosive eruptions have dominated the historical eruptive record (Houghton et al., 1987). Conversely, pyroclastic eruptions with volumes similar to historic events have not been well-preserved in the prehistoric geological record.

\subsection{Edifice-ring plain relationships}

Composite volcanoes are inherently unstable due to the deposition of complexly intercalated lavas and pyroclastic deposits at high elevations on steep slopes. Glaciated volcanoes are additionally prone to sector collapse due to the prevalence of glacial erosion and ice-marginal lava emplacement processes in addition to hydrothermal alteration, all of which act to destabilise volcanic material. The recognition of glacial debuttressing as a key factor in the generation of landslides in alpine settings (e.g. Cossart et al., 2008) also applies to glaciated volcanoes (e.g. Capra et al., 2013). The volume of Ruapehu's edifice is matched by its surrounding ring plain (Hackett and Houghton, 1989), reflecting a high flux of volcaniclastic material. Previous workers have suggested that erosion during glacial periods MIS 4 and 2 resulted in accelerated lahar deposition on northeast Ruapehu (Cronin and Neall, 1997). In contrast, Tost et al. (2014) inferred that large volume sector collapse events from Ruapehu occurred at the transition from glacial to interglacial periods during the period of $~ 340-200$ ka. Links between Ruapehu's edifice and ringplain are evaluated here through consideration of the processes that governed edifice instability throughout its growth history. 


\subsubsection{Links between syn-glacial volcanism and ring plain deposits}

The recognition of volcano-ice interaction processes at Ruapehu has implications for understanding the generation of debris avalanches and lahars. First, widespread evidence for lava-ice interaction in the Mangawhero Formation (50-15 ka) indicates that large flank glaciers were then extant on Ruapehu. Modelling indicates that glaciers of such volume were likely fed by a large summit ice mass (Eaves et al., 2016a). Lavas could only be emplaced on glaciated flanks of the edifice if eruptive vents were able to penetrate the summit ice field and feed material to emergent planèze flanks between valley glaciers (Lescinsky and Sisson, 1998). In doing so magma-ice interaction must have generated: (1) large quantities of meltwater as the ice was melted (Wilson and Head, 2007); and (2) volcaniclastic deposits that were subject to intense hydrothermal alteration as lava was fragmented and fluxed by meltwater and steam (e.g. Tuffen et al., 2001).

Mixtures of lava, ash and meltwater would have produced syn-eruptive lahars, and the presence of hydrothermally altered deposits especially in the summit vent area may have had a longer-lasting impact by forming an unstable substrate upon which subsequent summit lavas were emplaced. Such deposits are exposed between Tahurangi and Girdlestone Peak. Moreover, widespread ice-marginal emplacement of lavas at Ruapehu during MIS 3-2 produced steep, thick, and pervasively fractured lava flows that would be prone to collapse and produce debris avalanches (e.g. Hickson, 2000). The collapse of ice-marginal lava flows onto glaciers during glacial periods (when ice extent fluctuated) or into valleys during interglacial periods are likely to have generated debris avalanches at Ruapehu. Third, a proportion of lava flows was likely emplaced onto glaciers during eruption and eventually conveyed to the ring-plain as clastic material fragmented by quench-contraction and glacial abrasion. The revised chemostratigraphy of Ruapehu volcano will enable ring plain debris 
avalanche and laharic deposits to be matched with corresponding dated ice-marginal lavas on the edifice using geochemical correlation in future studies.

\subsubsection{Causes of Holocene sector collapse events at Ruapehu}

Recognition and dating of major stratigraphic unconformities can provide understanding of the factors that promote sector collapses at composite volcanoes (e.g. Ownby et al., 2007). Two major Holocene sector collapse events resulted in the emplacement of debris avalanche deposits on the northern and south-eastern flanks of Ruapehu. The Murimotu Formation is a hummocky debris flow deposit on northern Ruapehu that was emplaced at $~ 10.5 \mathrm{ka}$ (Palmer and Neall, 1989; Eaves et al., 2015). The Mangaio Formation comprises debris diamictons emplaced on the south-eastern flank of Ruapehu at $4.6 \mathrm{ka}$ (Donoghue et al., 2001). The $\sim 10.5 \mathrm{ka}$ age of the Murimotu Formation follows the emplacement of lava flows of the Paretetaitonga $(14.8 \pm 3.0 \mathrm{ka})$ and Tureiti $(12.5 \pm 2.6 \mathrm{ka} ; 11.9 \pm 2.8 \mathrm{ka})$ eruptive packages on the upper northwest and northeast flanks respectively. These lavas form now-truncated summit cone structures that surround the inferred source position of the collapse (Figs. 14, 21). The cones are inferred to have been ice-bounded at the summit due to evidence for ongoing lava-ice interaction for upper flank lava flows of this age (Fig. 15a) and the deposition of $\sim 15-11 \mathrm{ka}$ moraines at elevations of $\sim 1800 \mathrm{~m}$ a.s.l. (Eaves, 2015). The presence of a summit ice cap during cone construction is likely to have resulted in the production of clastic deposits during interaction with ice and/or water and extensive hydrothermal alteration of deposits (Fig. 15b). Due to the preceding 30 kyr of volcano-ice interaction during MIS 3-2, it is also expected that the summit region was composed of hydrothermally altered and fragmental deposits with steep topographic relief, which would have formed an inherently unstable base beneath the younger cones (Fig. 15a). 
Previous hypotheses for the generation of the northern sector collapse invoked destabilisation of the northwest flank due to emplacement of a dacite cryptodome (McClelland and Erwin, 2003) or intrusion of dikes (Hackett and Houghton, 1989; Palmer and Neall, 1989).

Emplacement of a dacite lava dome was proposed based on the measurement of $\sim 350^{\circ} \mathrm{C}$ emplacement temperatures for clasts within the deposit (McClelland and Erwin, 2003).

Geochemical analyses were not undertaken for the clasts from which geomagnetic data and emplacement temperatures were acquired, however, and only one study has reported a dacitic clast within the Murimotu Formation (Hackett, 1985). Substantial dacite effusion occurred between 46 and $36 \mathrm{ka}$ (Figs. 9, 18), with a later episode at $26 \mathrm{ka}$, that produced lava flows on the northern and western flanks. There is no precedent for dome-forming activity during these periods of dacite effusion at Ruapehu recorded on the exposed edifice. Contrary to Hackett and Houghton (1989), dacite flows have now been mapped on the upper northwest flank of the Ruapehu edifice (Figs. 9, 10) and are exposed within the sector collapse scar region at $2600 \mathrm{~m}$ a.s.l. (Fig. 15a). Furthermore, effusion of dacite at $\sim 10.5 \mathrm{ka}$ is contrary to the coherent trend towards basaltic-andesite compositions seen in eruptive products since $\sim 26$ ka (Fig. 18). The occurrence of dacite clasts within the deposit can be accounted for by incorporation of older Mangawhero Formation dacite flows from the source area, as proposed by Palmer and Neall (1989). The presence of distinct dacite compositions within the Mangawhero Formation allows the Murimotu Formation clast analysed by Hackett (1985) to be linked with the Mananui package flow (Fig. 19). This dacite flow on northern Ruapehu is inferred to have been erupted from a central or northern vent that coincides with the area of edifice collapse (Figs. 9, 21).

Deglaciation is here considered a primary factor for the $10.5 \mathrm{ka}$ sector collapse, although an earthquake or eruption may have provided the immediate trigger for failure. Post-LGM warming is inferred to have been a global trigger for sector collapses at glaciated volcanoes, 
due to the debuttressing of volcanic material emplaced against ice or undercut by glacial erosion, lithospheric unloading and associated faulting, increased fluid circulation, and initiation of a more humid climate (Capra, 2006). Wholesale deglaciation of the Ruapehu edifice is inferred to have occurred from 18-15 ka, as discussed above (Section 5.2), although a summit ice cap and upper flank glaciers are likely to have remained for several kyr after the initial onset of deglaciation at $18 \mathrm{ka}$. Rapid climate amelioration from $\sim 11 \mathrm{ka}$ is indicated by regional records (e.g. Newnham et al., 2003). The retreat of glaciers and summit ice would have debuttressed the Paretetaitonga and Tureiti cones and resulted in destabilisation of the steep, hydrothermally altered edifice underlying the cones.

The 10.5 ka collapse event occurred during a period of regional extension and elevated volcanic activity around the northern flank of Ruapehu (Nairn et al., 1998), and disruption via seismic or volcanic activity may have ultimately triggered the collapse. A similar process is invoked for emplacement of the 4.6 ka Mangaio Formation debris avalanche deposit on southeast Ruapehu caused by collapse of the northeastern portion of the southern cone that is composed of Turoa package lava flows. Destabilisation of the cone during Holocene glacial retreat is here proposed to have caused its collapse into the Whangaehu River valley following emplacement of the cone's uppermost lavas at $11.9 \pm 2.2 \mathrm{ka}$. The inferred link between deglaciation and sector collapse at Ruapehu volcano serves as a warning for future potential hazards during the current period of rapid warming and deterioration of ice masses on glaciated composite volcanoes in mid-latitudinal regions (e.g. Rivera et al., 2006).

\subsection{Eruptive volumes and rates}

The long-term eruptive rate for Ruapehu of $0.6 \mathrm{~km}^{3} \mathrm{kyr}^{-1}$ since $\sim 250 \mathrm{ka}$ (using a total edifice volume of $150 \mathrm{~km}^{3}$ ) was previously determined by Hackett and Houghton (1989) and 
Gamble et al. (2003). The rate is $1.2 \mathrm{~km}^{3} \mathrm{kyr}^{-1}$ when the equivalent volume of ring plain deposits is included. These rates are broadly comparable to those calculated for Mt. Katmai (0.79 $\mathrm{km}^{3} \mathrm{kyr}^{-1}$ : Hildreth et al., 2003b) and El Misti (0.63 $\mathrm{km}^{3} \mathrm{kyr}^{-1}$ : Thouret et al., 2001), but are substantially greater than those for most other well-dated composite volcanoes, which are $<0.35 \mathrm{~km}^{3} \mathrm{kyr}^{-1}$ (Table 4). Conservative volumes for eruptive products of Ruapehu were calculated here using the revised mapping results of this study (Table 4).

A large volume of the modern edifice is composed of till that within any one glacial catchment can represent a diverse assemblage of clasts of variable age and composition. It is therefore impossible to reconstruct the volumes of lava from individual formations and eruptive packages that comprise moraines and outwash fans on the Ruapehu edifice. However, estimated volumes of glacially eroded eruptive products from the Te Herenga, Wahianoa and Mangawhero formations are incorporated into the measurements made in this section. Half-volumes of right-angle circular cones were calculated to approximate preeroded volumes of $28 \mathrm{~km}^{3}$ and $74 \mathrm{~km}^{3}$ for the Te Herenga and Wahianoa formations, respectively (Table 4). These calculations oversimplify the geometry of the volcanic edifices formed during these periods of volcanism but are intended to compensate for the substantial amounts of material that have been eroded and transported to the ring plain.

An eruptive volume of $28 \mathrm{~km}^{3}$ for the Mangawhero Formation was calculated by applying average lava flow thicknesses based on field observations to the measured areal extent of synglacial lava flows. The estimate also incorporates the inferred volume of lava flows emplaced onto glaciers and subsequently eroded. The volume of lava transported to the ring plain by glaciers both during (via supra-glacial emplacement of lava) and following effusive eruptions is difficult to quantify. Furthermore, a low degree of certainty is assigned to this calculation to reflect the generalised thickness estimates that are biased by outcrops at flow margins where lavas were impounded and overthickened against ice. Conversely, the recognition of 
ice-marginal flow emplacement improves the accuracy of the estimate by discounting the back-calculation of eruptive volumes inferred to have been lost via valley incision. Postglacial lava flows of the Whakapapa Formation were calculated to total $12 \mathrm{~km}^{3}$ in volume. This value has a higher degree of confidence than that given to volumes for pre-15 ka eruptive products due to the minimal post-emplacement erosion and burial of Whakapapa Formation lavas. The abnormally shallow and consistent slope gradient observed for the north-western flank of Ruapehu is considered to be the result of infilling of a deeper glaciated valley by debris avalanche deposits of the Murimotu Formation, upon which Iwikau package lavas were subsequently emplaced (Fig. 21).

The volume of Te Herenga Formation eruptive products is likely underestimated due to burial and limited exposure of the edifice constructed at $\sim 200-150 \mathrm{ka}$. The value of $\sim 28 \mathrm{~km}^{3}$ is significantly lower than previously determined $\left(65 \mathrm{~km}^{3}\right.$; Hackett and Houghton, 1989), which likely assumed a much greater body beneath the current composite volcano. Much of this buried volume may be able to be accounted for by earlier volcanic products (i.e. erupted between 340 and $200 \mathrm{ka}$ ). The revised volume estimate of $74 \mathrm{~km}^{3}$ for Wahianoa Formation eruptive products reported here is greater here than in previous studies because it incorporates lavas erupted during MIS 5 that are interpreted to be poorly preserved.

No lava flow eruption ages have yet been returned that lie within or $10 \mathrm{kyr}$ either side of MIS 4 (Fig. 16). Two hypotheses could explain this absence: 1) there was an eruptive hiatus, perhaps forced by loading of the edifice due to its voluminous growth over the previous $>100$ kyr and compounded by particularly voluminous ice cover centred on $60 \mathrm{ka}$; or 2) effusive activity continued but, due to extensive glaciation of the edifice, lava flows were not emplaced on flanks and were instead transported supra-glacially in fragments to the ring plain. Full glacial conditions in alpine regions during MIS 4 have been inferred from speleothem records (Williams et al., 2015), and extensive glaciation of Ruapehu is implied by 
exposure age dating of moraines on nearby Tongariro at $~ 60 \mathrm{ka}$ (Eaves, 2015). If lavas were either unable to break through a thick ice cap above eruptive vents or were erupted onto fully glaciated flanks with no emergent topography resulting in conveyance to the ring plain, they would not be recognised in the lava record on the Ruapehu edifice. Alternatively, the composition of lavas erupted during the following period of $\sim 48-35 \mathrm{ka}$ indicate that their source magmas underwent an extended period of differentiation, which may imply a preceding eruptive hiatus and suggest that the first hypothesis was also a factor.

Voluminous effusion occurred during glacial MIS 3 and 2, and continued into the current interglacial MIS 1 (Fig. 16). A central question to glaciovolcanic studies is whether glacial retreat after $\sim 20 \mathrm{ka}$ and the associated reduction of confining pressures on magma chambers led to increased rates of eruption in post-glacial times (Tuffen, 2010). Qualitative arguments for accelerated volcanic activity following deglaciation have been presented for Mazama in western USA (Bacon and Lanphere, 2006) and three Chilean volcanoes (Gardeweg et al., 1998; Singer et al., 2008; Mee et al., 2009). Approximately equal eruption rates have been calculated here for the syn- and post-glacial effusive periods, however, indicating that deglaciation did not lead to elevated volcanic activity at Ruapehu.

\section{Summary of the growth history of Ruapehu volcano}

The datasets acquired for this study are combined here with pre-existing data to outline the evolution of Ruapehu. This is summarised in a 10-stage development history.

1. Sub-glacial eruption and emplacement of Te Herenga Formation breccias and lavas occurred onto a pre-existing ice-capped edifice that had been active for the previous $\sim 140$ kyr. The vent-proximal section of this complex edifice is exposed at Pinnacle Ridge. Breccias 
were deposited in meltwater corridors and ice-marginal lava flows were emplaced on ice-free flanks and ridges extending north from the vent area from 200-150 ka.

2. Sub-glacial eruption of Wahianoa Formation breccias and dikes occurred prior to $166 \mathrm{ka}$. Ice-marginal emplacement of a voluminous lava flow and breccia sequence constructed the southeast planèze flank from 166-110 ka.

3. Eruptions of andesite lavas from a central vent onto an edifice with reduced ice mass continued from $\sim 100-80 \mathrm{ka}$. These lava flows were emplaced within glacially eroded valleys due to the reduction of flank glacier volumes during MIS 5.

4. An apparent eruptive hiatus and period of magma accumulation and fractionation occurred from $\sim 80-50 \mathrm{ka}$. The Ruapehu edifice was covered in ice during this time, corresponding to the advance of glaciers during MIS 4.

5. Eruption of andesite-dacite lava flows onto a glaciated edifice from $\sim 50-35$ ka resulted in ice-marginal emplacement of lava flows and construction of high planèzes and ridges on the mid-lower southern and western flanks of the edifice. Ice-dammed and ice-bounded flows were overthickened by $100-160 \mathrm{~m}$ at elevations of $1500 \mathrm{~m}$ a.s.l. Wide compositional ranges within individual eruptive packages and substantial effusion of dacite indicate that this eruptive period was preceded by magma storage and fractionation, as inferred above.

6. Effusive activity continued from $\sim 35-26 \mathrm{ka}$, with ice-marginal emplacement of lavas onto the glaciated edifice. The positions of ice-bounded flows indicate that ice cover during the last glacial period (MIS 4-2) was most extensive at $\sim 31 \mathrm{ka}$.

7. Eruption of lavas onto the glaciated Ruapehu edifice continued from $\sim 26-15 \mathrm{ka}$, with coeval explosive activity. Impoundment of flows occurred at lower elevations than during the preceding 20 kyrs and ice-bounded lava flows were thickened by up to $100 \mathrm{~m}$. 
8. Construction of glacially-bound summit cones and emplacement of upper flank lavas occurred between $~ 15-10 \mathrm{ka}$. Turoa, Paretetaitonga, and Tureiti cones were built adjacent to summit glaciers prior to $10 \mathrm{ka}$, atop steep topographic relief composed of altered ventproximal eruptive products.

9. Deglaciation resulted in destabilisation of the perched, ice-buttressed summit cones and led to a sector collapse event at $10.5 \mathrm{ka}$, yielding the Murimotu Formation debris avalanche deposit on the northern flank of Ruapehu. Iwikau package lava flows ( $<10 \mathrm{ka})$ were emplaced on top of the Murimotu Formation to the north and on the upper-mid eastern flank. The lavas form a cone that sits within the 10.5 ka collapse scar and is now filled by ice within the Summit Plateau.

10. Destabilisation and collapse of the southern summit cone, composed of Turoa package lavas resulted in another sector collapse event and deposition of the Mangaio Formation on eastern Ruapehu at $\sim 4.6 \mathrm{ka}$. Activity over at least the last $\sim 2 \mathrm{ka}$ has been focussed through Crater Lake within the scar of the collapsed southern cone. This activity has included the effusive eruption of Ruapehu's youngest andesite lava flow into the Whangaehu valley, the formation of the small-volume scoria cone surrounding the lake, and historic phreatomagmatic and lahar events.

\section{Conclusions}

The high-precision ${ }^{40} \mathrm{Ar} /{ }^{39} \mathrm{Ar}$ lava flow chronology and edifice growth history for Ruapehu presented provides a case study of the ice-affected construction of a Quaternary composite volcano. The major conclusions from this study that are relevant to other studies of glaciated composite volcanoes are as follows: 
- ${ }^{40} \mathrm{Ar} /{ }^{39} \mathrm{Ar}$ dating of the groundmass of andesite-dacite lava flows provides highprecision eruption age constraints with optimal 2 sd uncertainties of $1-2 \mathrm{kyr}$. The method was applied to Holocene lavas at Ruapehu, but the reduced level of precision due to low radiogenic Ar yields in such young, relatively low-K samples negates the nominal age determination for lavas younger than $5 \mathrm{ka}$.

- Eruption ages of lava flows that were emplaced against glaciers have been used in conjunction with mapping and exposure age dating of moraines to reconstruct past ice extents on Ruapehu. Constraints from glaciovolcanic products are particularly valuable as they have recorded the presence of valley-filling glaciers for periods when moraines were not constructed or preserved on Ruapehu.

- Contrary to previous studies of the geochemical evolution of Ruapehu lavas, new results indicate that magmas have not generally become more silicic over time. Following the wide geochemical diversity from $~ 50-35$ ka during which high-magnesian andesites and dacites were erupted, there has been a reversion to lower- $\mathrm{SiO}_{2}-\mathrm{K}_{2} \mathrm{O}$ magmas erupted since $\sim 26 \mathrm{ka}$.

- The retreat of flank glaciers and a summit ice cap has been presented in this study to have contributed to the destruction of two pre-Holocene summit cones and emplacement of the 10.5 ka Murimotu Formation debris avalanche deposit on northern Ruapehu. The new age constraints for the stratigraphic unconformities that immediately pre-date the sector collapse at Ruapehu show that deglaciation played a key role in generating sector collapse events, as may have occurred at other ice-clad composite volcanoes globally.

- This study has reiterated the difficulties of calculating accurate eruption rates for glaciated composite volcanoes. In particular, we note that volcanic products erupted during MIS 5 (130-71 ka) are likely to be underrepresented in volcanic stratigraphies because they have been buried within valleys or eroded by glaciers during MIS 4-2. The revised time- 
volume relationships for Ruapehu lavas presented here indicate that eruption rates did not increase as a result of ice unloading of the edifice during deglaciation since $\sim 18 \mathrm{ka}$.

\section{Acknowledgements}

This work was part-funded by Department of Conservation contract DOCDM-593774. CEC was supported by Victoria University of Wellington DVC Research Grant 13311. Field and laboratory support was provided by James Brigham-Watson, Jason Marshall and Kirsten Henden. The late John Watson of the Open University, UK, carried out the XRF analyses. Thanks alsoto James Saburomaru for help with Ar/Ar sample preparation at USGS. We are very grateful for constructive comments from Michelle Coombs, Roger Briggs and an anonymous reviewer.

\section{References}

Adams, C.J., Mortimer, N., Campbell, H.J., Griffin, W.L., 2009. Age and isotopic characteristics of metasedimentary rocks from the Torlesse Supergroup and Waipapa Group in the central North Island, New Zealand. New Zealand Journal of Geology and Geophysics 52, 149-170.

Bacon, C.R., Lanphere, M.A., 2006. Eruptive history and geochronology of Mount Mazama and the Crater Lake region, Oregon. Geological Society of America Bulletin 118, 13311359.

Calvert, A.T., Moore, R.B., McGimsey, R.G., 2005. Argon geochronology of late Pleistocene to Holocene Westdahl Volcano, Unimak Island, Alaska. In: Haeussler, P.J., Galloway, J.P. (Eds.), Studies by the U.S. Geological Survey in Alaska, 2004: US Geological Survey Professional Paper 1709-D, 1-16. 
Cameron, E., Gamble, J., Price, R., Smith, I., McIntosh, W., Gardner, M., 2010. The petrology, geochronology and geochemistry of Hauhungatahi volcano, S.W. Taupo Volcanic Zone. Journal of Volcanology and Geothermal Research 190, 179-191.

Capra, L., 2006. Abrupt climatic changes as triggering mechanisms of massive sector collapses. Journal of Volcanology and Geothermal Research 155, 329-333.

Capra, L., Benal, J.P., Carrasco-Nunez, G., Roverato, M., 2013. Climatic fluctuations as a significant contributing factor for volcanic collapses. Evidence from Mexico during the Late Pleistocene. Global and Planetary Change 100, 194-203.

Clark, P.U., Dyke, A.S., Shakun, J.D., Carlson, A.E., Clark, J., Wohlfarth, B., Mitrovica, J.X., 2009. The Last Glacial Maximum. Science 325, 710-714.

Clay, P.L., Buseman, H., Sherlock, S.C., Barry, T.L., Kelley, S.P., McGarvie, D.W., 2015. ${ }^{40} \mathrm{Ar} /{ }^{39} \mathrm{Ar}$ ages and residual volatile contents in degassed subaerial and subglacial volcanic rocks from Iceland. Chemical Geology 403, 99-110.

Coble, M.A., Grove, M., Calvert, A.T., 2011. Calibration of Nu-Instruments Noblesse multicollector mass spectrometers for argon isotopic measurements using a newly developed reference gas. Chemical Geology 290, 75-87.

Cole, J.W., 1978. Andesites of the Tongariro Volcanic Centre, North Island, New Zealand. Journal of Volcanology and Geothermal Research 3, 121-153.

Cole, J.W., Lewis, K.B., 1981. Evolution of the Taupo-Hikurangi subduction system. Tectonophysics 72, 1-21.

Conway, C.E., Townsend, D.B., Leonard, G.S., Wilson, C.J.N., Calvert, A.T., Gamble, J.A., 2015. Lava-ice interaction on a large composite volcano: a case study from Ruapehu, New Zealand. Bulletin of Volcanology 77, article 21.

Cossart, E., Braucher, R., Fort, M., Bourlès, D.L., Carcaillet, J., 2008. Slope instability in relation to glacial debuttressing in alpine areas (Upper Durance catchment, southeastern France): Evidence from field data and ${ }^{10} \mathrm{Be}$ cosmic ray exposure ages. Geomorphology 95, 3-26.

Cronin, S. J., Neall, V. E., 1997. A Late Quaternary stratigraphic framework for the northeastern Ruapehu and eastern Tongariro ring plains, New Zealand. New Zealand Journal of Geology and Geophysics 40, 185-197.

Dalrymple, G.B., 1989. The GLM continuous laser system for ${ }^{40} \mathrm{Ar} /{ }^{39} \mathrm{Ar}$ dating: description and performance characteristics. In Shanks, W.C., Criss, R.E. (Eds.), New Frontiers in Stable Isotopic Research. U.S. Geological Survey Bulletin 1890, 89-96. 
Dalrymple, G.B., Alexander, E.C., Lanphere, M.A., Kraker, G.P., 1981. Irradiation of samples for ${ }^{40} \mathrm{Ar} /{ }^{39} \mathrm{Ar}$ dating using the Geological Survey TRIGA reactor, U. S. Geological Survey Professional Paper 1176, 55 pp.

DeMets, C., Gordon, R.G., Argus, D.F., 2010. Geologically current plate motions: Geophysical Journal International 181, 1-80.Donoghue, S. L. Neall, V. E., 2001. Late Quaternary constructional history of the southeastern Ruapehu ring plain, New Zealand. New Zealand Journal of Geology and Geophysics 44, 439-466.

Donoghue, S.L., Neall, V.E., Palmer, A.S., 1995. Stratigraphy and chronology of Late Quaternary andesitic tephra deposits, Tongariro Volcanic Centre, New Zealand. Journal of the Royal Society of New Zealand 25, 115-206.

Donoghue, S.L., Neall, V.E., Palmer, A.S., Stewart, R.B., 1997. The volcanic history of Ruapehu during the past 2 millennia based on the record of Tufa Trig tephras. Bulletin of Volcanology 59, 136-146.

Dungan, M.A., Wulff, A., Thompson, R., 2001. Eruptive stratigraphy of the Tatara-San Pedro Complex, $36^{\circ} \mathrm{S}$, Southern Volcanic Zone, Chilean Andes: reconstruction method and implications for magma evolution at long-lived arc volcanic centres. Journal of Petrology 42, 555-626.

Eaves, S.R., 2015. The glacial history of Tongariro and Ruapehu volcanoes, New Zealand. $\mathrm{PhD}$ thesis, Victoria University of Wellington, New Zealand, $253 \mathrm{pp}$.

Eaves, S.R., Winckler, G., Schefer, J.M., Vandergoes, M.J., Alloway, B.V., Mackintosh, A.N., Townsend, D.B., Ryan, M.T., Li, X., 2015. A test of the cosmogenic ${ }^{3} \mathrm{He}$ production rate in the south-west Pacific $\left(39^{\circ} \mathrm{S}\right)$. Journal of Quaternary Science 30, 7987.

Eaves, S.R., Mackintosh, A.N., Anderson, B.M., Doughty, A.M., Townsend, D.B., Conway, C.E., Winckler, G., Schaefer, J.M., Leonard, G.S., Calvert, A.T., 2016a. The Last Glacial Maximum in the central North Island, New Zealand: paleoclimate inferences from glacier modelling. Climate of the Past 12, 943-960.

Eaves, S.R., Mackintosh, A.N., Winckler, G., Schaefer, J.M., Alloway, B.V., Townsend, D.B., 2016b. A cosmogenic ${ }^{3} \mathrm{He}$ chronology of Late Quaternary glacier fluctuations in North Island, New Zealand (39 ${ }^{\circ}$ S). Quaternary Science Reviews 132, 40-56.

Edwards, B.R., Gudmundsson, M.T., Russell, J.K., 2015. Glaciovolcanism. In: Sigurdsson, H., Houghton, B., Rymer, H., Stix, J., McNutt, S. (Eds.), Encyclopedia of Volcanoes, $2^{\text {nd }}$ Ed., Elsevier, Amsterdam, 377-393. 
Eichelberger, J.C., Izbekov, P.E., Browne, B.L., 2006. Bulk chemical trends at arc volcanoes are not liquid lines of descent. Lithos 87, 135-154.

Fierstein, J., Hildreth, W., Calvert, A.T., 2011. Eruptive history of South Sister, Oregon Cascades. Journal of Volcanology and Geothermal Research 207, 145-179.

Fleck, R.J., Hagstrum, J.T., Calvert, A.T., 2014. ${ }^{40} \mathrm{Ar} /{ }^{39} \mathrm{Ar}$ geochronology, paleomagnetism, and evolution of the Boring volcanic field, Oregon and Washington, USA. Geosphere 10, 1283-1314.

Frey, H. M., Lange, R. A., Hall, C. M., Delgado-Granados, H., 2004. Magma eruption rates constrained by ${ }^{40} \mathrm{Ar} /{ }^{39} \mathrm{Ar}$ chronology and GIS for the Ceboruco-San Pedro volcanic field, western Mexico. Geological Society of America Bulletin 116, 259-276.

Gamble, J.A., Wood, C.P., Price, R.C., Smith, I.E.M., Stewart, R.B., Waight, T., 1999. A fifty year perspective of magmatic evolution on Ruapehu Volcano, New Zealand: verification of open system behaviour in an arc volcano. Earth and Science Planetary Letters 170, 301-314.

Gamble, J.A., Price, R.C., Smith, I.E.M., McIntosh, W.C., Dunbar, N.W., 2003. ${ }^{40} \mathrm{Ar} /{ }^{39} \mathrm{Ar}$ geochronology of magmatic activity, magma flux and hazards at Ruapehu volcano, Taupo Volcanic Zone, New Zealand. Journal of Volcanology and Geothermal Research 120, 271-287.

Gardeweg, M.C., Sparks, R.S.J., Matthews, S.J., 1998. Evolution of Lascar volcano, Northern Chile. Journal of the Geological Society, London 155, 89-104.

Gill, J., 1981, Orogenic andesites and plate tectonics. Springer, Berlin, 390 pp.

Graham, I.J. Hackett, W.R., 1987. Petrology of calc-alkaline lavas from Ruapehu and related vents, Taupo Volcanic Zone, New Zealand. Journal of Petrology 28, 531-567.

Hackett, W.R., 1985. Geology and petrology of Ruapehu volcano and related vents. PhD thesis, Victoria University of Wellington, New Zealand, 467 pp.

Hackett, W.R., Houghton, B.F., 1985. Pinnacle Ridge Member, Whakapapa Formation: a welded airfall deposit from Ruapehu volcano, Taupo Volcanic Zone. New Zealand Geological Survey Record 8, 24-29.

Hackett, W.R., Houghton, B.F., 1989. A facies model for a Quaternary andesitic composite volcano, Ruapehu, New Zealand. Bulletin of Volcanology 51, 51-68.

Heine, A.J., 1963. Mount Ruapehu ice and snow survey. New Zealand Journal of Geology and Geophysics 6, 261-267.

Hickson, C.J., 2000. Physical controls and resulting morphological forms of Quaternary icecapped volcanoes in western Canada. Geomorphology 32, 239-261. 
Hildreth, W., Fierstein, J., 2012. Eruptive history of Mount Katmai, Alaska. Geosphere 8, 1527-1567.

Hildreth, W., Lanphere, M.A., 1994. Potassium-argon geochronology of a basalt-andesitedacite arc system: the Mount Adams volcanic field, Cascade Range of southern Washington. Geological Society of America Bulletin 106, 1413-1429.

Hildreth, W., Moorbath, S., 1988. Crustal contributions to arc magmatism in the Andes of Central Chile. Contributions to Mineralogy and Petrology 98, 455-489.

Hildreth, W. Fierstein, J., Lanphere, M.A., 2003a. Eruptive history and geochronology of the Mount Baker volcanic field, Washington. Geological Society of America Bulletin $115,729-764$.

Hildreth, W., Lanphere, M. A., Fierstein, J., 2003b. Geochronology and eruptive history of the Katmai volcanic cluster, Alaska Peninsula. Earth and Planetary Science Letters 214, 93-114.

Hora, J.M., Singer, B.S., Worner, G., 2007. Volcano evolution and eruptive flux on the thick crust of the Andean Central Volcanic Zone: ${ }^{40} \mathrm{Ar} /{ }^{39} \mathrm{Ar}$ constraints from Volcan Parinacota, Chile. Geological Society of America Bulletin 119, 343-362.

Houghton, B.F., Latter, J.H., Hackett, W.R., 1987. Volcanic hazard assessment for Ruapehu composite volcano, Taupo Volcanic Zone, New Zealand. Bulletin of Volcanology 49, 737-751.

Jicha, B. R., Singer, B. S., 2006. Volcanic history and magmatic evolution of Seguam Island, Aleutian Island arc, Alaska. Geological Society of America Bulletin 118, 805822.

Jicha, B.R., Coombs, M.L., Calvert, A.T., Singer, B.S., 2012. Geology and ${ }^{40} \mathrm{Ar} /{ }^{39} \mathrm{Ar}$ geochronology of the medium- to high-K Tanaga volcanic cluster, western Aleutians. Geological Society of America Bulletin 124, 842-856.

Kelley, S.E., Kaplan, M.R., Schaefer, J.M., Andersen, B.G., Barrell, D.J.A., Putnam, A.E., Denton, G.H., Schwartz, R., Finkel, R.C., Doughty, A.M, 2014. High-precision ${ }^{10}$ Be chronology of moraines in the Southern Alps indicates synchronous cooling in Antarctica and New Zealand 42,000 years ago. Earth and Science Planetary Letters 405, 194-206.

Kilgour, G., Blundy, J., Cashman, K., Mader, H.M., 2013. Small volume andesite magmas and melt-mush interactions at Ruapehu, New Zealand: evidence from melt inclusions. Contributions to Mineralogy and Petrology 166, 371-392. 
Lee, J.M., Townsend, D., Bland, K., Kamp, P.J.J. (compilers), 2011. Geology of the Hawke's Bay area. Institute of Geological \& Nuclear Sciences 1:250,000 geological map. Lower Hutt: Institute of Geological \& Nuclear Sciences Limited.

Lescinsky, D.T., Fink, J.H., 2000. Lava and ice interaction at stratovolcanoes: use of characteristic features to determine past glacial extents and future volcanic hazards. Journal of Geophysical Research 105, 23711-23726.

Lescinsky, D. T. Sisson, T. W., 1998. Ridge-forming, ice-bounded lava flows at Mount Rainier, Washington. Geology 26, 351-354.

Lisiecki, L. E., Raymo, M. E., 2005. A Pliocene-Pleistocene stack of 57 globally distributed benthic $\delta^{18} \mathrm{O}$ records. Paleoceanography 20, PA1003.

McArthur, J.L., Shepherd, M.J., 1990. Late Quaternary glaciation of Mt. Ruapehu, North Island, New Zealand. Journal of the Royal Society of New Zealand 20, 287-296.

McClelland, E., Erwin, P.S., 2003. Was a dacite dome implicated in the 9500 B.P. collapse of Mt Ruapehu? A paleomagnetic investigation. Bulletin of Volcanology 65, 294-305.

McGarvie, D.W., 2009. Rhyolitic volcano-ice interactions in Iceland. Journal of Volcanology and Geothermal Research 185, 367-389.

Mee, K., Gilbert, J.S., McGarvie, D.W., Naranjo, J.A., Pringle, M.S., 2009. Paleoenvironment reconstruction, volcanic evolution and geochronology of the Cerro Blanco subcomplex, Nevados de Chillán volcanic complex, central Chile. Bulletin of Volcanology 71, 933-952.

Nairn, I.A., Kobayashi, T., Nakagawa, M., 1998. The 10 ka multiple vent pyroclastic eruption sequence at Tongariro Volcanic Centre, Taupo Volcanic Zone, New Zealand: Part 1. Eruptive processes during regional extension. Journal of Volcanology and Geothermal Research 86, 19-44.

Nakagawa, M., Wada, K., Wood, C.P., 2002. Mixed magmas, mush chambers and eruption triggers: evidence from zoned clinopyroxene phenocrysts in andesitic scoria from the 1995 eruptions of Ruapehu volcano, New Zealand. Journal of Petrology 43, 2279-2303. Newnham, R.M., Eden, D.N., Lowe, D.J., Hendy, C.H., 2003. Rerewhakaaitu Tephra, a land-sea marker for the Last Termination in New Zealand, with implications for global climate change. Quaternary Science Reviews 22, 289-308.

Ownby, S., Granados, H.D., Lange, R.A., Hall, C.M., 2007. Volcán Tancítaro, Michoacán, ${ }^{40} \mathrm{Ar} /{ }^{39} \mathrm{Ar}$ constraints on its history of sector collapse. Journal of Volcanology and Geothermal Research 161, 1-14. 
Palmer, B.A., Neall. V.E., 1989. The Murimotu Formation - 9500 year old deposits of a debris avalanche and associated lahars, Mount Ruapehu, North Island, New Zealand. New Zealand Journal of Geology and Geophysics 32, 477-486.

Pardo, N., Cronin, S.J., Palmer, A.S., Németh, K., 2012. Reconstructing the largest explosive eruptions of Mt. Ruapehu, New Zealand: lithostratigraphic tools to understand subplinian-plinian eruptions at andesitic volcanoes. Bulletin of Volcanology 74, 617-640.

Pardo, N., Cronin, S.J., Wright, H.M.N., Schipper, C.I., Smith, I.E.M., Stewart, B., 2014. Pyroclast textural variation as an indicator of eruption column steadiness in andesitic Plinian eruptions at Mt. Ruapehu. Bulletin of Volcanology 76, article 822.

Price, R.C., Gamble, J.A., Smith, I.E.M., Stewart, R.B., Eggins, S. Wright, I.C., 2005. An integrated model for the temporal evolution of andesites and rhyolites and crustal development in New Zealand's North Island. Journal of Volcanology and Geothermal Research 140, 1-24.

Price, R.C., Gamble, J.A., Smith, I.E.M., Maas, R., Waight, T., Stewart, R.B., Woodhead, J., 2012. The anatomy of an andesite volcano: a time-stratigraphic study of andesite petrogenesis and crustal evolution at Ruapehu Volcano, New Zealand. Journal of Petrology 53, 2139-2189.

Price, R.C., Mortimer, N., Smith, I.E.M., Maas, R., 2015. Whole-rock geochemical reference data for Torlesse and Waipapa terranes, North Island, New Zealand. New Zealand Journal of Geology and Geophysics 58, 213-228.

Putnam, A.E., Schaefer, J.M., Denton, G.H., Barrell, D.J.A., Andersen, B.G., Koffman, T.N.B., Rowan, A.V., Finkel, R.C., Rood, D.H., Schwartz, R., Vandergoes, M.J., Plummer M.A., Brocklehurst S.H., Kelley, S.E., Ladig, K.L., 2013a. Warming and glacier recession in the Rakaia valley, Southern Alps of New Zealand, during Heinrich Stadial 1. Earth and Planetary Science Letters 382, 98-110.

Putnam, A.E., Schaefer, J.M., Denton, G.H., Barrell, D.J.A., Birkel, S.D., Andersen, B.G., Kaplan, M. R., Finkel, R. C., Schwartz, R., Doughty, A. M., 2013b. The Last Glacial Maximum at $44^{\circ} \mathrm{S}$ documented by a ${ }^{10} \mathrm{Be}$ moraine chronology at Lake Ohau, Southern Alps of New Zealand. Quaternary Science Reviews 62, 114-141.

Ramsey, M.H., Potts, P.J., Webb, P.C., Watkins, P., Watson, J.S. Coles, B.J., 1995. An objective assessment of analytical method precision: comparison of ICP-AES and XRF for the analysis of silicate rocks. Chemical Geology 124, 1-19. 
Reyners, M., Eberhart-Phillips, D., Stewart, G., Nishimura, Y., 2006. Imaging subduction from the trench to $300 \mathrm{~km}$ depth beneath the central North Island, New Zealand, with $V_{p}$ and $V_{p} / V_{s}$. Geophysical Journal International 165, 565-583.

Rivera, A., Bown, F., Mella, R., Wendt, J., Cassassa, G., Acuna, C., Rignot, E., Clavero, J., Brock, B, 2006. Ice volumetric changes on active volcanoes in southern Chile. Annals of Glaciology 43, 111-122.

Rother, H., Shulmeister, J., Fink, D., Alexander, D., Bell, D., 2015. Surface exposure chronology of the Waimakariri glacial sequence in the Southern Alps of New Zealand: implications for MIS-2 ice extent and LGM glacial mass balance. Earth and Planetary Science Letters 429, 69-81.

Russell, J.K., Edwards, B.R., Porritt, L., Ryane, C., 2014. Tuyas: a descriptive genetic classification. Quaternary Science Reviews 87, 70-81.

Schaefer, J.M., Putnam, A.E., Denton, G.H., Kaplan, M.R., Birkel, S., Doughty, A.M., Kelley, S., Barrell, D.J.A., Finkel, R.C., Winckler, G., Anderson, R.F., Ninneman, U.S., Barker, S., Schwartz, R., Andersen, B.G., Schleuter, C., 2015. The Southern Glacial Maximum 65,000 years ago and its unfinished termination. Quaternary Science Reviews $114,52-60$.

Schmidt, M.E., Grunder A.L., 2009. The evolution of North Sister: A volcano shaped by extension and ice in the central Oregon Cascade Arc. Geological Society of America Bulletin 121, 643-662.

Singer, B.S., Thompson, R.A., Dungan, M.A., Feeley, T.C., Nelson, S.T., Pickens, J.C., Brown, L. L., Wulff, A. W., 1997. Volcanism and erosion during the past $930 \mathrm{k} . \mathrm{y}$. at the Tatara-San Pedro complex, Chilean Andes. Geological Society of America Bulletin 109, 127-142.

Singer, B.S., Jicha, B.R., Harper, M.A., Naranjo, J.A., Lara, L.E., Moreano-Roa, H., 2008. Eruptive history, geochronology, and magmatic evolution of the Puyehue-Cordón-Caulle volcanic complex, Chile. Geological Society of America Bulletin 120, 599-618.

Skilling, I.P., 2009. Subglacial to emergent basaltic volcanism at Hlöðufell, south-west Iceland: A history of ice-confinement. Journal of Volcanology and Geothermal Research 185, 276-289.

Smellie, J.L., Rocchi, S., Gemelli, M., Di Vincenzo, G., Armienti, O., 2011. A thin predominantly cold-based Late Miocene East Antarctic ice sheet inferred from glaciovolcanic sequences in northern Victoria Land, Antarctica. Palaeogeography, Palaeoclimatology, Palaeoecology 307, 129-149. 
Smith, G.A., Grubensky, M.J., Geissman, J.W., 1999, Nature and origin of cone-forming volcanic breccias in the Te Herenga Formation, Ruapehu, New Zealand: Bulletin of Volcanology, v. 61, p. 64-82.

Spörli, K.B., Rowland, J.V., 2006. 'Column on column' structures as indicators of lava/ice interaction, Ruapehu andesite volcano, New Zealand. Journal of Volcanology and Geothermal Research 157, 294-310.

Stevenson, J.A., McGarvie, D.W., Smellie, J.L., Gilbert, J.S., 2006. Subglacial and icecontact volcanism at the Öræfajökull stratovolcano, Iceland. Bulletin of Volcanology 68, 737-752.

Stevenson, J.A., Smellie, J.L., McGarvie, D.W., Gilbert, J.S., Cameron, B.I., 2009.

Subglacial intermediate volcanism at Kerlingarfjoll, Iceland: magma-water interactions beneath thick ice. Journal of Volcanology and Geothermal Research 185, 337-351.

Tanaka, H., Kawamura, K., Nagao, K., Houghton, B.F., 1997. K-Ar ages and paleosecular variation of direction and intensity from Quaternary lava sequences in the Ruapehu volcano, New Zealand. Journal of Geomagnetism and Geoelectricity 49, 587-599.

Thouret, J.-C., Finizola, A., Fornari, M., Legeley-Padovani, A., Suni, J., Frechen, M., 2001. Geology of El Misti volcano near the city of Arequipa, Peru. Geological Society of America Bulletin 113, 1593-1610.

Tost, M., Cronin, S.J., 2015. Linking distal volcaniclastic sedimentation and stratigraphy with the development of Ruapehu volcano, New Zealand. Bulletin of Volcanology 77, article 94 .

Tost, M., Cronin, S.J., Procter, J.N., 2014. Transport and emplacement mechanisms of channelized long-runout debris avalanches, Ruapehu volcano, New Zealand. Bulletin of Volcanology 76, article 881.

Tost, M., Cronin, S.J., Procter, J.N., Smith, I.E.M., Neall, V.E., Price, R.C., 2015. Impacts of catastrophic volcanic collapse on the erosion and morphology of a distal fluvial landscape: Hautapu River, Mount Rupaehu, New Zealand. Geological Society of America Bulletin 127, 266-280.

Tuffen, H., 2010. How will melting of ice affect volcanic hazards in the twenty-first century? Philosophical Transactions of the Royal Society, London A368, 2535-2558.

Tuffen, H., Gilbert, J. McGarvie, D.W., 2001. Products of an effusive subglacial eruption: Bláhnúkur, Torfajökull, Iceland. Bulletin of Volcanology 63, 179-190. 
Villamor, P., Berryman, K.R., 2006a. Late Quaternary geometry and kinematics of faults at the southern termination of the Taupo Volcanic Zone, New Zealand. New Zealand Journal of Geology and Geophysics 49, 1-22.

Villamor, P., Berryman, K.R., 2006b. Evolution of the southern termination of the Taupo Rift, New Zealand. New Zealand Journal of Geology and Geophysics 49, 23-37.

Waight, T.E., Price, R.C., Smith, I.E.M., Stewart, R.B., Gamble, J.A., 1999. Stratigraphy and geochemistry of the Turoa region, with implications for andesite petrogenesis at Mt. Ruapehu, Taupo Volcanic Zone, New Zealand. New Zealand Journal of Geology and Geophysics 42, 513-532.

Williams, P.W., McGlone, M., Neil, H., Zhao, J.-X., 2015. A review of New Zealand paleoclimate from the Last Interglacial to the Last Glacial Maximum. Quaternary Science Reviews 110, 92-106.

Wilson, C.J.N., Houghton, B.F., McWilliams, M.O., Lanphere, M.A., Weaver, S.D., Briggs, R.M., 1995. Volcanic and structural evolution of Taupo Volcanic Zone, New Zealand: a review. Journal of Volcanology and Geothermal Research 68, 1-28.

Wilson, L., Head, J.W., 2007. Heat transfer in volcano-ice interactions on Earth. Annals of Glaciology 45, 83-86.

York, D., 1968. Least squares fitting of a straight line with correlated errors. Earth and Planetary Science Letters 5, 320-324. 


\section{Figure captions}

Fig. 1. Digital elevation model (DEM) map of the Tongariro Volcanic Centre (TgVC, red box on inset figure) at the southern end of the Taupo Volcanic Zone (TVZ) in North Island, New Zealand. Major faults (F) are marked in red. Inset map also shows the position of glaciated Southern Alps in South Island (grey shaded area). Key townships at Waiouru, Ohakune, National Park and Whakapapa Village are labelled. The major volcanic edifices in the map area are Hauhungatahi, Ruapehu and Tongariro. Major $<15$ ka vents are labelled with black stars.

Fig. 2. Index map for Ruapehu volcano, displaying major roads, river valleys and summit features referred to in the text. The major peaks of Tahurangi (Ta, $2797 \mathrm{~m})$, Paretetaitonga (Pa, 2662 m), Tukino (Tk), Te Heuheu (Th), Girdlestone (G), Pyramid Peak (Py) and Ringatoto (Ri) are marked with x symbols. Modern glaciers are numbered: Whakapapa (1); Mangaturuturu (2); Mangaehuehu (3); Wahianoa (4); Whangaehu (5); Mangatoetoenui (6). The summit also comprises the ice-filled Summit Plateau (SP) and active vent beneath Crater Lake (CL). Arrows indicate view directions for Figs. 5, 7, 11, 12 and 21. 
Fig. 3. Summary of the spatial and temporal distribution of effusive volcanic products at Ruapehu volcano that are described in this paper and shown in map view in Figs. 4, 9, 10 and 14. Key for eruptive packages of the Mangawhero and Whakapapa formations is displayed at right. Temporal ranges for packages and formations take into account $2 \sigma$ uncertainties of ${ }^{40} \mathrm{Ar} /{ }^{39} \mathrm{Ar}$ eruption ages for the relevant flows (Table 2).

Fig. 4. Distribution of Te Herenga Formation and Wahianoa Formation eruptive products. Locations for dated samples (open circles with sample numbers in italics) and relevant figures (cross or arrow, with bold numbers) are displayed. Sample locations for lavas dated by Gamble et al. (2003) that are referred to in this study are also displayed (squares with numbers with a ' $R$ ' prefix).

Fig. 5. View of the eroded Te Herenga Formation and post-glacial Whakapapa Formation lavas on the northern flank of Ruapehu. For location and azimuth of this view see Fig. 2. Distinct geographical features and elevations are marked in the top panel. Mapped extents of eruptive deposits are drawn in the bottom panel. Locations and eruption ages (weighted mean plateau ages: WMPA $\pm 2 \sigma$ ) of dated samples from this study are displayed. The location of the most mafic lava flow sampled on Ruapehu ('Ruapehu Basalt'; Price et al., 2012) is noted. Abbreviations are: WA (Wahianoa Formation); MN (Mananui package); SC (Saddle Cone package); PR (Pinnacle Ridge fall deposit); and the Iwikau (IW) and Taranaki Falls (TF) flow groups within the Iwikau package.

Fig. 6. Examples of eruptive products of the Te Herenga Formation. Locations of images are labelled in Fig. 4. (a) Hyaloclastite breccia unit exposed beneath Pinnacle Ridge is composed of dense, fresh lava within an orange palagonite matrix. (b) Breccia and 
laminated ash unit exposed on the northeast flank of the edifice. (c) Thick lavas located north of Pinnacle Ridge. Person circled for scale. (d) Characteristic pyroxene glomerocryst within a lava sample.

Fig. 7. View of the eastern side of Ruapehu volcano. For location and azimuth of this view see Fig. 2. Distinct geographical features are marked in the top panel. Mapped extents of eruptive products are drawn in the bottom panel. Locations and eruption ages (WMPA \pm $2 \sigma$ ) of dated samples from this study are displayed. Abbreviations are: MK (Makotuku package) and CL (Crater Lake package).

Fig. 8. Characteristic features of breccias and lava flows of the Wahianoa Formation. (a) Unconformity between voluminous mound of hyaloclastite breccia (hy) and lava flows, autobreccias and debris flows of the Wahianoa Formation (WA). Red circle shows position of Whangaehu Alpine Club hut. (b) Intrusion of lava (outlined by dashed lines) within hyaloclastite breccia. (c) Overthickened knuckle of lava (star) within sequence of alternating planar lava flows, autobreccias and debris flows on the true right bank of the Whangaehu River valley. (d) Platy jointed Wahianoa Formation andesite lava flow (WA; $88.2 \pm 6.4 \mathrm{ka}$ ) overlying debris flow deposits (df) in the Whangaehu River valley.

Fig. 9. Distribution of earlier Mangawhero Formation eruptive packages (50-35 ka). Locations for dated samples and relevant figures are displayed, as in Fig. 4. Girdlestone Peak is marked ' $G$ '.

Fig. 10. Distribution of later Mangawhero Formation eruptive packages (35-15 ka). Locations for dated samples and relevant figures are displayed, as in Fig. 4. Sample 
locations for lavas dated by Gamble et al. (2003) that are referred to in this study are also shown (squares with numbers with ' $X$ ' and ' $R$ ' prefixes).

Fig. 11. View of the Whakapapaiti valley on the northwest flank of Ruapehu volcano. For location and azimuth of this view see Fig. 2. Distinct geographical features are marked in the top panel. Mapped extents of eruptive units are drawn in the bottom panel. Locations and eruption ages $(\mathrm{WMPA} \pm 2 \sigma)$ of dated samples from this study are displayed.

Fig. 12. View of the northern ridge of the Mangaturuturu Valley on the western flank of Ruapehu. For location and azimuth of this view see Fig. 2. Elevations are marked in the top panel and mapped extents of eruptive units are drawn in the bottom panel. Locations and eruption ages (WMPA $\pm 2 \sigma$ ) of dated samples from this study are displayed. ME and MT are abbreviated labels for Mangaehuehu and Mangaturuturu packages, respectively.

Fig. 13. Features of Mangawhero Formation lavas. (a) Northward view toward Girdlestone Peak (G) showing multiple flows within the Mangaehuehu eruptive package (ME). (b) An ice-bounded Mangaturuturu eruptive package (MT) dacite lava overlies Ngahuinga eruptive package (NG) andesite lava and is capped by a younger moraine (m) on the western flank of Ruapehu. A lava flow of the Te Herenga Formation (TH) is exposed on the valley floor at the base of the ridge. (c) Column-forming joints on the margin of a Te Kohatu eruptive package ice-bounded dacite lava flow on northwest Ruapehu. Red circles are drawn around people separated by a distance of $\sim 15 \mathrm{~m}$. (d) Northeast-looking view toward Girdlestone (G) and Tahurangi (Ta) of lava flows and moraines. An ice-bounded lava of the Makotuku eruptive package (MK) with an age of $20.9 \pm 2.2 \mathrm{ka}$ (sample CC408) is overlain by moraines with $\sim 15-11 \mathrm{ka}^{3} \mathrm{He}$ exposure ages (Eaves, 2015). The locations of post-glacial 
Turoa eruptive package (TR) and Rangataua eruptive package (RT) lava flows are also displayed.

Fig. 14. Distribution of Whakapapa Formation eruptive products and debris avalanche deposits. Locations for dated samples and relevant figures are displayed, as in Fig. 4.

Fig. 15. Features of Whakapapa Formation package lavas. (a) Contact (dashed line) between $~ 26$ ka Whakapapaiti eruptive package dacite lavas (WH; orange) and overlying $\sim 15$ ka Paretetaitonga package andesite lavas (PT; dark). Star marks the position of an icebounded lava knuckle. (b) Exposure of the chilled base of an Iwikau package andesite lava flow with column-forming joints, which grades into baked till on the eastern Summit Plateau. (c) View of the western side of the summit reveals the collapse scars (dotted lines) inward of summit cones comprising Turoa (TR) and Paretetaitonga (PT) package lava flows. The collapsed southern cone has been infilled by eruptive products of the Crater Lake package (CL). (d) Fine-scale column-forming joints at the base of a glassy Turoa package andesite lava on southwest Ruapehu. Sledgehammer is $\sim 1 \mathrm{~m}$-long.

Fig. 16. Effusive history of Ruapehu volcano compared to the global $\delta^{18} \mathrm{O}$ record and marine isotope stages (MIS; Lisiecki and Raymo, 2005). ${ }^{40} \mathrm{Ar} /{ }^{39} \mathrm{Ar}$ ages are displayed for samples from this study (black diamonds) and Gamble et al. (2003; grey diamonds) with $2 \sigma$ uncertainties (bars).

Fig. 17. Ice extent at Ruapehu over the last $50 \mathrm{kyr}$. Glacier thicknesses are inferred from the height of dated ice-marginal lava flows above glaciated valley-floors and rounded to the nearest $10 \mathrm{~m}$. Samples are coloured according to their present-day elevation on the edifice. 
Shaded areas represent periods of glacial advance in New Zealand. The timing of cooling periods (a) and (b) is inferred from Southern Alps glacial moraines (Putnam et al., 2013a; Kelley et al., 2014) and speleothem records (Williams et al., 2015). The timing of period (c) corresponds to the global Last Glacial Maximum (Clark et al., 2009). The timing of period (d) is inferred from moraine records on Ruapehu and Tongariro volcanoes (Eaves, 2015).

Fig. 18. $\mathrm{SiO} 2$ and $\mathrm{K} 2 \mathrm{O}$ contents (weight \%) of Ruapehu lava flows plotted against ${ }^{40} \mathrm{Ar} /{ }^{39} \mathrm{Ar}$ age (ka). Eruption ages shown for samples from this study (black diamonds) and Gamble et al. (2003; grey diamonds). Error bars are $2 \sigma$ uncertainties of the eruption age measurements.

Fig. 19. $\mathrm{SiO}_{2}$ versus $\mathrm{MgO}$ (weight $\%$ ) diagram for 50-35 ka lava flows and $\sim 26 \mathrm{ka}$ Whakapapaiti package dacite. Open blue diamond is the dacite clast sample from the Murimotu Formation (Hackett, 1985). Lines of best fit define high- and low-MgO trends. Dotted lines correspond to the compositional gap for 50-35 ka lavas. Shaded fields indicate compositional ranges for pre-80 ka (i) and post-26 ka lavas (ii).

Fig. 20. $\mathrm{SiO}_{2}$ (weight \%) versus eruption age for Mangawhero and Whakapapa formation lava flows and pyroclastic deposits. Boxes represent $\mathrm{SiO}_{2}$ and age ranges for each eruptive package. Numbered bars represent whole-rock compositional ranges (data from Pardo et al., 2012) for pyroclasts from Plinian eruptions forming the: Mangatoetoenui Tephra (1); Shawcroft Tephra (2); Oruamata Tephra (3); Okupata-Pourahu Tephra (4). Whole-rock compositional range for pyroclasts from historical eruptions (grey bar) uses data from Gamble et al. (1999), Nakagawa et al. (2002) and Kilgour et al. (2013). 
Fig. 21. View of the northern flank of Ruapehu. For location and azimuth of this view see Fig. 2. The 10.5 ka Murimotu Formation debris avalanche deposit is inferred to have originated from collapse of pre-Holocene cones composed of Tureiti and Paretetaitonga eruptive packages. The sector collapse source area and pathway has been infilled and covered by Iwikau package andesite lava flows. Timing of emplacement of the lava flows is constrained by a measured eruption age of $6.0 \pm 2.4 \mathrm{ka} \mathrm{(sample} \mathrm{GL1030).}$ 
Table 1. Existing chronostratigraphic formations for Ruapehu volcano.

\begin{tabular}{|c|c|l|l|}
\hline Formation & Eruptive period & Sample & WMPA $\pm 2 \sigma(k a)$ \\
\hline Whakapapa & $<15 \mathrm{ka}$ & $\mathrm{n} / \mathrm{a}$ & $\mathrm{n} / \mathrm{a}$ \\
\hline Mangawhero & $60-15 \mathrm{ka}$ & $\mathrm{X} 1-6$ & $21 \pm 6$ \\
& & X1-16 & $22 \pm 7$ \\
& & $\mathrm{R} 99 / 1$ & $23 \pm 4$ \\
& & $\mathrm{R} 97 / 39$ & $23 \pm 8$ \\
& & $\mathrm{~T} 5-11$ & $45 \pm 6$ \\
& & $\mathrm{R}-\mathrm{S} 44-10$ & $47 \pm 4$ \\
\hline Wahianoa & $160-115 \mathrm{ka}$ & $\mathrm{R} 95 / 22$ & $119 \pm 12$ \\
& & $\mathrm{R} 96 / 5$ & $129 \pm 15$ \\
& & $\mathrm{R} 95 / 26$ & $130 \pm 23$ \\
& & $\mathrm{R} 96 / 16$ & $131 \pm 27$ \\
& & $\mathrm{R} 95 / 28$ & $133 \pm 11$ \\
& & $\mathrm{R} 96 / 17$ & $134 \pm 12$ \\
& & $\mathrm{R} 95 / 27$ & $135 \pm 14$ \\
& & $\mathrm{X} 1-10$ & $138 \pm 14$ \\
& & $\mathrm{R} 97-50$ & $147 \pm 10$ \\
& & $\mathrm{R} 96 / 9$ & $147 \pm 12$ \\
& & $\mathrm{R} 96 / 20$ & $154 \pm 12$ \\
\hline Te Herenga & $250-180 \mathrm{ka}$ & $\mathrm{T} 6-8$ & $183 \pm 13$ \\
& & $\mathrm{~T} 6-24$ & $197 \pm 12$ \\
& & $\mathrm{~T} 6-27$ & $205 \pm 27$ \\
\hline
\end{tabular}

${ }^{40} \mathrm{Ar} /{ }^{39} \mathrm{Ar}$ WMPA (weighted mean plateau age) and $2 \sigma$ uncertainty for lava flows measured by Gamble et al. (2003). Sample locations are displayed in Figs. 4, 9 and 10. 
Table 2. ${ }^{40} \mathrm{Ar} /{ }^{39} \mathrm{Ar}$ geochronology data for Ruapehu volcano lava flows.

\begin{tabular}{|c|c|c|c|c|c|c|c|c|}
\hline Sample & Fmtn-Package & $\mathbf{N}$ & ${ }^{39} \mathrm{Ar} \%$ & $\begin{array}{l}\text { Plateau age } \\
\text { MSWD }\end{array}$ & $(\mathrm{ka}, \pm 2 \sigma)$ & $\begin{array}{c}\text { Total gas age } \\
(\mathrm{ka}, \pm 2 \sigma)\end{array}$ & $\begin{array}{c}\text { Isochron age } \\
(\mathrm{ka}, \pm \mathbf{2 \sigma})\end{array}$ & $\begin{array}{c}{ }^{40} \mathbf{A r} /{ }^{36} \mathbf{A r}_{i} \\
( \pm 2 \sigma)\end{array}$ \\
\hline GL1983 & WH-Crater Lake & 6 & 79.8 & 1.06 & $0.2 \pm 2.2$ & $-1.8 \pm 2.2$ & $1.4 \pm 8.8$ & $294.3 \pm 9.9$ \\
\hline CC564 & WH-Iwikau & $\begin{array}{l}7 \\
1\end{array}$ & 86.0 & 0.67 & $0.8 \pm 5.6$ & $-0.8 \pm 5.6$ & $4 \pm 13.4$ & $293.3 \pm 9.5$ \\
\hline GL1030 & WH-Iwikau & 1 & 100.0 & 1.10 & $6.0 \pm 2.4$ & $6.5 \pm 2.4$ & $1.4 \pm 7.4$ & $298.4 \pm 5.2$ \\
\hline CC279 & WH-Iwikau & 6 & 63.9 & 0.79 & $8.8 \pm 2.8$ & $8.6 \pm 3.0$ & $10.5 \pm 17.2$ & $294.4 \pm 12.1$ \\
\hline CC569 & WH-Iwikau & 4 & 60.8 & 0.13 & $9.2 \pm 8.0$ & $-0.3 \pm 8.6$ & $22.2 \pm 47.8$ & $287.6 \pm 33.9$ \\
\hline CC236 & WH-Turoa & $\begin{array}{l}5 \\
1\end{array}$ & 62.7 & 0.61 & $11.9 \pm 2.2$ & $9.3 \pm 2.2$ & $15.4 \pm 15.2$ & $291.8 \pm 19.1$ \\
\hline CC393 & WH-Tureiti & 0 & 100.0 & 0.65 & $11.9 \pm 2.8$ & $12.3 \pm 2.8$ & $11.9 \pm 8.8$ & $295.4 \pm 6.9$ \\
\hline CC397 & WH-Tureiti & 7 & 83.9 & 0.90 & $12.5 \pm 2.6$ & $10.2 \pm 2.6$ & $14.4 \pm 5.0$ & $293.2 \pm 6.0$ \\
\hline CC335 & WH-Paretetaitonga & $\begin{array}{l}7 \\
1\end{array}$ & 79.8 & 0.80 & $14.8 \pm 3.0$ & $22.1 \pm 3.0$ & $10.8 \pm 12.4$ & $299.5 \pm 14.7$ \\
\hline $\mathrm{CC} 130$ & WH-Turoa & $\begin{array}{l}1 \\
1\end{array}$ & 100.0 & 0.46 & $15.1 \pm 2.4$ & $15.2 \pm 2.4$ & $13.9 \pm 6.0$ & $296.3 \pm 2.9$ \\
\hline $\mathrm{CC} 226$ & MA-Makotuku & 0 & 100.0 & 0.34 & $17.8 \pm 2.2$ & $18.1 \pm 2.6$ & $16.8 \pm 4.2$ & $296.7 \pm 5.2$ \\
\hline $\mathrm{CC} 408$ & MA-Makotuku & $\begin{array}{l}8 \\
1\end{array}$ & 94.7 & 0.39 & $20.9 \pm 2.8$ & $19.6 \pm 3.0$ & $22.7 \pm 7.4$ & $293.9 \pm 7.3$ \\
\hline CC143 & MA-Waitonga & 0 & 99.5 & 0.80 & $23.0 \pm 1.6$ & $23.0 \pm 1.8$ & $22.2 \pm 4.6$ & $296.4 \pm 5.7$ \\
\hline CC513 & MA-Whakapapaiti & 3 & 67.9 & 0.50 & $25.7 \pm 3.8$ & $6.7 \pm 4.4$ & $39.4 \pm 28.6$ & $265.6 \pm 72.9$ \\
\hline $\mathrm{CC} 441$ & MA-Manganuioteao & $\begin{array}{l}6 \\
1\end{array}$ & 86.6 & 1.34 & $25.7 \pm 2.6$ & $20.3 \pm 2.8$ & $34.1 \pm 8.2$ & $286.6 \pm 9.9$ \\
\hline CC553 & MA-Manganuioteao & 0 & 100.0 & 0.40 & $27.2 \pm 4.8$ & $25.8 \pm 5.8$ & $29.0 \pm 7.2$ & $294.0 \pm 3.2$ \\
\hline CC547 & MA-Manganuioteao & 6 & 72.6 & 0.77 & $30.7 \pm 5.2$ & $43.9 \pm 4.6$ & $28.6 \pm 10.4$ & $296.6 \pm 21.5$ \\
\hline $\mathrm{CC} 462$ & MA-Manganuioteao & 9 & 94.6 & 0.54 & $30.9 \pm 2.2$ & $30.4 \pm 2.6$ & $30.8 \pm 5.4$ & $295.6 \pm 6.4$ \\
\hline CC508 & MA-Te Kohatu & 3 & 57.4 & 1.11 & $37.6 \pm 1.4$ & $46.2 \pm 1.4$ & $37.8 \pm 21.8$ & $294.4 \pm 109.2$ \\
\hline CC556 & MA-Ngahuinga & $\begin{array}{l}7 \\
1\end{array}$ & 90.8 & 0.53 & $38.3 \pm 3.4$ & $30.0 \pm 4.0$ & $37.9 \pm 8.4$ & $295.9 \pm 13$ \\
\hline $\mathrm{CC} 414$ & MA-Te Kohatu & 1 & 100.0 & 1.78 & $39.1 \pm 1.4$ & $40.7 \pm 1.4$ & $36.5 \pm 2.0$ & $302.2 \pm 5.1$ \\
\hline CC511 & MA-Te Kohatu & $\begin{array}{l}9 \\
1\end{array}$ & 97.7 & 0.44 & $39.2 \pm 2.0$ & $40.2 \pm 2.4$ & $38.4 \pm 3.6$ & $297.3 \pm 9.9$ \\
\hline $\mathrm{CC} 424$ & MA-Ngahuinga & 0 & 100.0 & 0.96 & $39.6 \pm 2.8$ & $40.3 \pm 3.2$ & $38.6 \pm 5.2$ & $296.2 \pm 4.0$ \\
\hline CC570 & MA-Mananui & 8 & 91.7 & 0.28 & $40.3 \pm 2.2$ & $37.7 \pm 2.6$ & $41.7 \pm 3.6$ & $291.5 \pm 9.6$ \\
\hline CC545 & MA-Mangaturuturu & 8 & 91.6 & 1.33 & $38.4 \pm 2.4$ & $35.9 \pm 2.6$ & $40.7 \pm 4.6$ & $290.0 \pm 10.9$ \\
\hline $\mathrm{CC} 470$ & MA-Mangaturuturu & $\begin{array}{l}9 \\
1\end{array}$ & 99.4 & 0.96 & $41.3 \pm 1.8$ & $41.2 \pm 2.0$ & $42.9 \pm 4.2$ & $292.9 \pm 6.7$ \\
\hline $\mathrm{CC} 140$ & MA-Mangaehuehu & 1 & 100.0 & 0.52 & $41.8 \pm 1.8$ & $41.2 \pm 2.0$ & $44.6 \pm 4.0$ & $293.3 \pm 3.3$ \\
\hline $\mathrm{CC} 313$ & MA-Te Kohatu & 4 & 70.5 & 1.73 & $42.6 \pm 1.8$ & $39.5 \pm 1.4$ & $49.6 \pm 7.0$ & $273.3 \pm 25.8$ \\
\hline $\mathrm{CC} 127$ & MA-Mangaehuehu & $\begin{array}{l}8 \\
1\end{array}$ & 84.4 & 0.66 & $42.8 \pm 1.0$ & $43.9 \pm 1.0$ & $42.9 \pm 2.2$ & $295.1 \pm 5.9$ \\
\hline $\mathrm{CC} 216$ & MA-Mangaehuehu & $\begin{array}{l}2 \\
1\end{array}$ & 100.0 & 1.32 & $43.1 \pm 1.4$ & $43.8 \pm 1.4$ & $41.5 \pm 2.6$ & $298.1 \pm 4.3$ \\
\hline CC119 & MA-Mangaehuehu & 1 & 100.0 & 1.46 & $43.3 \pm 1.6$ & $42.6 \pm 1.6$ & $45.3 \pm 2.4$ & $292.7 \pm 3.1$ \\
\hline CC552 & MA-Mangaturuturu & 6 & 91.8 & 0.68 & $43.4 \pm 2.4$ & $45.1 \pm 3.0$ & $41.9 \pm 6.0$ & $300.0 \pm 20.7$ \\
\hline $\mathrm{CC} 081$ & MA-Mangaehuehu & 8 & 86.7 & 1.17 & $44.2 \pm 1.8$ & $46.8 \pm 1.8$ & $41.9 \pm 6.2$ & $300.6 \pm 15.6$ \\
\hline $\mathrm{CC} 453$ & MA-Ngahuinga & 8 & 96.7 & 1.43 & $44.8 \pm 3.0$ & $45.4 \pm 2.8$ & $45.8 \pm 5.8$ & $294.3 \pm 5.9$ \\
\hline $\mathrm{CC} 089$ & MA-Mangaehuehu & 9 & 96.9 & 1.72 & $45.4 \pm 2.0$ & $46.0 \pm 1.6$ & $47.2 \pm 8.0$ & $293.2 \pm 10.2$ \\
\hline CC562 & WA & $\begin{array}{l}6 \\
1\end{array}$ & 83.7 & 0.51 & $88.1 \pm 6.4$ & $85.2 \pm 9.0$ & $85.0 \pm 19.4$ & $296.9 \pm 10.5$ \\
\hline $\mathrm{CC} 350$ & WA & 0 & 100.0 & recoil & $95.9 \pm 7.0$ & $95.5 \pm 4.2$ & $98.6 \pm 16.8$ & $293.8 \pm 9.3$ \\
\hline CC209 & WA & 9 & 98.9 & 0.75 & $120.7 \pm 4.0$ & $119.5 \pm 5.0$ & $123.6 \pm 5.4$ & $293.8 \pm 2.5$ \\
\hline $\mathrm{CC} 213$ & WA & 4 & 54.2 & 1.25 & $121.4 \pm 2.8$ & $122.2 \pm 2.4$ & $123.7 \pm 16.0$ & $292.2 \pm 25.2$ \\
\hline CC375 & WA & 7 & 89.2 & 1.64 & $121.7 \pm 4.2$ & $119.6 \pm 3.4$ & $125.8 \pm 9.8$ & $292.2 \pm 9.2$ \\
\hline $\mathrm{CC} 197$ & WA & $\begin{array}{l}9 \\
1\end{array}$ & 97.2 & 0.72 & $133.6 \pm 6.4$ & $136.0 \pm 6.8$ & $138.1 \pm 13.6$ & $293.6 \pm 5.7$ \\
\hline CC518 & $\mathrm{TH}$ & 0 & 100.0 & 0.36 & $158.8 \pm 8.2$ & $157.6 \pm 9.6$ & $158.9 \pm 13.4$ & $295.3 \pm 7.5$ \\
\hline CC322 & $\mathrm{TH}$ & $\begin{array}{l}9 \\
1\end{array}$ & 99.1 & 2.02 & $169.4 \pm 7.8$ & $171.0 \pm 6.0$ & $176.4 \pm 17.2$ & $291.0 \pm 10.7$ \\
\hline $\mathrm{CC} 276$ & $\mathrm{TH}$ & 0 & 94.5 & 0.86 & $174.6 \pm 3.4$ & $171.0 \pm 5.8$ & $169.2 \pm 7.2$ & $300.9 \pm 7.3$ \\
\hline $\mathrm{CC} 348$ & $\mathrm{TH}$ & 7 & 81.5 & 1.00 & $186.2 \pm 6.8$ & $173.1 \pm 7.2$ & $203.3 \pm 22.4$ & $287.7 \pm 11.5$ \\
\hline CC306 & $\mathrm{TH}$ & 1 & 100.0 & recoil & $187.9 \pm 34.4$ & $146.6 \pm 11.4$ & $207.5 \pm 22.2$ & $289.8 \pm 2.9$ \\
\hline
\end{tabular}


Formation abbreviations are: WH (Whakapapa); MA (Mangawhero); WA (Wahianoa); TH (Te Herenga). $\mathrm{N}$ is number of heating steps, $\%^{39} \mathrm{Ar}$ is the proportion of released radiogenic gas, and MSWD is the mean standard weighted deviation of each age plateau calculation. Bold numbers are the preferred ages for each sample, which are all mean weighted plateau ages, except for CC545 where the isochron age was preferred. See Electronic Appendix 2 for age spectra for all samples. 
Table 3. Summary of the compositional ranges for eruptive packages.

\begin{tabular}{|c|c|c|c|c|}
\hline Formation & Eruptive package & $\mathrm{SiO}_{2}$ & $\mathbf{K}_{2} \mathbf{O}$ & Mg\# \\
\hline Whakapapa & $\begin{array}{c}\text { Crater Lake }^{\#} \\
\text { Iwikau } \\
\text { Saddle Cone* } \\
\text { Tureiti } \\
\text { Paretetaitonga } \\
\text { Rangataua } \\
\text { Turoa }\end{array}$ & $\begin{array}{c}61 \\
57-59 \\
56-59 \\
60 \\
57-59 \\
59-60 \\
59-60\end{array}$ & $\begin{array}{c}2.2 \\
1.2-1.6 \\
1.2-1.7 \\
1.7-1.8 \\
1.5-1.7 \\
1.7-1.8 \\
1.5-2.0\end{array}$ & $\begin{array}{c}55 \\
50-60 \\
53-56 \\
48 \\
51-56 \\
48 \\
50-60\end{array}$ \\
\hline Mangawhero & $\begin{array}{c}\text { Makotuku } \\
\text { Waitonga } \\
\text { Te Piripiri } \\
\text { Horonuku* } \\
\text { Whakapapaiti } \\
\text { Manganuioteao } \\
\text { Mananui } \\
\text { Te Kohatu } \\
\text { Mangaturuturu } \\
\text { Mangaehuehu } \\
\text { Ngahuinga }\end{array}$ & $\begin{array}{c}60-62 \\
61-63 \\
58-60 \\
60-62 \\
65 \\
60-63 \\
64 \\
64-65 \\
63-64 \\
57-62 \\
57-61 \\
\end{array}$ & $\begin{array}{c}1.8-2.1 \\
1.8-2.0 \\
1.4-1.9 \\
1.8-1.9 \\
2.1 \\
1.9-2.6 \\
2.8 \\
2.9-3.3 \\
2.7-3.0 \\
1.4-2.3 \\
1.6-2.1\end{array}$ & $\begin{array}{c}44-50 \\
51-58 \\
56-60 \\
54-60 \\
57 \\
45-52 \\
50 \\
54-57 \\
42-45 \\
60-69 \\
48-58 \\
\end{array}$ \\
\hline Wahianoa & undifferentiated & $56-60$ & $0.9-1.7$ & $42-62$ \\
\hline Te Herenga & undifferentiated & $54-57$ & $0.7-0.9$ & $51-62$ \\
\hline
\end{tabular}

Range of $\mathrm{SiO}_{2}$ and $\mathrm{K}_{2} \mathrm{O}$ contents and $\mathrm{Mg \#}[100 \mathrm{Mg} /(\mathrm{Mg}+\mathrm{Fe})]$ shown. Composition for Crater Lake ${ }^{\#}$ is based on the dated lava flow (GL1983). Compositional ranges for Saddle Cone* and Horonuku* packages are constrained by data from Price et al. (2012). 
Table 4. Volumes and eruptive rates for global examples of arc composite volcanoes.

\begin{tabular}{|lcccl|}
\hline Volcano & Volume $\left(\mathbf{k m}^{\mathbf{3}}\right)$ & Duration $(\mathbf{k y r})$ & Avg rate $\left.\mathbf{( k m}^{\mathbf{3}} \mathbf{k a}^{\mathbf{- 1}}\right)$ & Reference \\
\hline Mt Baker (stratocone) & 15 & 43 & 0.35 & Hildreth et al., 2003a \\
Parinacota & 46 & 160 & 0.28 & Hora et al., 2007 \\
Tatara-San Pedro & 55 & 930 & 0.06 & Singer et al., 1997 \\
El Misti & 70 & 112 & 0.63 & Thouret et al., 2001 \\
Katmai & 70 & 89 & 0.79 & Hildreth et al., 2003b \\
Puyehue & 80 & 320 & 0.25 & Singer et al., 2008 \\
Seguam & 80 & 320 & 0.25 & Jicha and Singer, 2006 \\
Ceboruco-San Pedro & 81 & 810 & 0.1 & Frey et al., 2004 \\
Tanaga & 90 & 300 & 0.3 & Jicha et al., 2012 \\
Mt Adams (stratocone) & 200 & 520 & 0.38 & Hildreth and Lanphere, 1994 \\
\hline Ruapehu & & & & \\
Te Herenga Formation & 28 & 50 & 0.56 & \\
Wahianoa Formation & 74 & 60 & 1.23 & \\
Mangawhero Formation & 28 & 35 & 0.8 & \\
Whakapapa Formation & 12 & 15 & 0.8 & \\
\hline
\end{tabular}

References for global examples indicated in table. Revised volumes, durations and eruptive rates for Ruapehu formations in this study are defined here. 


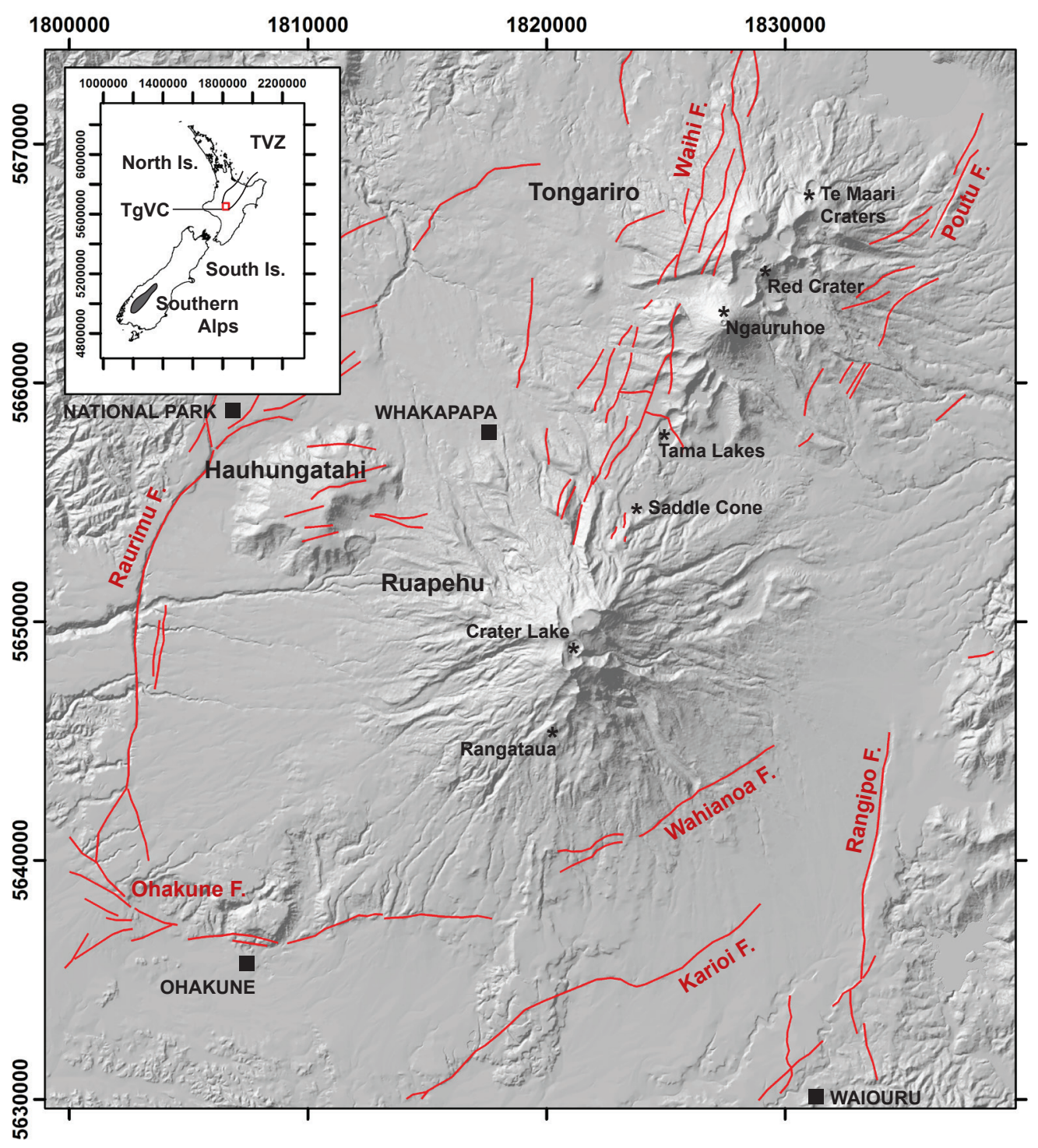




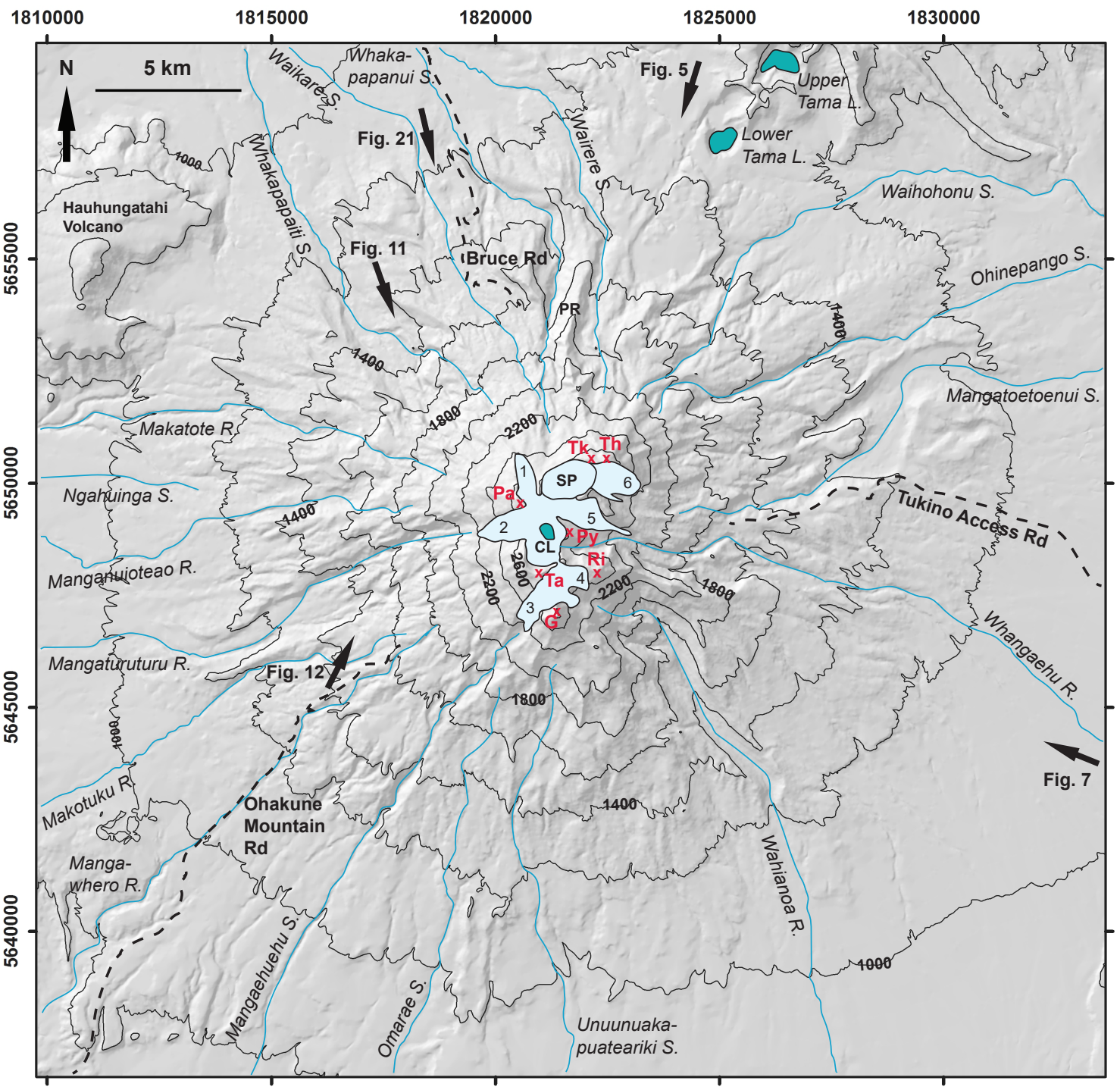




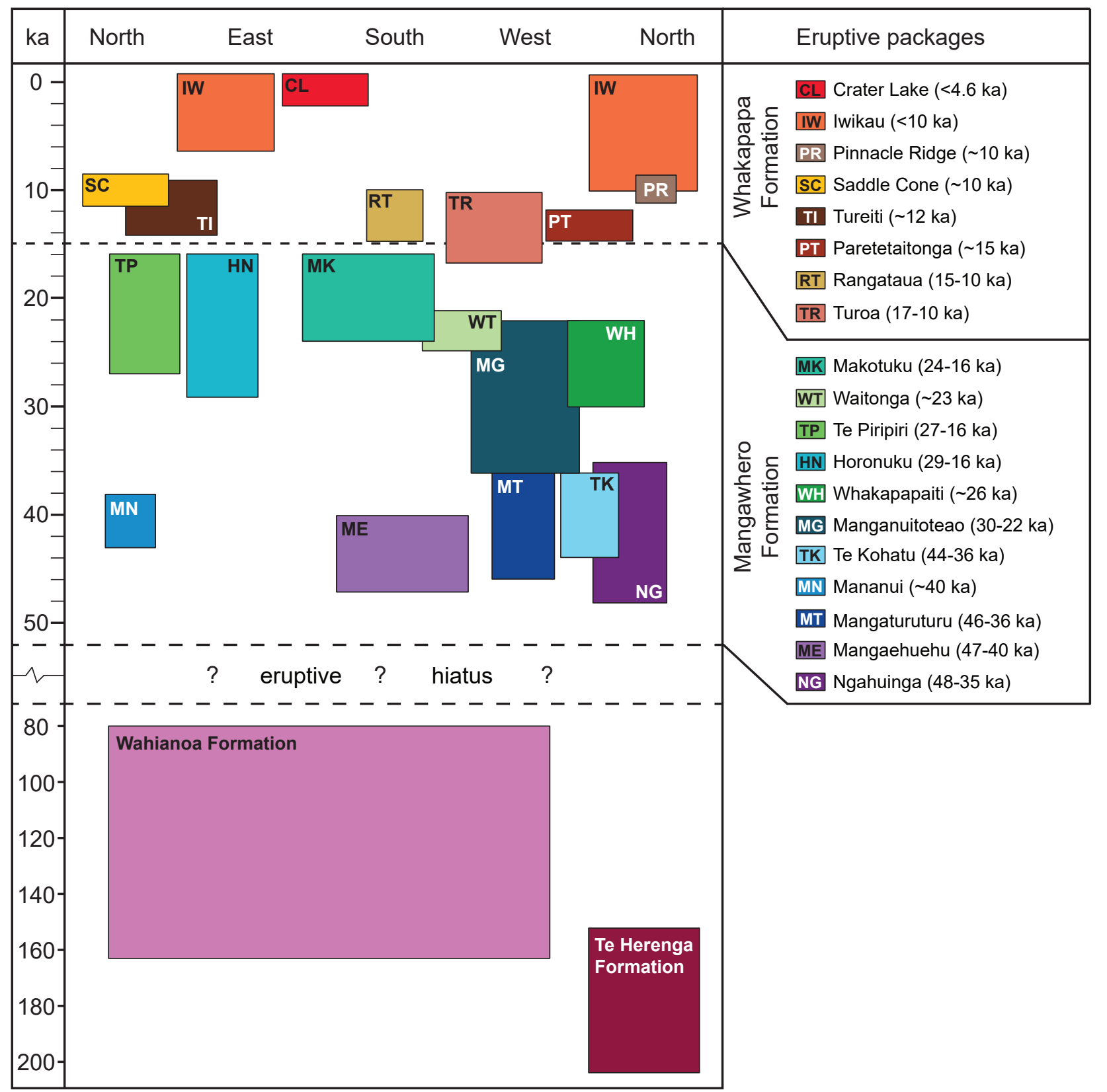




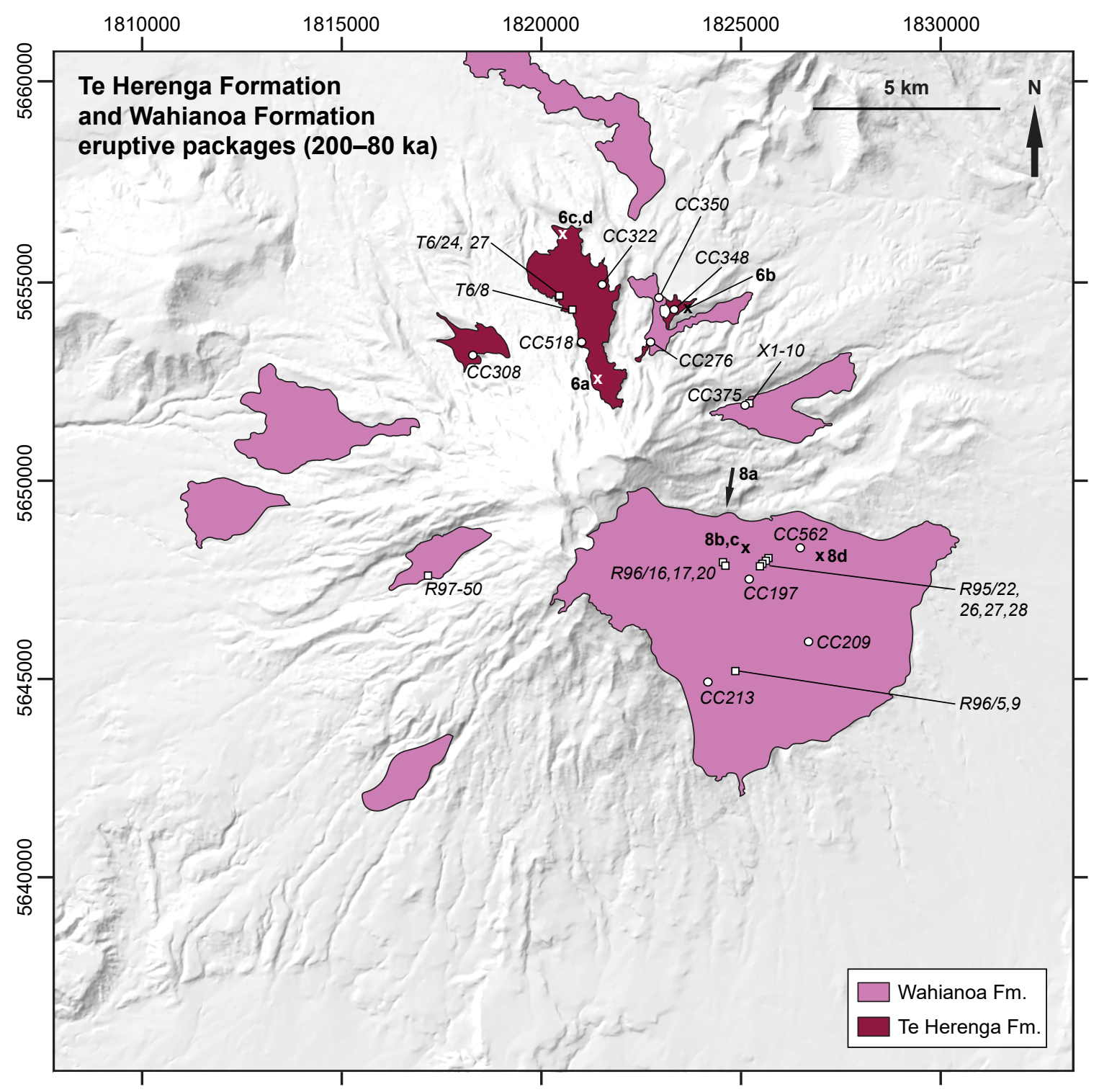




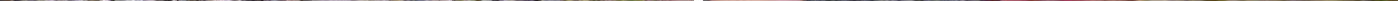



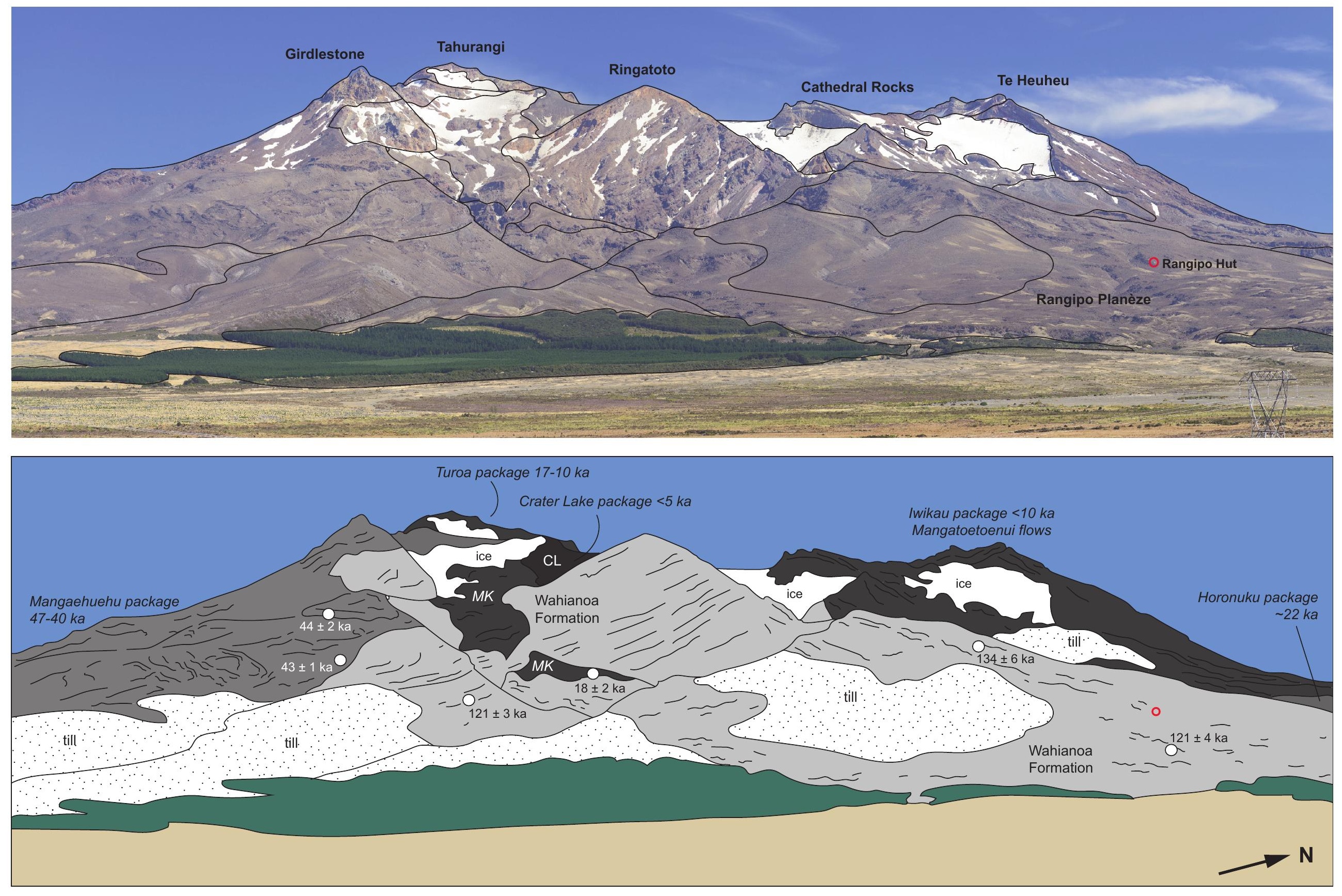


\section{a}

$\times \sqrt{b}=e^{2}-1-0$

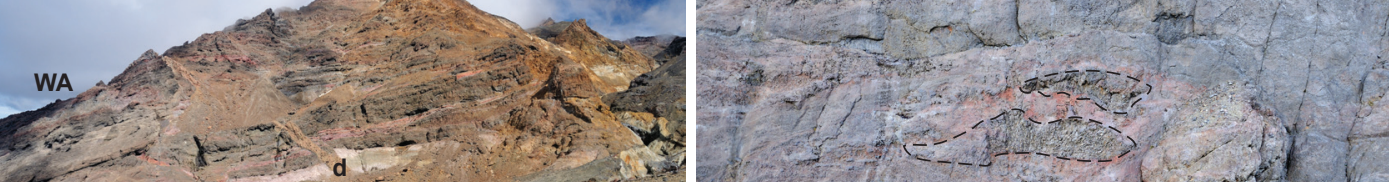

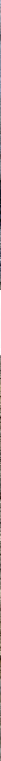




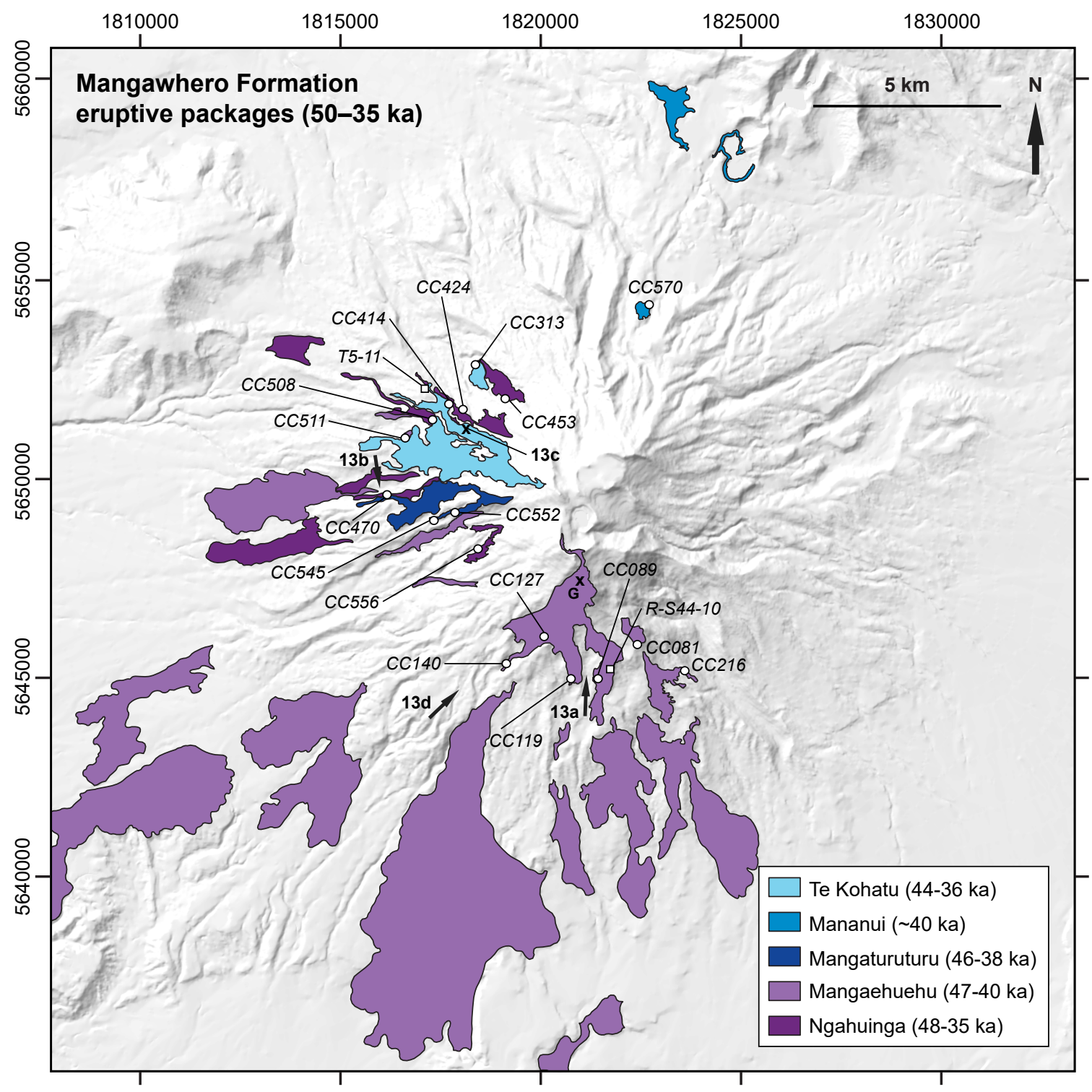




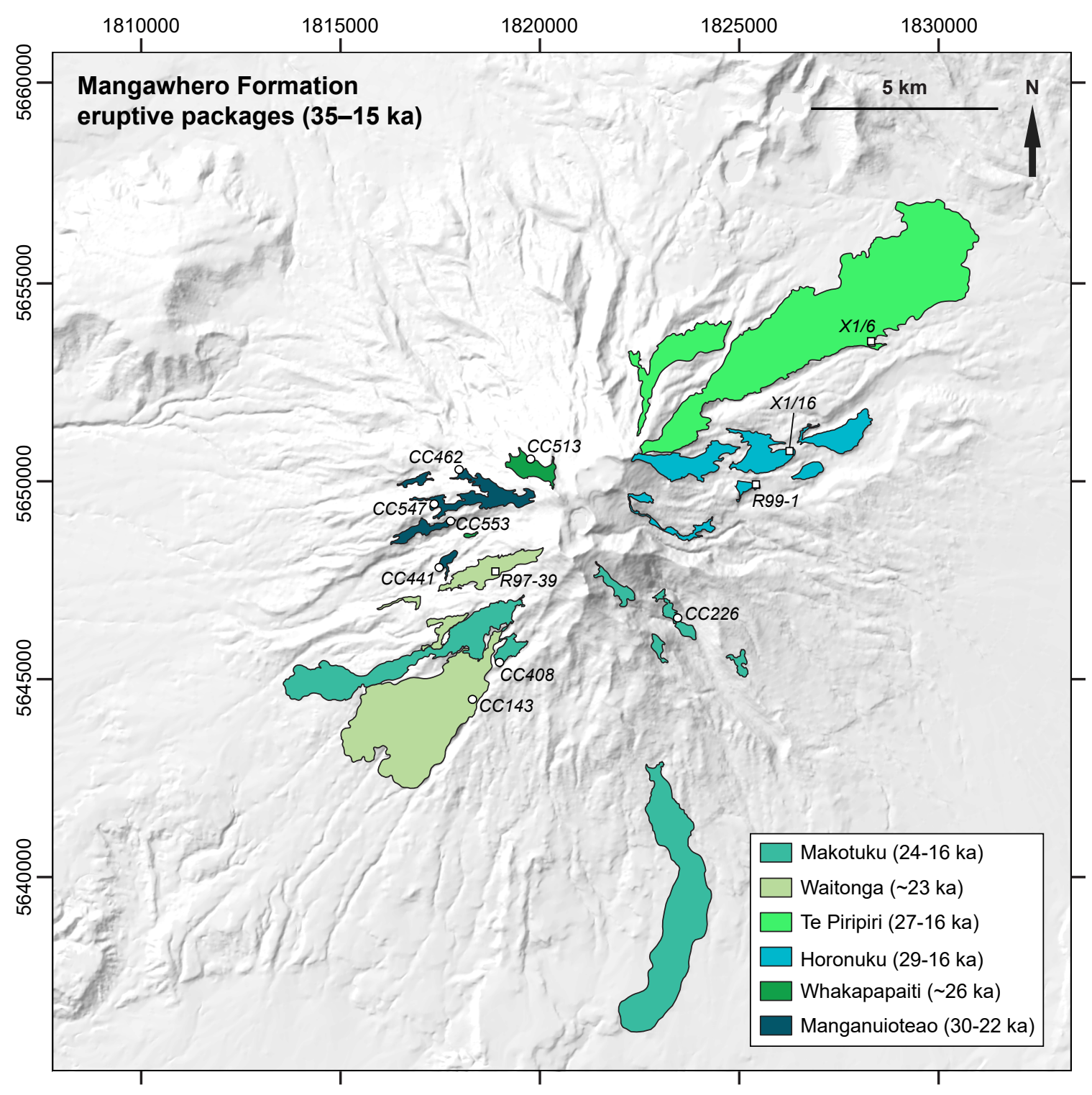



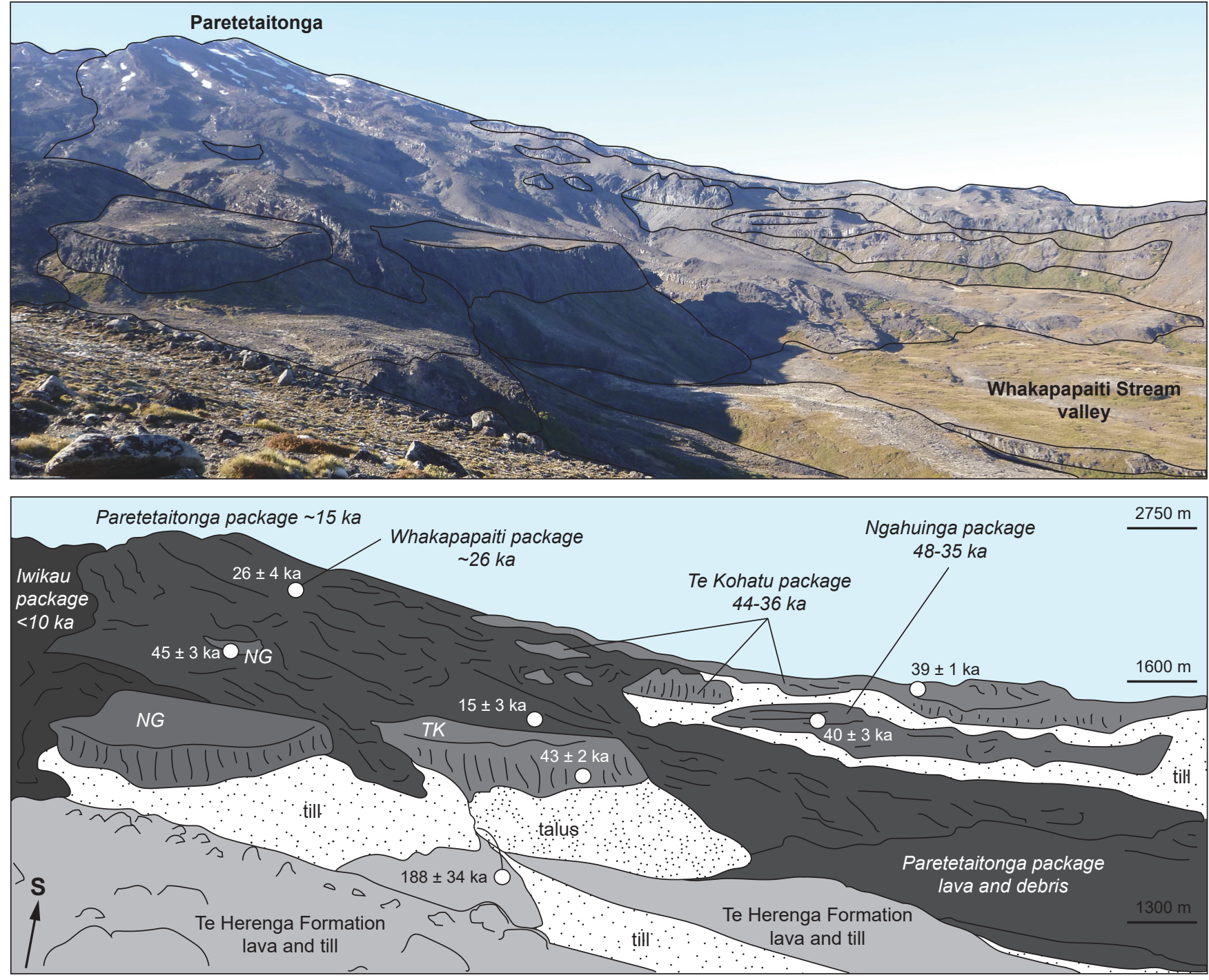


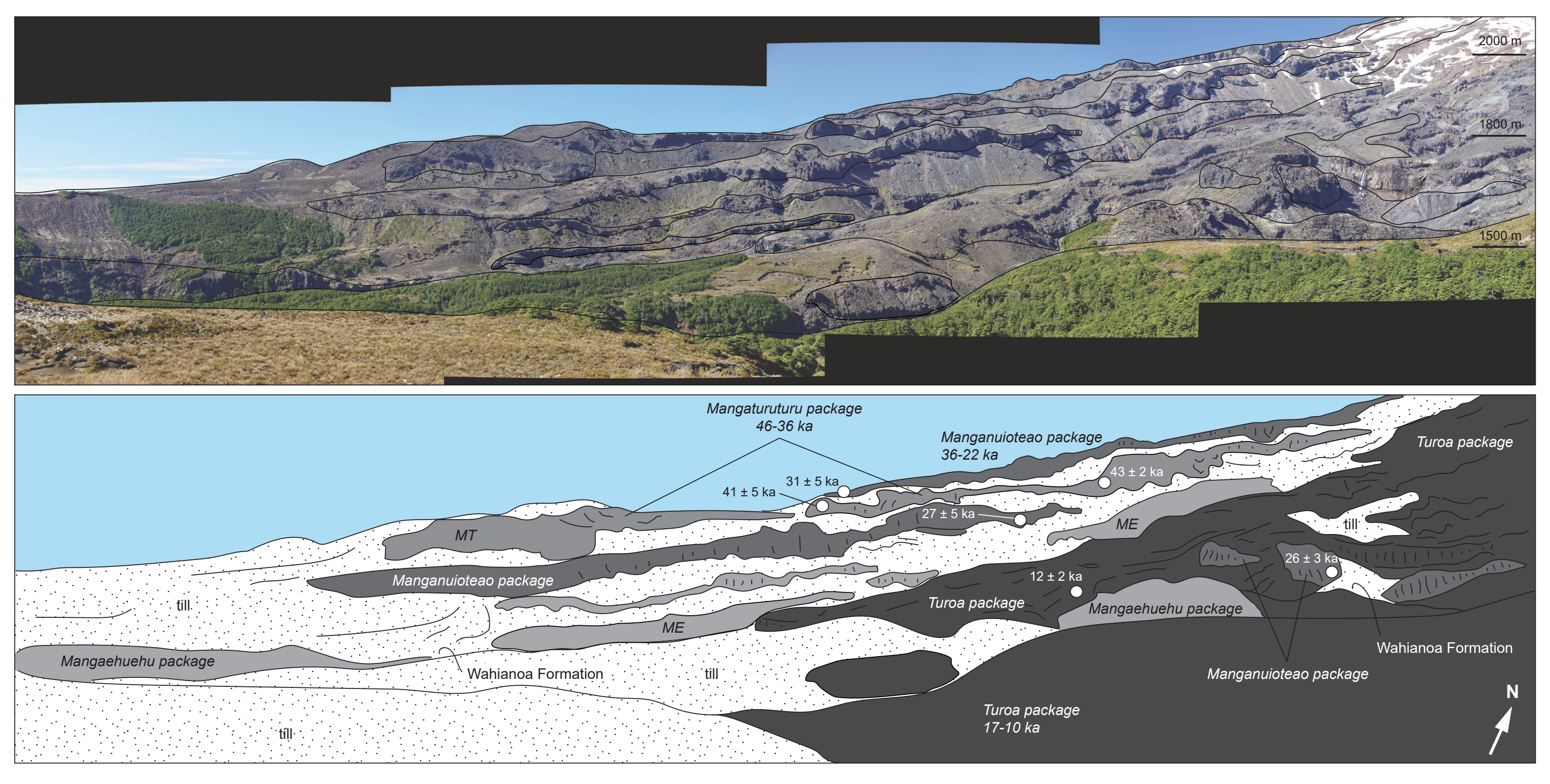




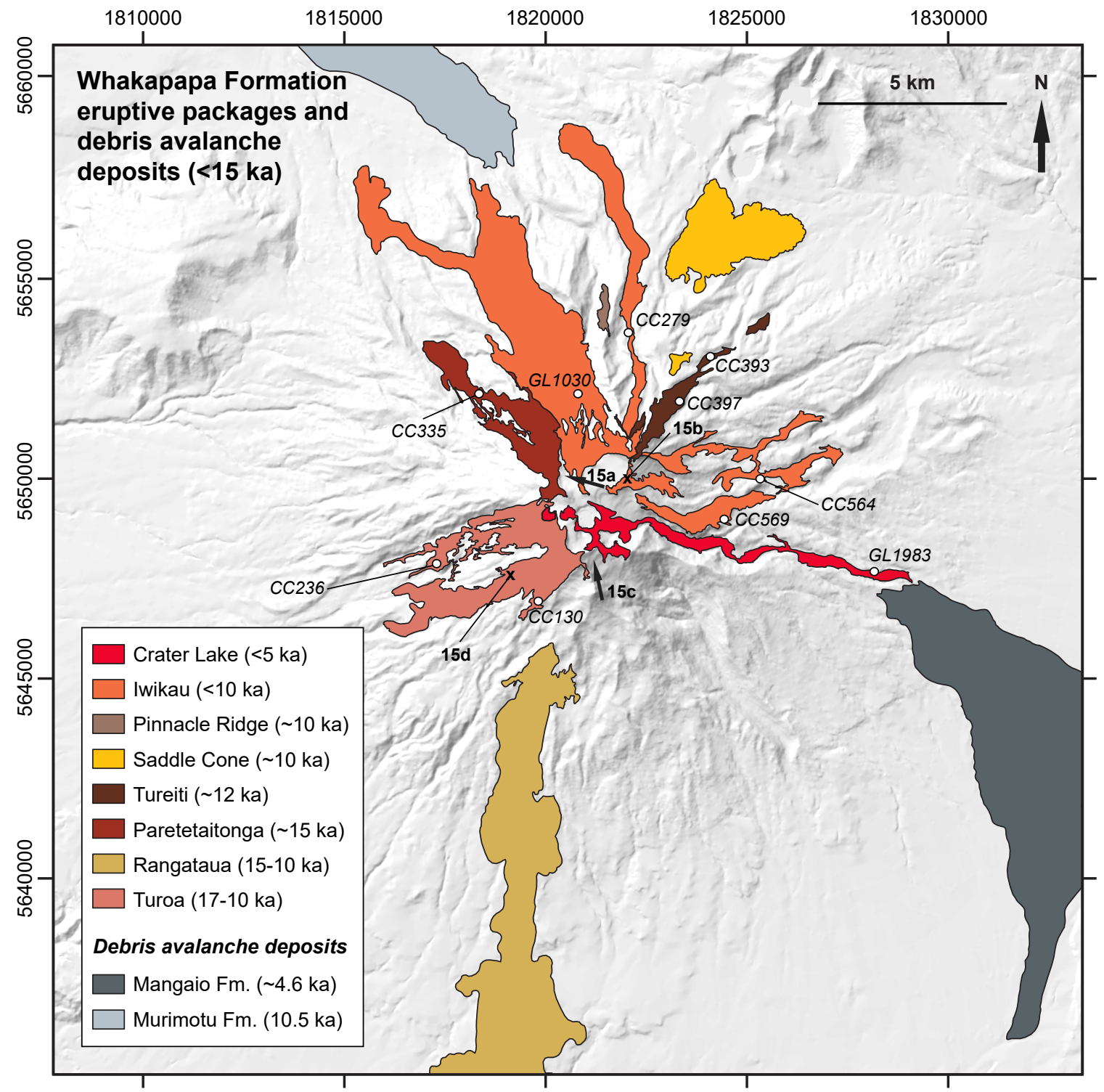


b

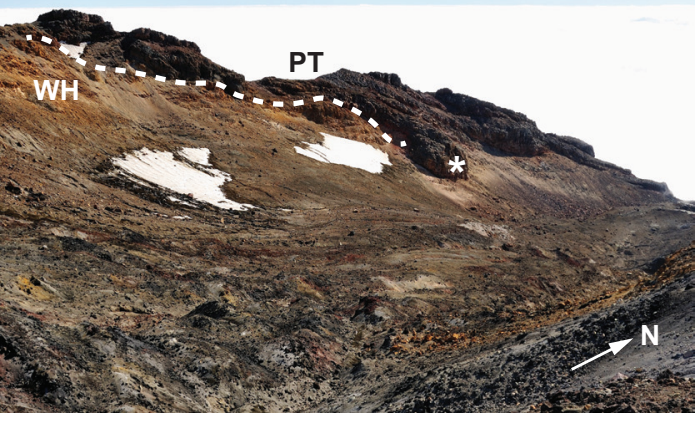

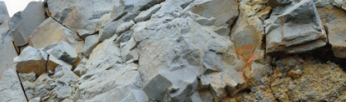

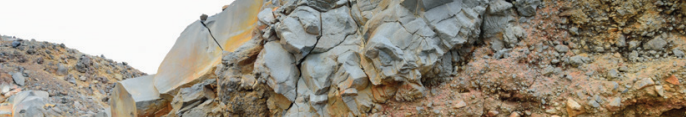

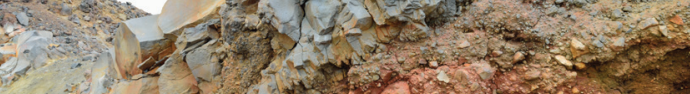

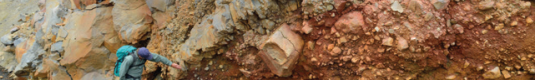

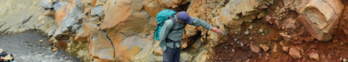

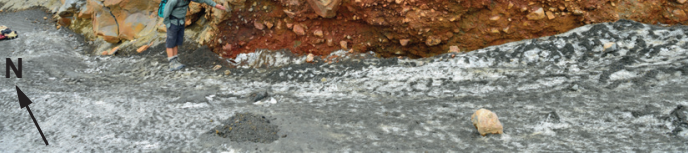

C

.

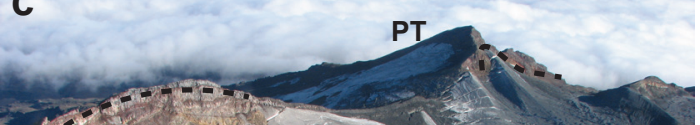

TF

,

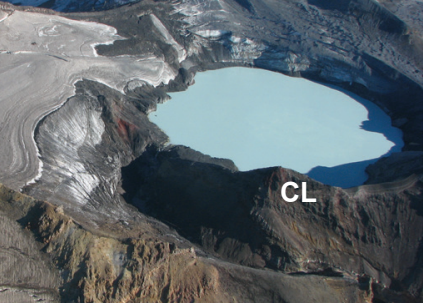

$\mathbf{N}$

X. है

2. $8.019 \%$

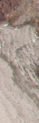

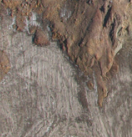

CL

$x^{2}-10 x^{2}$

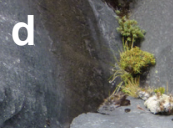

sery $3 y^{2}$
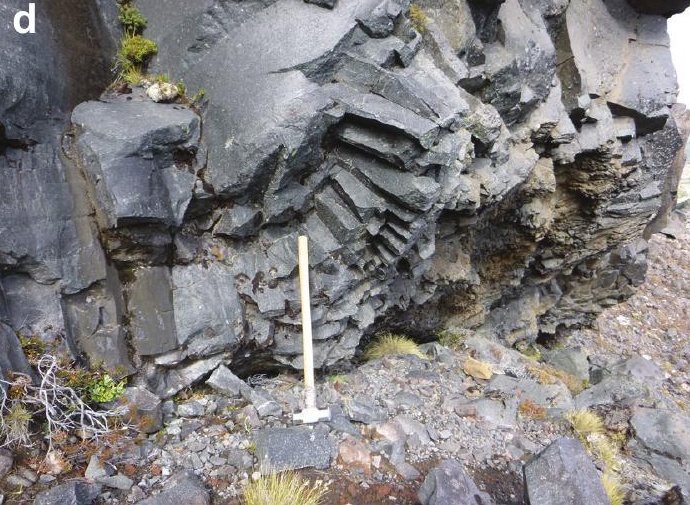


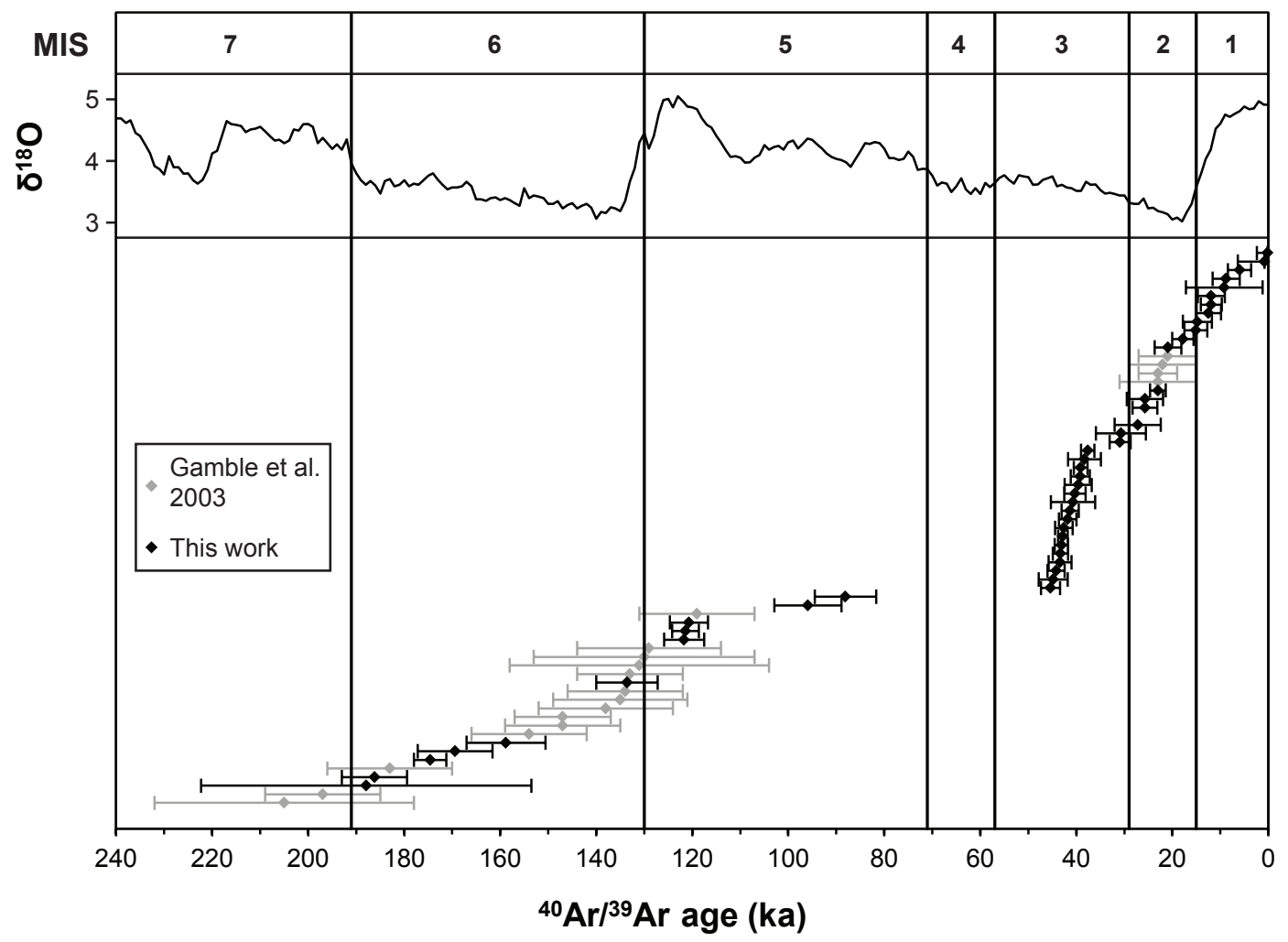




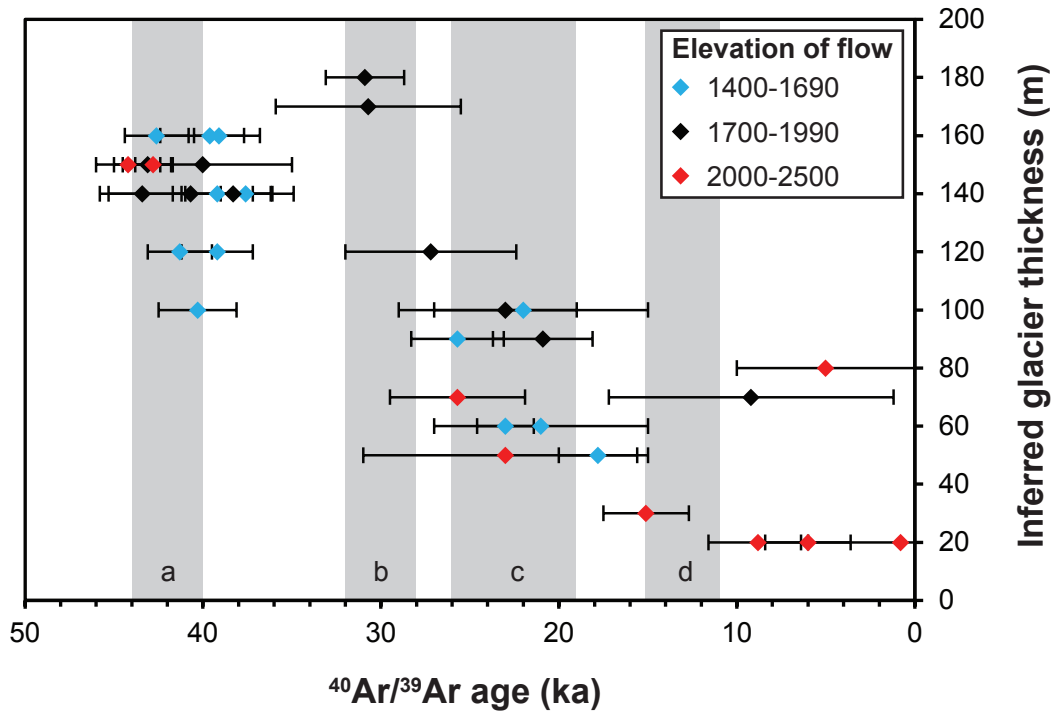




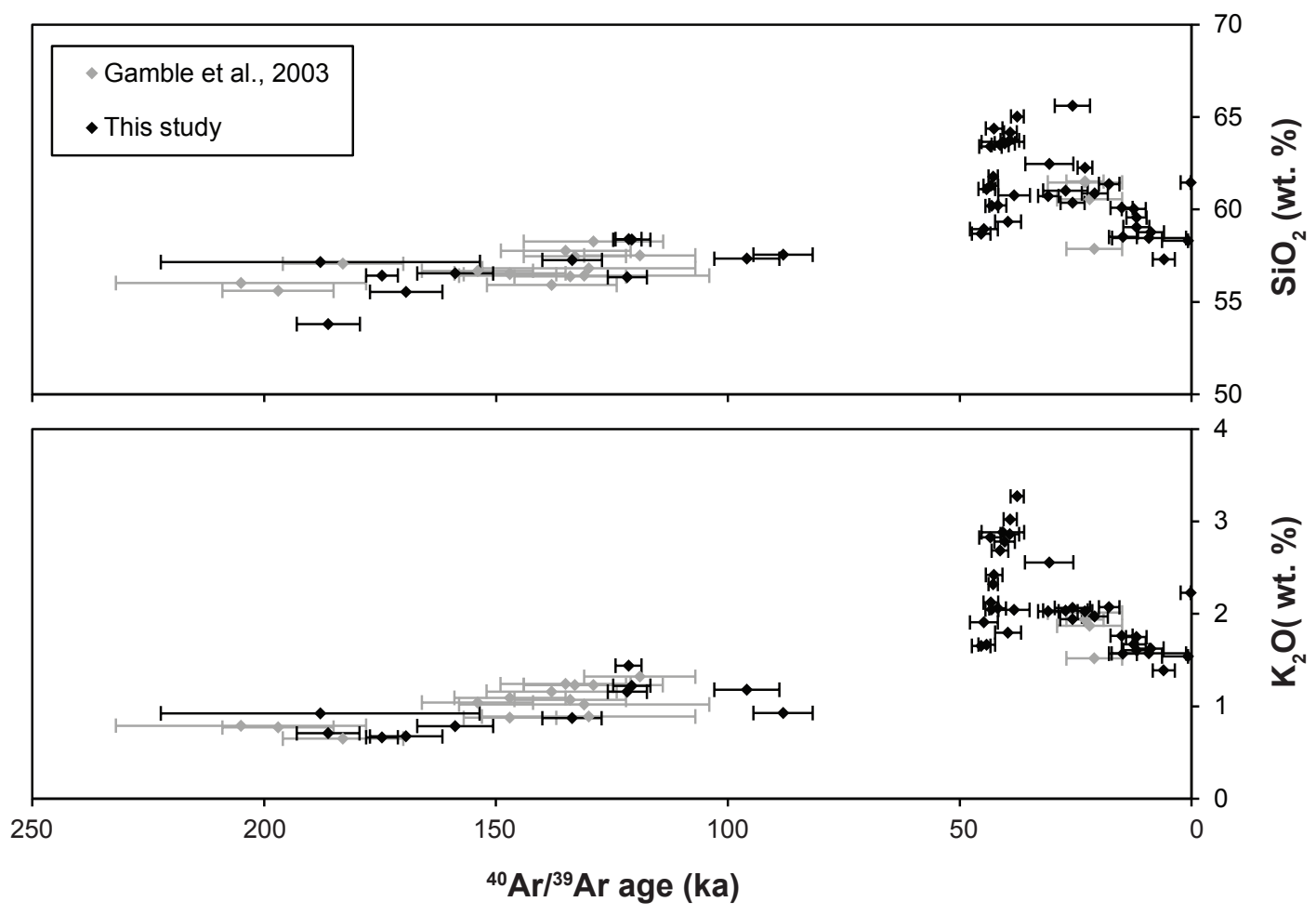




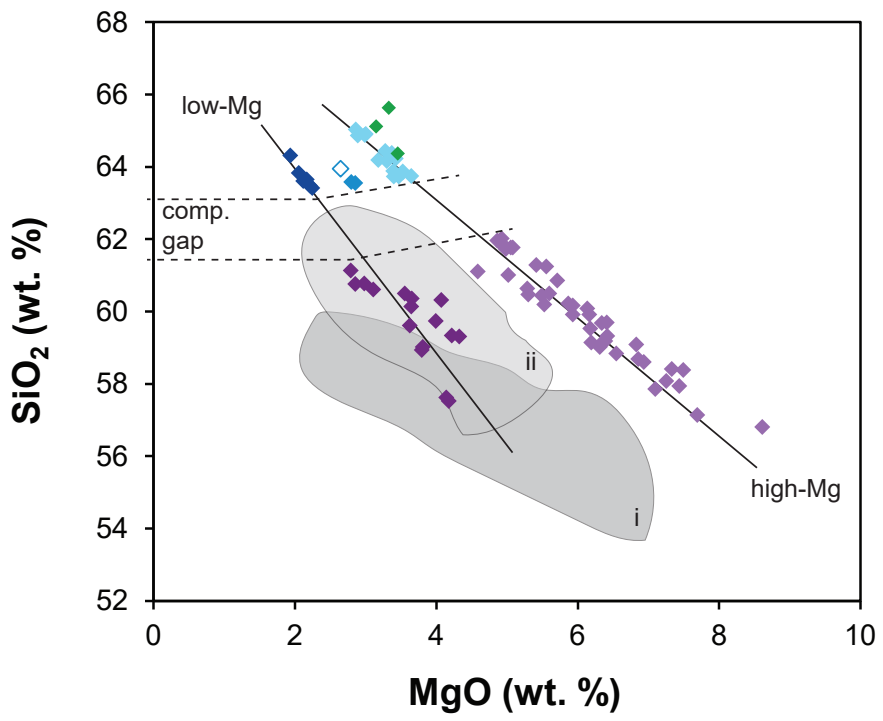

- Whakapapaiti ( 26 ka)

Te Kohatu (44-36 ka)

- Mananui ( 40 ka)
- Mangaturuturu (46-38 ka)

- Mangaehuehu (47-40 ka)

- Ngahuinga (48-35 ka) 


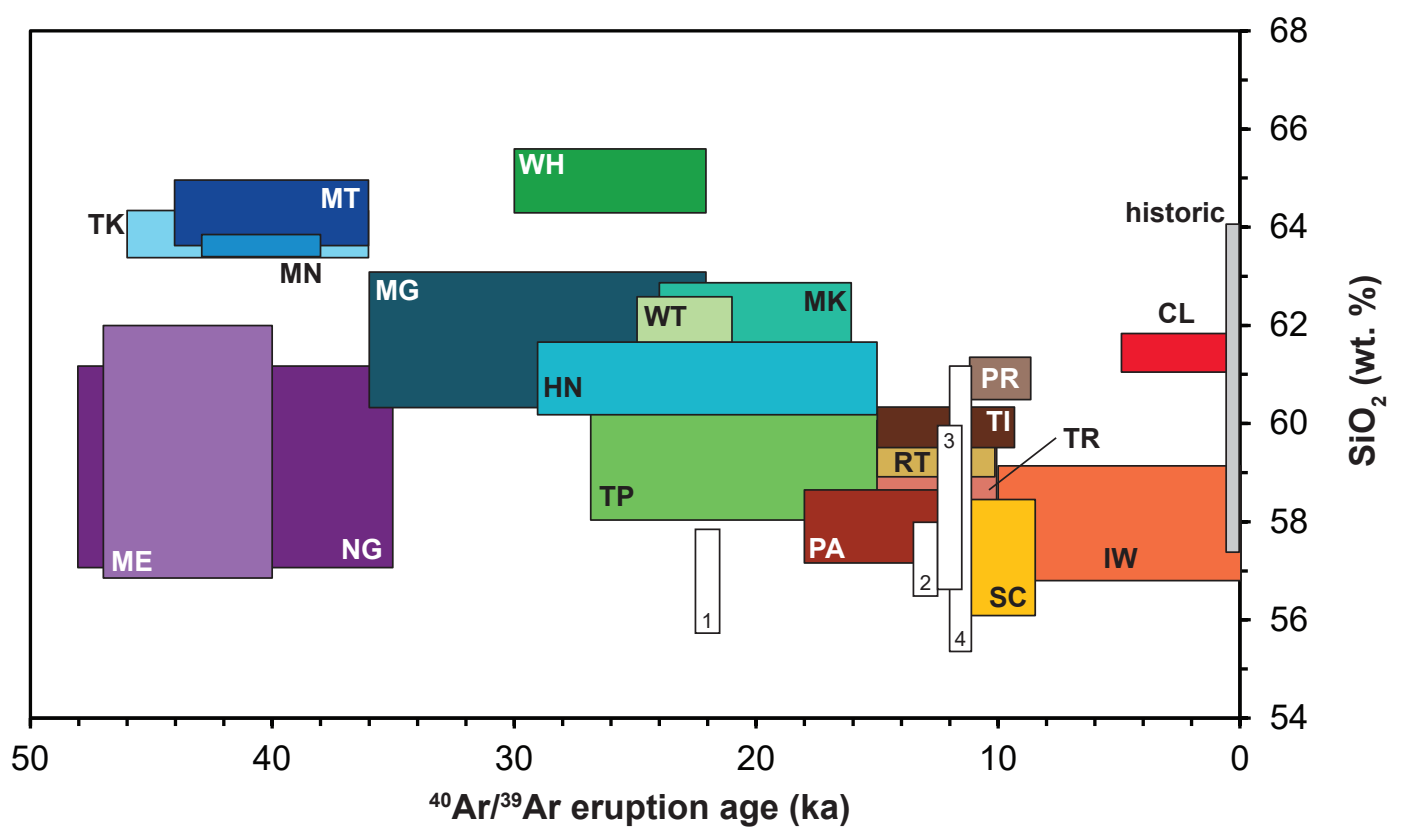

CL Crater Lake ( $<5 \mathrm{ka})$

IW Iwikau (<10 ka)

PR Pinnacle Ridge ( 10 ka)

SC Saddle Cone ( 10 ka)

TI Tureiti ( 12 ka)

PT Paretetaitonga ( 15 ka)

RT Rangataua (15-10 ka)
TR Turoa (17-10 ka)

MK Makotuku (24-16 ka)

WT Waitonga ( 23 ka)

TP Te Piripiri (27-16 ka)

HN Horonuku (29-16 ka)

WH Whakapapaiti ( 26 ka)
MG Manganuioteao (30-22 ka)

TK Te Kohatu (44-36 ka)

MN Mananui ( 40 ka)

MT Mangaturuturu (46-36 ka)

ME Mangaehuehu (47-40 ka)

NG Ngahuinga (48-35 ka) 

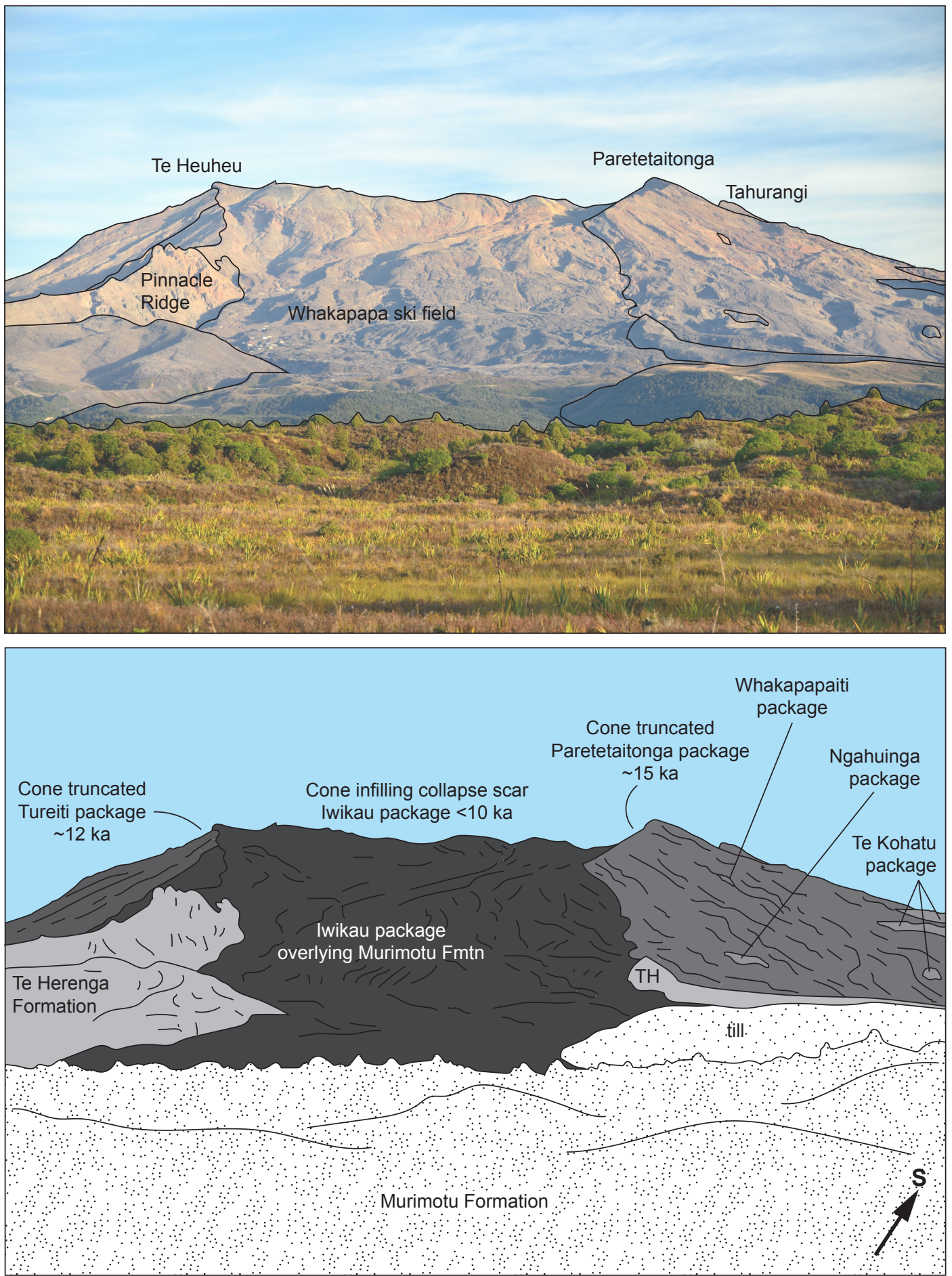